
OUTCOMES FOR PERSONS AFTER STROKE IN LATVIA AND SWEDEN

Doctoral Thesis for obtaining the degree of a Doctor of Medicine Speciality - Physical and Rehabilitation Medicine 


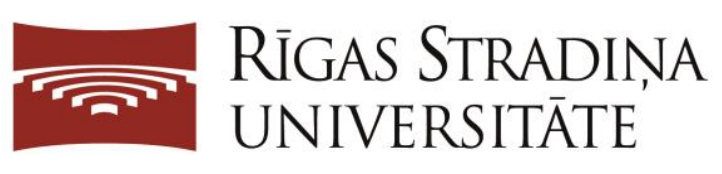

Guna Bērziņa

\title{
COMPARISON OF REHABILITATION OUTCOMES FOR PERSONS AFTER STROKE IN LATVIA AND SWEDEN
}

\author{
Doctoral Thesis \\ for obtaining the degree of a Doctor of Medicine \\ Speciality - Physical and Rehabilitation Medicine
}

Supervisors:

Dr. med., Associate Professor Anita Vētra (Rīga Stradiņš University)

Dr. med., Professor Katharina Stibrant Sunnerhagen

(Institute of Neuroscience and Physiology, University of Gothenburg) 


\section{ANNOTATION}

Stroke is one of the most common causes of long-term disability that leads to substantial economic and social burden for individuals, families, communities and nations. Rehabilitation aims to improve person's functioning and decrease adverse consequences of stroke in all levels. Therefore, defining an optimal model of stroke care is in the interests of patients, health professionals, researchers and policymakers. One of the ways towards it is by investigating and comparing the outcomes of the stroke care systems currently in use.

The aim of this thesis was to explore the determinants of rehabilitation outcomes for persons after stroke and to compare them between those living in Latvia or in Sweden, using the bio-psycho-social model suggested by World Health Organization (WHO).

This project was organized in four parts. Part 1 focused on comparison between two in-patient rehabilitation systems and the differences in level of independence at discharge from rehabilitation between two cohorts were compared in 1055 and 1748 persons after stroke, living in Latvia and Sweden, respectively. For all following parts of this research work, cross-sectional study design was used. In Part 2, the influence of dependence level at discharge from rehabilitation on self-perceived disability in chronic phase of stroke was investigated in 255 persons from Latvia. Part 3 explored personal factors' (age, gender, place of residence and time since onset of stroke) role in perception of functional limitations, barriers and facilitators in 243 persons living in Sweden. The relevance of the same factors in persons after stroke living in Latvia was evaluated in Part 4. Functional Independence Measure, International Classification of Functioning, Disability and Health Core Set for stroke and World Health Organization Disability Assessment Schedule 2.0 were used for outcome assessment. Socio-demographic and medical data, as well as information on organisational aspects of rehabilitation were also used as variables. Both theoretical as well as statistical analyses were used to compare rehabilitation systems in Latvia and Sweden. Appropriate regression analyses were used in all parts of this work.

It seems that the components of stroke care are similar in rehabilitation systems in Latvia and Sweden. However, both populations vary in their basic medical and sociodemographic characteristics, as well as in the level of independence at admittance and discharge. There are also potential differences in the content and organizational aspects of rehabilitation. The levels of independence in daily activities at discharge from rehabilitation are significant factors that influenced perception of disability in the chronic phase of stroke.

Personal factors such as age, gender, place of residence and time since onset of stroke can influence self-perceived functioning and environmental factors, as defined in the 
framework of the ICF, in persons living in Sweden. Same factors were also significant in the model that evaluated problems in 'Activities and Participation' persons living in Latvia. However, the role of those factors where rather small in both populations.

Thus, the results of this thesis shows that different aspects of WHO's suggested biopsycho-social model influence rehabilitation outcomes for persons after stroke and results depends on the country of residence (Latvia or Sweden). Functional, organizational, social and personal factors are of importance. Some of the factors are modifiable by the healthcare system, but some are the responsibility of society as a whole. 


\begin{abstract}
ANOTĀCIJA
Insults ir viens no visbiežāk sastopamiem ilgstošas invaliditātes iemesliem pieaugušo populācijāa Tas rada ievērojamas ekonomiskas un sociālas problēmas indivīdiem, vinuu gímenēm, sabiedrībām un nācijām. Rehabilitācijas mērķis ir uzlabot personas funkcionēšanu un mazināt insulta nelabvēlīgās sekas jebkurā aprūpes līmen̄̄. Šì iemesla dēl gan pacientu, gan veselības aprūpes profesionāḷ, kā arī pētnieku un politiķu interesēs ir atrast optimālu insulta aprūpes modeli. Viens no veidiem, kā šim modelim tuvoties, ir izpētît un salīdzināt insulta aprūpes iznākumus, kas tiek izmantoti šobrīd.

Šì darba mērķis bija salīdzināt rehabilitācijas rezultātus personām pēc insulta Latvijā un Zviedrijā, izmantojot Pasaules Veselības organizācijas ieteikto biopsihosociālo modeli.

Šis darbs sastāv no četrām daļām. Pirmajā pētījuma daḷā ir veikts divu stacionārās rehabilitācijas sistēmu (Latvijas un Zviedrijas) salīdzinājums, kā arī salīdzinātas neatkarības līmeṇa atšķirības rehabilitācijas beigās starp divām grupām - 1055 Latvijā dzīvojošām un 1784 Zviedrijā dzīvojošām personām pēc insulta. Pārējām pētījuma daḷām tika izmantots šķērsgriezuma pētījuma dizains. Otrajā dạ̦ā tika pētīta neatkarības līmeņa - rehabilitācijas kursa beigās - ietekme uz personu vērtējumu par viṇu invaliditātes pakāpi hroniskā insulta fāzē 255 personām no Latvijas. Trešajā daḷā tika pētīta personālo faktoru (vecuma, dzimuma, dzīvesvietas un laika kopš insulta) loma, nosakot 243 Zviedrijā dzīvojošu personu vērtējumu par funkcionēšanas ierobežojumiem, kā arī vides faktoru kavētājiem un veicinātājiem. Šo pašu faktoru nozīme Latvijā dzīvojošām personām pēc insulta tika vērtēta pêtījuma ceturtajā daļā. Kā iznākuma novērtēšanas instrumenti tika izmantoti: Funkcionālās neatkarības mērījums, Starptautiskās funkcionēšanas, nespējas un veselības klasifikācijas (SFK) insulta pamatkopa un Pasaules Veselības organizācijas Invaliditātes novērtēšanas saraksta 2. versija. Kā main̄̄gie tika izmantoti sociodemogrāfiskie un medicīniskie dati, kāar āi informācija par rehabilitācijas organizatoriskajiem aspektiem. Tika veikts gan teorētisks, gan statistisks salīdzinājums starp Latvijas un Zviedrijas rehabilitācijas sistēmām. Atbilstošas regresijas analīzes tika veiktas visās šī pētījuma daḷās.

Latvijas un Zviedrijas sistēmās insulta aprūpes komponenti šķiet līdzīgi. Tomēr abas populācijas atšķiras ar pamata medicīniskajiem rādītājiem, sociodemogrāfisko raksturojumu un neatkarības līmeni rehabilitācijas sākumā un beigās. Iespējams, ka tās savā starpā atšķkiras arī ar rehabilitācijas saturu un organizatoriskajiem aspektiem. Neatkarības līmenis ikdienas aktivitāšu veikšanā rehabilitācijas kursa beigās ir nozīmīgs faktors, kas ietekmē personas vērtējumu par viṇa invaliditātes līmeni hroniskā insulta fāzē.
\end{abstract}


Tādi personālie faktori kā vecums, dzimums, dzīvesvieta un laiks kopš insulta ietekmē Zviedrijā dzīvojošu personu vērtējumu par funkcionēšanu un vides faktoriem atbilstoši SFK konceptam. Šie paši faktori, novērtēti "aktivitāšu un līdzdalības" domēnā, bija nozīmīgi arī Latvijas populācijā. Tomēr šo faktoru loma abās populācijās bija diezgan maza. Šì darba rezultāti apstiprina, ka dažādi Pasaules Veselības organizācijas ieteiktā biopsihosociālā modeḷa aspekti ietekmē rehabilitācijas rezultātus personām pēc insulta, turklāt tie atšksiras atkarībā no valsts, kurā persona dzīvo (Latvijā vai Zviedrijā). Svarīgi ir gan funkcionālie, gan sociālie, gan personālie faktori. Dažus no šiem faktoriem var ietekmēt, izmantojot veselības aprūpes sistēmu, bet citi ir visas sabiedrības atbildība. 


\section{CONTENTS}

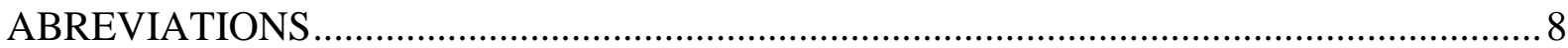

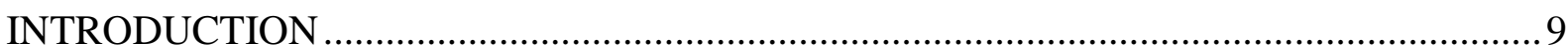

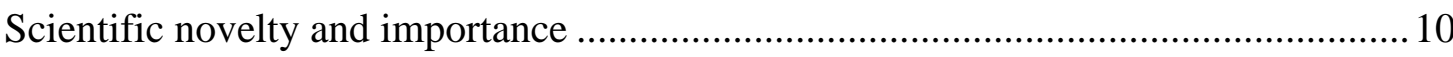

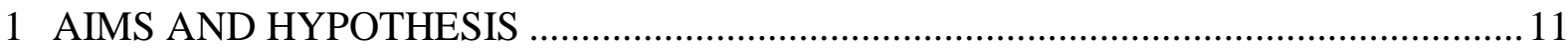

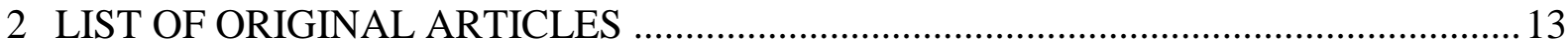

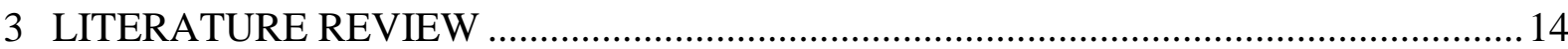

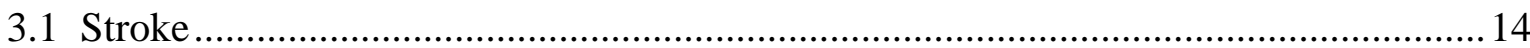

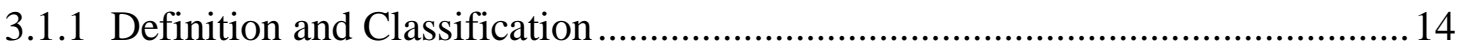

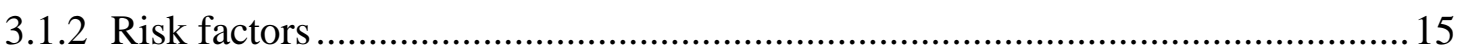

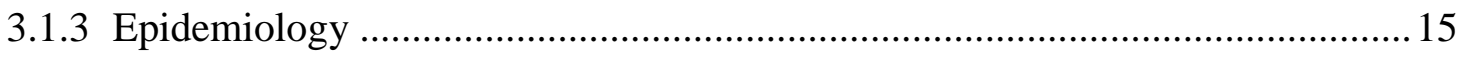

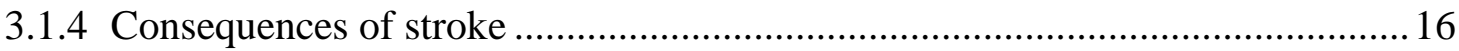

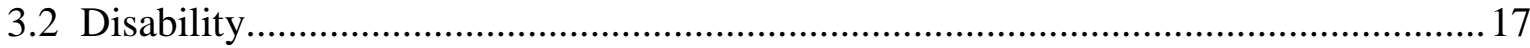

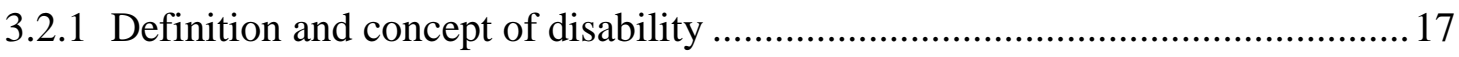

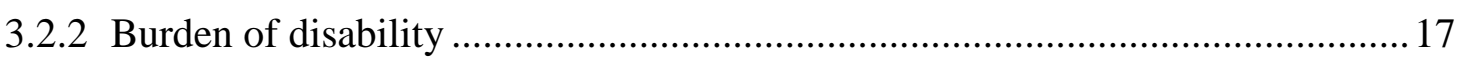

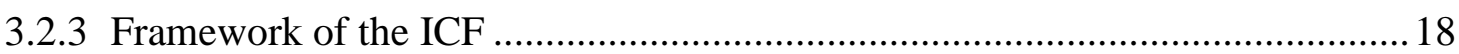

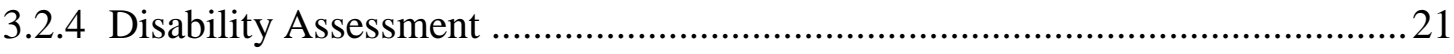

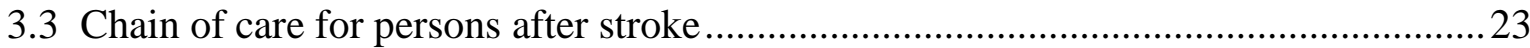

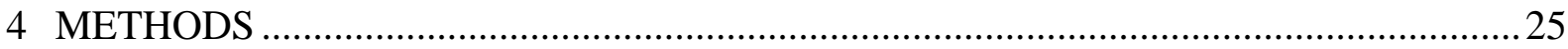

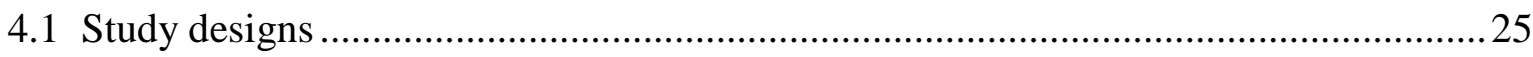

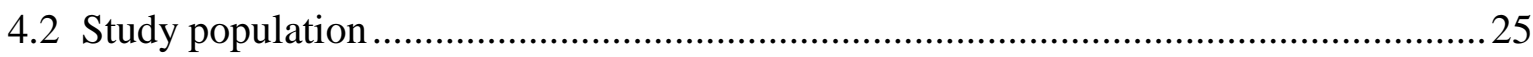

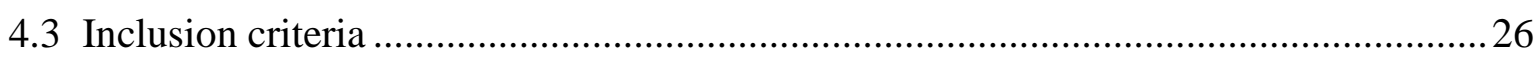

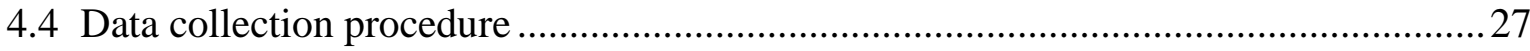

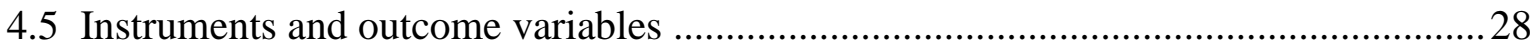

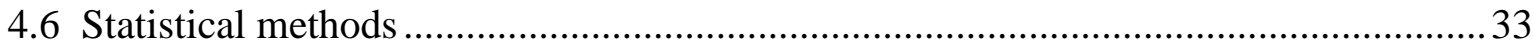

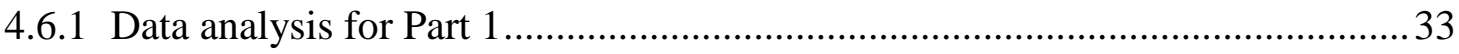

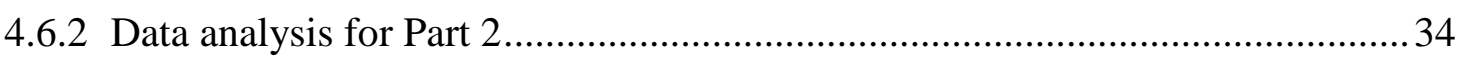

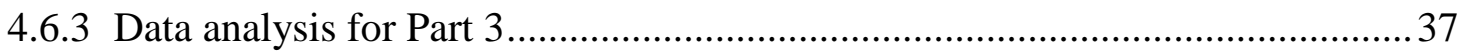

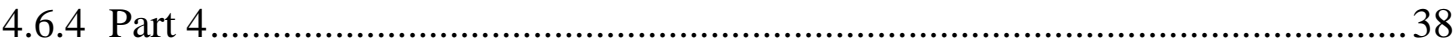

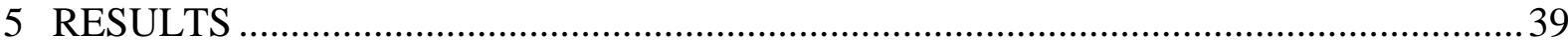

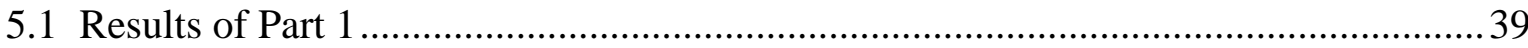

5.1.1 Organization of rehabilitation - qualitative comparison between populations .. 39

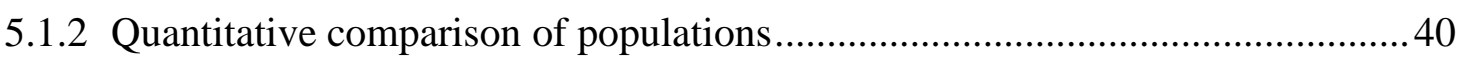

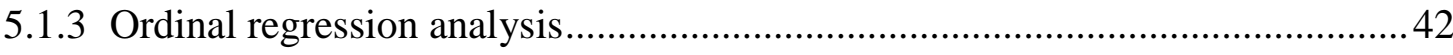




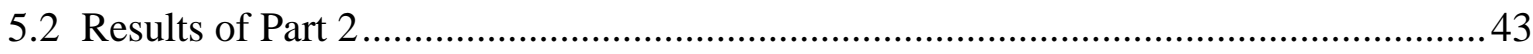

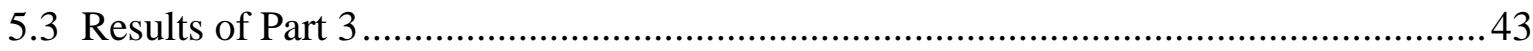

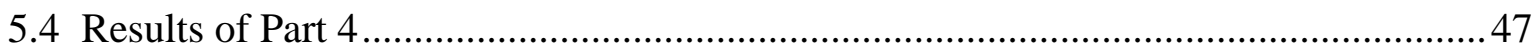

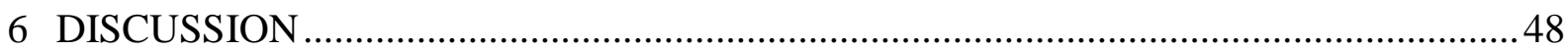

6.1 Functional outcomes of in-patient rehabilitation after stroke in

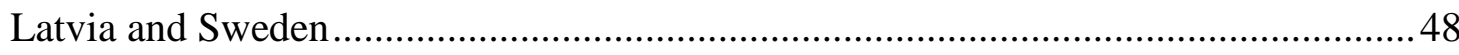

6.1.1 Differences in two stroke care systems ..........................................................48

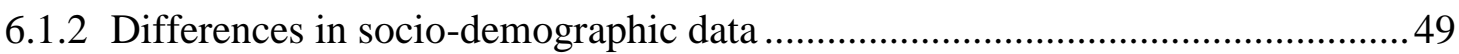

6.1.3 Differences in functional dependence at the discharge ..................................50

6.2 Self-perceived level of disability in Latvian population.............................................50

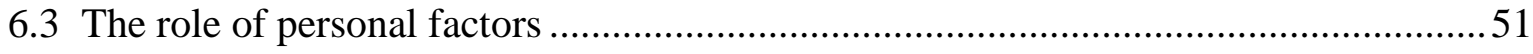

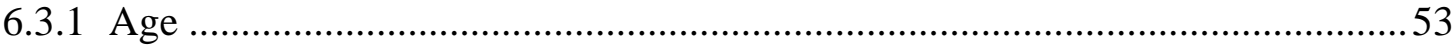

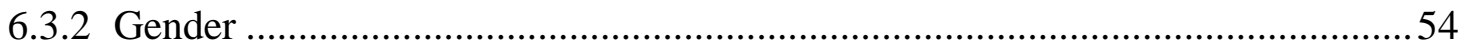

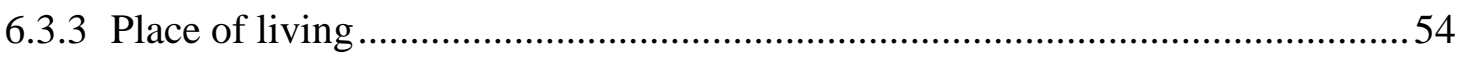

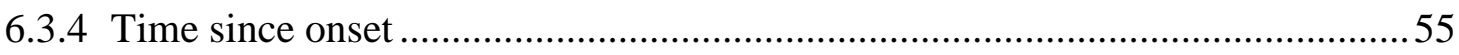

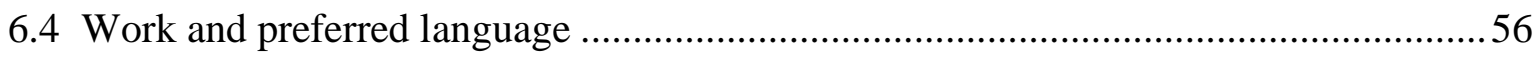

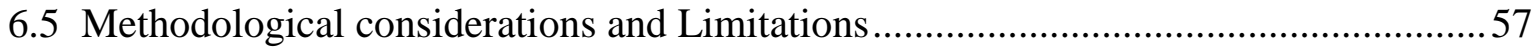

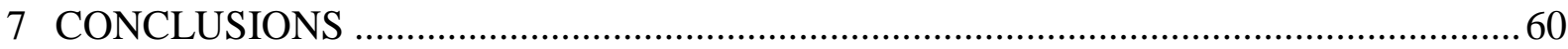

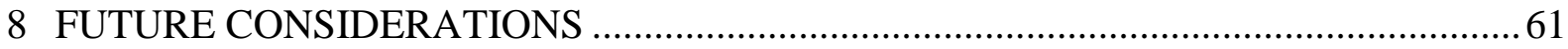

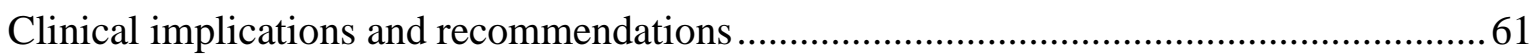

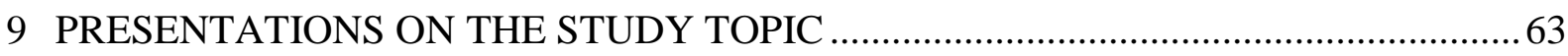

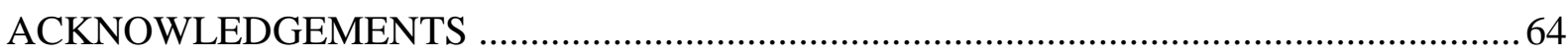

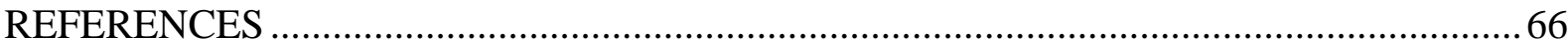

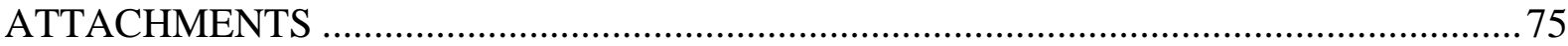




\section{ABREVIATIONS}

FIM

ICD-10

ICF

ICIDH

mRS

WHO

WHODAS 2.0
Functional Independence Measure

International Classification of Diseases, 10th version

International Classification of Functioning, Disability and Health

International Classification of Impairments, Disabilities and Handicaps

Modified Rankin Scale

World Health Organization

World Health Organizations Disability Assessment Schedule 2.0 


\section{INTRODUCTION}

Despite increasing focus on evidence-based primary and secondary prevention, stroke still occurs. The lifetime risk for stroke to occur is in 1 of 6 persons worldwide as reported by the World Stroke Organization. (Seshadri et al., 2006) In addition, to being major cause of death, stroke is the most common cause for disability in the adult population. (Mackay et al, 2004, WHO STEPS stroke manual, 2006) Even with optimal acute care, less than one in 3 patients fully recovers from stroke. (Hacke et al., 2004) World Health Organization (WHO) predicts that there will continue to be large increase in non-communicable diseases (including stroke) related to years lived with disability in rapidly developing regions. (World Report on Disability, 2011)

In order to provide a universal language understood by health professionals, researchers, policymakers, patients and patient organizations, as well as ensure comprehensive framework of care, International Classification of Functioning, Disability and Health (ICF) was developed and approved of in 2001. (S. Geyh et al., 2004; International Classification of Functioning, Disability and Health, 2001) ICF, defines disability as the umbrella term for impairments, activity limitations and participation restrictions, referring to the negative aspects of interaction between and individual and that individual's contextual factors (environmental and personal). It is called a "bio-psycho-social model" of disability. (World Report on Disability, 2011)

WHO emphasizes that disability is a part of human condition, which is complex and dynamic interaction between health condition and contextual factors. It is a cause for economic and social burdens for individuals, families, communities and nations. WHO reports prevalence of disability being $15 \%$ of world's population, as well as underlines its relation to human rights and developmental (social and political) issues that leads to increased direct and indirect costs. (World Report on Disability, 2011)

Rehabilitation is a tool that addresses the issue of disability. It is aiming to improve person's independent living, as much as possible, through minimizing negative effects of stroke and/or enabling adaptation strategies. (PRM, Section of UEMS, 2006; Quinn et al., 2009b) Rehabilitation should start as soon as possible after an event, such as stroke, and continue as long as necessary even when person has already returned to his/her customary environment in community. (A. Ward et al., 2012) The content of the rehabilitation varies depending on the time since the stroke (acutely, sub-acutely or in the later phases) as well on organisational factors. (Gutenbrunner et al., 2010; A. Ward et al., 2012) The recommenddations on structure of rehabilitation organization provide the theoretical continuity of 
rehabilitation. The rehabilitation phase between early rehabilitation in acute setting and community based follow-up rehabilitation is defined as post-acute rehabilitation. It is goaloriented and multi-professional in- or outpatient rehabilitation service and based on patients' needs. (A. Ward et al., 2012) However, these inclusion criteria for patients' selection are suggested, not internationally accepted. (A. B. Ward et al., 2010) The availability and effectiveness of rehabilitation services in different countries varies depending on local policy and available resources. (De Wit et al., 2007; Putman and De Wit, 2009) However, the comparison of the systems and outcomes would provide a knowledge that guides towards more optimal stroke care.

In the development of specialized stroke care units during 1970s, Sweden has been among the pioneers. In addition, this process and the outcomes have been well documented. In Latvia similar approach of stroke care was adapted approximately 25 years later. Unfortunately, there is only one publication available that describes experiences of stroke survivors in Riga. (McKevitt et al., 2003)

\section{Scientific novelty and importance}

This research adds knowledge on outcomes of stroke rehabilitation in two European countries (Latvia and Sweden) and differences between them. The evaluation and comparison between outcomes after stroke, both, after specialised in-patient rehabilitation and in a longterm perspective, is important for improving the process of continuous care after stroke and for adequate planning and involvement of services needed. That is in line with the World Stroke Organization Global Stroke Services Guidelines and Action Plan. The study also highlights the problems of this approach.

In this thesis, the results of specialised inpatient rehabilitation are treated as complex intervention and analysed accordingly, also taking into account the significance of other related factors. Moreover, it is based on clinical data from daily practice, thus representing the outcomes of two systems that are currently in use. In the statistical analysis, the ordinal approach to the data has been used and shift analysis has been done as a part of statistical analysis. That is in line with the main assumptions and up to date approach for analysis of functional outcomes. This has not been presented in rehabilitation research before.

The self-perceived disability is used as another outcome in this work. This concept has received little interest in the field of research. However, restrictions and limitations that a person experiences in everyday life due to the consequences of stroke, is important in determination of care needs and in planning interventions. Therefore, this research work focuses on systemic issues of care after stroke, rather than individual effectiveness of rehabilitation. 


\section{AIMS AND HYPOTHESIS}

The aim of the theses was to explore the determinants of rehabilitation outcomes for persons after stroke and compare them between those who lives in Latvia and Sweden, using the bio-psycho-social model suggested by World Health Organization.

\section{$\underline{\text { Tasks: }}$}

- To compare available information on Latvian and Swedish in-patient rehabilitation systems.

- To compare the characteristics and functional independence at admittance and discharge of populations that has received in-patient rehabilitation in Latvia and Sweden.

- To explore the impact of possible differences on functional independence for persons after stroke.

- To investigate whether functional limitations in the post-acute phase of stroke (at the time of inpatient rehabilitation) have an influence on self-perceived level of disability in the late phase of stroke in a Latvian population living in the society (at home).

- To investigate the role of social and personal factors in explaining the selfperceived level of disability in the chronic phase of stroke in persons living Latvia.

- To investigate whether such personal factors as age, gender, place of living and time since onset has a predictive value for functioning and environmental factors in chronic phase of stroke for persons living in Sweden.

- To investigate whether there are relationships between personal factors as mentioned above and certain categories of functioning and environmental factors for persons living in Sweden.

- To explore how these personal factors interact to influence self-perceived functional outcome and perception of environmental factors as barriers or facilitators in persons, living in Sweden.

- To explore if personal factors identified to be important in a Swedish population, are also relevant for a Latvian population of stroke survivors 


\section{General hypothesis:}

Different aspects of WHO's suggested bio-psycho-social model will influence rehabilitation outcome for persons after stroke and the results will depend on country of residence (Latvia or Sweden). 


\section{LIST OF ORIGINAL ARTICLES}

The thesis is based on following studies:

1. Guna Bērziņa, Anita Vētra, Katharina Stibrant Sunnerhagen. A comparison of stroke rehabilitation; data from two national cohorts. Acta Neurologica Scandinavica. Article first published online: 15 December 2015 (See Attachment 1)

2. Guna Bērziņa, Baiba Smilškalne, Anita Vētra, Katharina Stibrant Sunnerhagen. Living in Latvia after stroke; the influence of functional, social and personal factors on the level of self/perceived disability. BMJ Open 24 June 2016; 6(6). (See Attachment 2)

3. Guna Berzina, Markku Paanalahti, Åsa Lundgren-Nilson, Katharina Stibrant Sunnerhagen. Exploration of some personal factors of the International Classification of Functioning, Disability and Health Core sets for stroke. Journal of Rehabilitation Medicine, 2013; 45: 609-615. (See attachment 3) 


\section{LITERATURE REVIEW}

\subsection{Stroke}

\subsubsection{Definition and Classification}

Stroke is defined by the World Health Organization (WHO) as "a clinical condition consisting of rapidly developing clinical signs of focal (or global in case of coma) disturbance of cerebral function lasting more than 24 hours or leading to death with no apparent cause other than a vascular origin". The outcome of this sudden or at least rapid onset condition corresponds to involvement of focal areas in the brain. (WHO Task Force on Stroke and Other Cerebrovascular Disorders, 1989)

"Stroke" is useful term for general description of events secondary to cerebrovascular disease, but it is not specific enough to use as a formal medical diagnosis. (DeLisa et al. 2005) It requires examination of a physician and confirmation by computer tomography, After this, the background of the stroke is explored (DeLisa et al. 2005) and diagnostic codes I60 - I69 in International Classification of Diseases $10^{\text {th }}$ version (ICD-10) are used. (International Classification of Diseases and Related Health Problems, 2010) These diagnoses of stroke essentially are divided in two broad categories, according to nature of cerebral lesion. (WHO Task Force on Stroke and Other Cerebrovascular Disorders,1989)

- As a result of temporary or permanent occlusion of feeding artery, extracranially or intracranially, or (more rarely) of venous thrombosis - cerebral infarction (WHO Task Force on Stroke and Other Cerebrovascular Disorders, 1989) (Code I63 in the ICD-10 (International Classification of Diseases and Related Health Problems, 2010))

- As a result of the rupture of an abnormal artery (aneurysm or arteriovenous malformation) or arteriole in the brain parenchyma - intracerebral haemorrhage (I61 in the ICD-10) or within the dural space - subarachnoid haemorrhage (I60 in the ICD-10). (Braddom et al., 2011; WHO Task Force on Stroke and Other Cerebrovascular Disorders, 1989) About 20\% of all strokes occur due to haemorrhage. (Steiner et al., 2006) 


\subsubsection{Risk factors}

Probability of getting a stroke is clearly influenced by the presence of risk factors. (WHO Task Force on Stroke and Other Cerebrovascular Disorders, 1989; Norrving, 2014). There are five known main risk factors (i.e. hypertension, current smoking, abdominal obesity, diet and low physical activity) that are modifiable and account for more than $80 \%$ of the global risk factors of all strokes. (O'Donnell et al., 2010) With the addition of five other risk factors (alcohol intake, psychosocial stress, depression, cardiac causes and higher ratio between apolipoproteins A and B), the Population-attributable risk for all stroke rise to $90 \%$. (O'Donnell et al., 2010) All these risk factors are more prevalent in high-income countries. (Yusuf et al., 2014) A reduction of known risk factors is an important step in preventing stroke. (WHO Task Force on Stroke and Other Cerebrovascular Disorders, 1989; European Stroke Organization, 2008) However, the presence of any single risk factor or combination of risk factors in itself does not predict occurrence of stroke; conversely, the absence of any known stroke risk factors does not ensure that stroke will not occur. (WHO Task Force on Stroke and Other Cerebrovascular Disorders, 1989)

\subsubsection{Epidemiology}

Despite increasing focus of evidence-based primary and secondary prevention, stroke still occurs. (Quinn et al., 2009b) In addition, to being major cause of death, stroke is the most common cause for disability in the adult population. (Mackay et al, 2004, WHO STEPS stroke manual, 2006)

Approximately 15 million people suffer a stroke annually (Strong et al., 2007; Mackay et al, 2004) and one third of them die. (Feigin et al, 2014) It is a second leading cause of mortality (5.5 million deaths annually) after ischemic heart disease (7.2 million deaths annually) (Mukherjee and Patil, 2011) and it accounts approximately for $10 \%$ of all deaths both, worldwide and in Europe. (Nichols et al., 2014; Nichols M, 2012; Strong et al., 2007) Fatality rates due to stroke are higher in middle- and low-income countries. (Yusuf et al., 2014) However, according to statistics of WHO, mortality rates varies greatly in European countries, from 27 in Switzerland and 39 in Sweden to 154 in Latvia and even 228 Russia and 249 in Kyrgyzstan per 100000 in 2004. (WHO Global Infobase, 2015) According to the latest data, the mortality proportions between countries seem to be remained similar. (Nichols $\mathrm{M}$, 2012) 
As in most European countries, stroke along with other cardiovascular diseases is one of the leading causes of mortality in Latvia as well as in Sweden. (Noncommunicable Diseases. Country profiles 2014, 2014) It has been estimated that, although decreasing, mortality after stroke in Latvia remains the one of highest in the European Union. Sweden, on contrary, is between leading countries in both, fewer deaths and less disability-adjusted life years lost due to stroke. (Nichols et al., 2014; Nichols M, 2012)

Estimated prevalence of stroke survivors globally is 62 million. (Mukherjee and Patil, 2011) Moreover, there is predicted increase of stroke frequency along with other noncommunicable diseases in future, especially in rapidly developing countries. (Ovbiagele et al., 2013; World Report on Disability, 2011)

\subsubsection{Consequences of stroke}

Even with optimal acute care, less than one in three patients fully recovers from stroke. (Hacke et al., 2004) Clinical features of a stroke depend on the location and extent of the lesion. (Norrving,2014) Besides definite clinical signs of a stroke, such as unilateral or bilateral motor and sensor impairment, aphasia, hemianopia, diplopia, forced gaze, apraxia, ataxia perception deficit of acute onset that can combine with dysarthria, impaired cognitive functions, dysphagia or other signs (WHO STEPS stroke manual, 2006) one can also experience series of restrictions in activities and participations. (Alguren et al., 2010) Approximately half of the survivors' live with restrictions in daily life. (Alguren et al., 2010; Skolarus et al. 2014; Mackay, 2004) Capacity and performance of activities can be altered (Alguren et al. 2010) and the person could discover new barriers in one's environment. (Alguren et al., 2009; Rochette et al., 2001) All these consequences often results in reduced independence. (Glassel et al., 2012; Vincent et al., 2009) The situation the person is stuck in often requires help from family members, health systems or other social institutions. (Alguren et al., 2009; Vincent et al., 2009; WHO STEPS stroke manual, 2006) Individual limitations and restrictions from a stroke depend on the context, such as access to support and the environment (both individual and social), as well as these persons' subjective views and roles in society. (Bouffioulx et al., 2011; International Classification of Functioning, Disability and Health, 2001, World Report on Disability, 2011) Therefore, stroke is one of the most common causes of disability (World Report on Disability, 2011, Nichols et al., 2013, Mukherjee and Patil, 2011) and thus, one of the most prominent non-communicable health problems (World Health Statistics 2014, 2014), especially in European countries. (Lopez et al., 2006; Vos et al., 


\subsection{Disability}

\subsubsection{Definition and concept of disability}

Disability is the umbrella term for impairments, activity limitations and participation restrictions referring to the negative aspects of interaction between an individual and that individual's context. (Leonardi et al., 2006) It is part of human condition, which is a complex and dynamic interaction between health condition and contextual factors. The WHO reports that the prevalence of disability is $15 \%$ of world's population, as well as underlines its relation to human rights and developmental (social and political) issues. Disability leads to increased direct and indirect costs. However, the true picture of disability remains rather a challenge. (World Report on Disability, 2011)

There have been different conceptualizations of disability (medical and social models, biopsychosocial, charity and human rights approaches). The medical model of disability "views disability as a problem of person, directly caused by disease, trauma or other health condition, which requires medical care provided in the form of individual treatment by professionals" (medical care is central activity to be monitored and enhanced). The social model, developed as response to the medical model, clearly differentiates between impairment and disability and considers the latter a "socially created problem" that "is not an attributable of an individual, but rather a complex collection of conditions, many of which are created by social environment". (Alves et al., 2012) The "charity" approach - people with disabilities are viewed as a victims of impairments and beneficiaries of charity (low decision making capacity). (Alves et al., 2012) The WHO relies on an integrated model of disability, which is called the bio-psycho-social model and merges both. (Quintas et al., 2012)

\subsubsection{Burden of disability}

Poverty leads to stroke and stroke leads to poverty. Therefore disability caused by a stroke is of interest from ethical and political, as well as local and global perspectives. (World Report on Disability, 2011)

In general, persons with disabilities experience poorer health outcomes, lower educational achievements, less economic participation, higher rates of poverty and increased dependency and restricted participation. The risk of worse social and economic well being is higher for persons living with disability. (World Report on Disability, 2011) They are more likely to be subjects of violation of equality, dignity and autonomy. To address these ethical issues, the Convention on the Rights of Persons with Disabilities has been presented. ( The 
Convention on the Rights of Persons with Disabilities, 2006) The Global Bill of Rights Working Group also underlines the aspects in care that are important for persons after stroke and their caregivers, for the best possible outcomes. (Damrow et al., 2014)

Disability due to stroke causes complex and long-term emotional and financial burdens for persons, their families and community. (Carod-Artal and Egido, 2009; CatalinaRomero et al., 2015; Kankeu et al., 2013; Lopez et al., 2006; Mukherjee and Patil, 2011; Vos et al., 2012; Walsh et al., 2014) Between other things, post-stroke disability creates a risk for worse health outcomes. (Carod-Artal and Egido, 2009) Stroke also plays an important role on global burden of diseases, especially in the European countries. (Lopez et al., 2006; Vos et al., 2012) Stroke is related to remarkable costs, especially the ones related directly to healthcare. (Gustavsson et al., 2011) However, the costs related to direct non-medical costs, such as social services, special accommodation and informal care (Persson et al., 2012), as well as indirect costs (i.e. lost production due to work absence or early retirement)(Ghatnekar et al., 2014)are also of importance. (Gustavsson et al., 2011) Therefore, disability after stroke is also a developmental issue (Barnes C, 2010) and rehabilitation is a tool that addresses the issue. (Gutenbrunner et al., 2015)

\subsubsection{Framework of the ICF}

The "bio-psycho-social" model of disability is at the heart of conceptual framework of the International Classification of Functioning, Disability and Health (ICF). (International Classification of Functioning, Disability and Health, 2001) In this framework different perspectives on health and disability is integrated: biologic, individual and social (Quintas et al., 2012) and represents the interaction of an individual with his/her health condition and his/her environment. (Colombetti et al., 2012) The overall concept of the ICF is showed in Figure 3.1 .

The ICF was approved by the WHO in Geneva in 2001. This classification was developed on the basis of the International Classification of Impairments, Disabilities and Handicaps (ICIDH), published in 1980. (International Classification of Impairments, Disabilities and Handicaps, 1980) The main objectives of the ICF are to provide a universal language understood by health professionals, researchers, policymakers, patients and patient organizations and ensure comprehensive framework for care. (S. Geyh et al., 2004)

The ICF consists of two parts, each with two components:

1. Functioning (or Health-related functioning (Salvador-Carulla and GarciaGutierrez, 2011)) and Disability: 
a. 'Body Functions' (the physiological functions of body systems (including psychological functions) and 'Body Structures' (anatomical parts of the body such as organs, limbs and their components)

b. 'Activity' (execution of a task or action by an individual) and 'Participation' (involvement in a life situation)

2. Contextual Factors:

a. 'Environmental Factors' - make up the physical, social and attitudinal environment in which people live and conduct their lives

b. 'Personal Factors' - the particular background of an individual's life and living, which comprise features of individual that are not part of health condition or health states such as gender, lifestyle, coping styles, education, past and current experience etc. (International Classification of Functioning, Disability and Health, 2001)

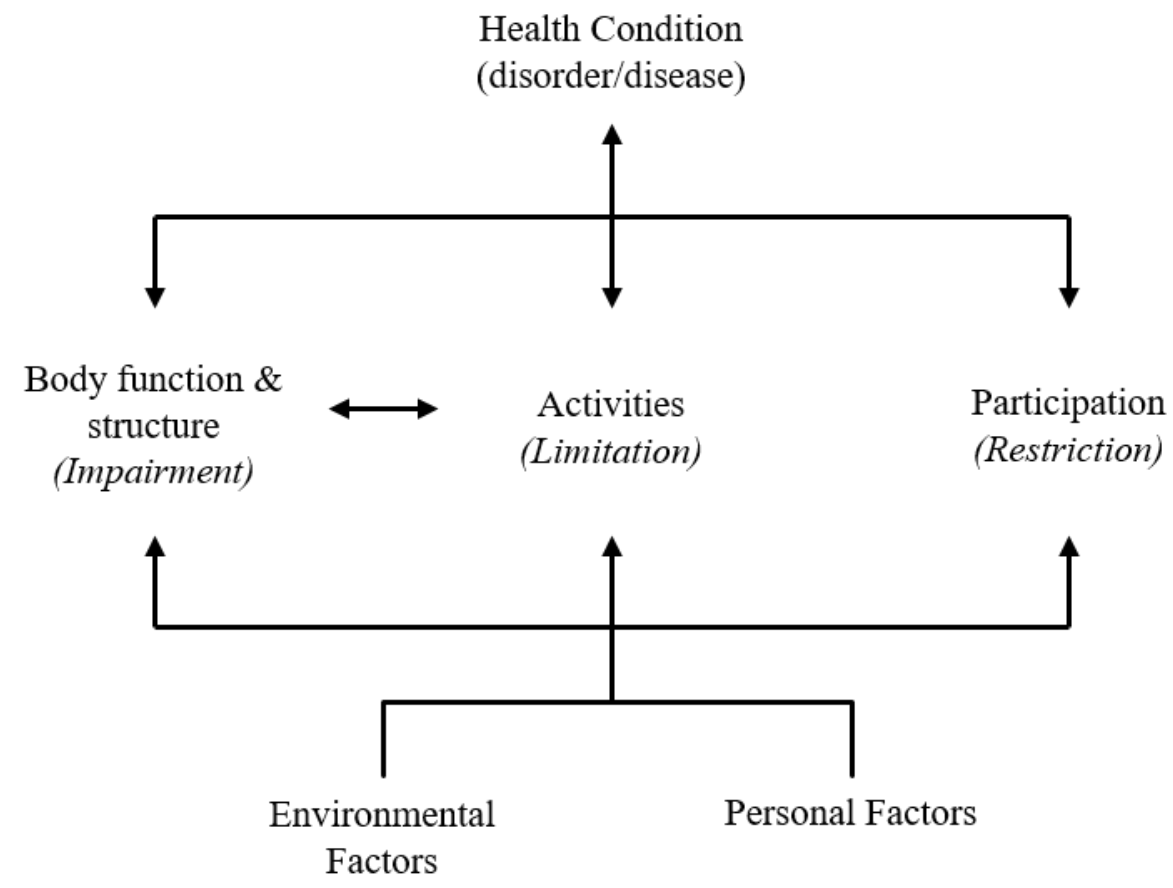

Figure 3.1 The concept of the ICF (International Classification of Functioning,

Disability and Health, 2001)

The ICF is organized in hierarchical code system where each of the components is divided in categories that represent the units of the ICF and is divided within chapters and, further, individual second-, third-, or forth-level categories. (Bostan et al., 2012) The organisation of the structure is showed in Figure 3.2. 


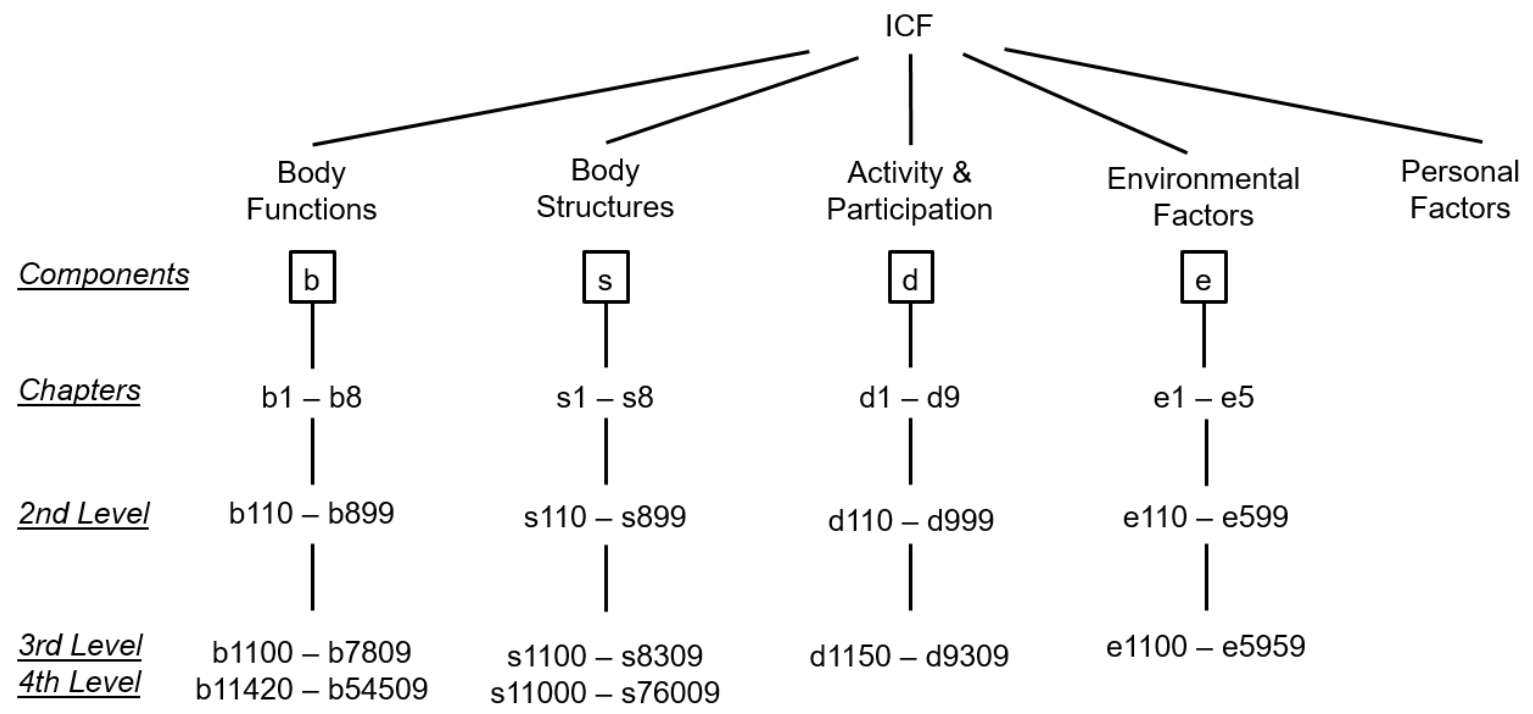

Figure 3.2 Coding system of the ICF

(International Classification of Functioning, Disability and Health, 2001)

For describing the severity of problem, the qualifiers should accompany each code. Qualifiers are coded as one or more numbers after a point and are interpreted depending of the level of problem. (International Classification of Functioning, Disability and Health, 2001) Description of qualifiers is given in Table 3.1.

Table 3.1

\section{Descriptions of ICF qualifiers}

\begin{tabular}{l|l|l} 
xxx.0 & No problem (none, absent, neligible,...) & $0-4 \%$ \\
\hline xxx.1 & MILD problem (slight, low,...) & $5-24 \%$ \\
\hline xxx.2 & MODERATE problem (medium, fair,...) & $25-49 \%$ \\
\hline xxx.3 & SEVERE problem (high, extreme,...) & $50-95 \%$ \\
\hline xxx.4 & COMPLETE problem (total,...) & $96-100 \%$ \\
\hline xxx.8 & not specified & \\
\hline xxx.9 & not applicable &
\end{tabular}

There are two separate qualifiers for component of 'Activities and Participation': The performance qualifier (describes what an individual does in his or her current environment) and the capacity qualifier (describes an individual's ability to execute a task or an action). Environmental factors can have positive or negative influence on the person's functioning. For barriers, qualifiers are used the same $(0-4)$ scale, but to denote facilitator the point (that is used in case of barriers) is replaced with plus sign. (International Classification of Functioning, Disability and Health, 2001) 
In total, the ICF consists of 1424 items. (International Classification of Functioning, Disability and Health, 2001) To improve clinical practicability, Brief and Comprehensive ICF Core Sets have been developed. This process has been based on previous evidence as well as formal decision making and consensus process. (Cieza et al., 2004) Therefore, ICF Core Sets represent a selection of ICF categories describing the prototypical spectrum of problems in the functioning of patients with specific health conditions (Cieza et al., 2004), including ICF Core Set for stroke. (Geyh et al., 2004) ICF has proved its usefulness in describing, comparing and contrasting information from outcome measures used to collect quantitative data, qualitative research results and clinical patient reports across diagnoses, settings, languages and countries. (Fayed et al., 2011) It has been used as a concept of teamwork in order to improve multidisciplinary and interdisciplinary communication. That provides a systematic approach to assessment, goal setting and rehabilitation planning in the framework of ICF. It also helps to clarify multidisciplinary team roles and demonstrate clinical reasoning in stroke rehabilitation. (Rentsch et al., 2003) However, ICF do not satisfy the criteria of objective measurement. (Bostan et al., 2012)

\subsubsection{Disability Assessment}

Persons after stroke can experience different combinations of problems in all levels of functioning. (Ali et al., 2013b) The reasons for assessment of the problems can be several, such as, clinical decision making, monitoring quality of care, research or policy making. (Kucukdeveci et al., 2011) Moreover, for effective planning of interventions and activation of health services, the procedure of data collection in health contexts has to be precise and quick. (Quintas et al., 2012) Rehabilitation specialists from multiple professions and disciplines can be involved in the process. (Ali et al., 2013b) The bio-psycho-social nature of disability and holistic approach of rehabilitation complicates comprehensive assessment and synthesis of evidence. (Quinn et al., 2009b) Approaches to assess disability and data collection method vary across countries and influence the results. (World Report on Disability, 2011).

There is an extensive selection of assessment tools that differs in scope and psychometric properties. (Ali et al., 2013b; Haigh et al. 2001; StrokeEngine, 2013) These instruments vary in content of the ideas and the aspect measured, such as restrictions or satisfaction (Stallinga et al., 2014), or capacity and performance (Tarvonen-Schroder et al., 2015), that influences results.

One way of how to classify outcome assessment instruments is according to levels of ICF. (Ali et al., 2013b; Salter et al., 2005a; Salter et al,. 2005b; Salter et al,. 2005c) For 
evaluation of 'body functions' instruments, such as Mini-mental State Examination (Folstein et al., 1975) and modified Ashworth Scale (Bohannon and Smith, 1987) are used. The Barthel Index (Mahoney and Barthel, 1965) evaluates the aspects of 'Activities and Participation' component. The ICF Brief Core Set has been suggested as suitable tool for the collection of fundamental information and identification of main areas of interventions. (Quintas et al., 2012) It has been recommended as a starting point in the assessment of stroke patients. (Lemberg et al., 2010; Quintas et al., 2012) The ICF Brief Core Set has also been suggested to link instruments to the ICF as a reference framework. (Cieza et al., 2005; Fayed et al., 2011) However, ICF does not contain concept of quality of life. (Colombetti et al., 2012) Therefore, quality of life could be classified as separated concept of outcomes. (Kucukdeveci et al., 2011)

There are several instruments, such as the National Institutes of Health Stroke Scale (Brott et al., 1989), Glasgow Coma Scale (Teasdale and Jennett, 1974) and modified Rankin Scale (mRS) (Lees et al., 2012) that have been proved as useful in reporting acute stroke outcomes. The mRS (van Swieten et al., 1988) is one of the most commonly used functional outcome tools in stroke research. (Quinn et al., 2009a) It is also included in the WHO's international stroke surveillance system. (Mackay et al., 2006) The instrument is easy and quick to use and has been proven valid and clinically relevant for overall assessment of stroke treatment. (Banks and Marotta, 2007) However, the content of the mRS does not seem to be related to the concept of ICF (Berzina et al. 2015) and it is not in line with the comprehensive approach of rehabilitation. Therefore, it is useful for overall description of stroke outcome, such as acute stroke research (Lees et al., 2012), but not valid for clinical decision making in rehabilitation.

Instruments that are used in reporting outcomes can be observation based that are done by clinicians, such as FIM (Cournan, 2011) or self-reported, such as Medical Outcomes Study Short Form 36 or SF-36 (Ware and Sherbourne, 1992); generic or disease-specific (Kucukdeveci et al., 2011) - WHODAS 2.0 ( Measuring Health and Disability, 2010) and Stroke Impact Scale (Duncan et al., 2001), respectively. The WHODAS 2.0 is directly linked to ICF components of 'Activities and Participation,' thereby evaluating person's ability to work and carry out the daily routine activities necessary to fulfil his or her roles at home, work, school or in other social areas rather than focusing on clinical aetiology of the disability. (Measuring Health and Disability, 2010) This instrument, however, would not be relevant in clinical setting, when person has not yet returned to his/her daily routine.

Most commonly used instruments for assessment of stroke consequences basically covers all spectrum of outcome concepts based on ICF levels of functioning and quite 
frequently overlaps in terms of outcome concept. (Ali et al., 2013b; Schepers et al., 2007). Choosing the most appropriate for collation and interpretation of results is difficult for researchers and clinicians and the choice depends on the objective of particular instrument and its application. (Ali et al., 2013a; Ali et al., 2013b; Carter et al., 2011; Frontera and DeLisa, 2010)

\subsection{Chain of care for persons after stroke}

WHO define rehabilitation as "a set of measures that assist individuals who experience, or are likely to experience, disability to achieve and maintain optimal functioning in interaction with their environments". (World Report on Disability, 2011) It is "a process of active change by which person who has become disabled acquires the knowledge and skills needed for optimal physical, psychological and social functioning". (PRM, Section of UEMS, 2006) Rehabilitation reduces disability and is aiming to improve person's independency, as much as possible, through minimizing negative effects of stroke and/or enabling adaptation strategies. Thus, rehabilitation encompasses a heterogeneous group of interventions, applied by different health care and health related professionals, using disparate methodologies in any stage after stroke. (Quinn et al., 2009b) It should be started as soon as possible after the event, such as stroke and continue as long as necessary even after discharge from hospital, but with a different content and intensity. (Ward et al., 2012) The long-term continuous rehabilitation along with improved health outcomes, can reduce costs by shortening hospital stays, as well as reduce disability and improve quality of life. (Takac et al., 2014)

On 2014, the World Stroke Organisation published the Global Stroke Services Guidelines and Action Plan. (Lindsay et al., 2014) According to this plan, direct role of rehabilitation in form of stroke units, starts immediately after the diagnostic and hyperacute treatments, such as trombolysis or neurosurgery ( European Stroke Organization ,2008; Steiner et al., 2006) and continues until the reintegration into community. Thus, it covers all continuum of care (Gutenbrunner et al., 2010; Ward et al., 2012).

The stroke unit is an organized inpatient care that is provided by multidisciplinary (including rehabilitation professionals) team and leads to better outcomes in terms of both, survival and independence. (Ayis et al., 2013; Langhorne et al., 2012) It is recommended that within the stroke unit all patients have an assessment for further rehabilitation needs and a individualized rehabilitation plan is developed. (Lindsay et al., 2014) Different rehabilitation techniques are applied depending on the individual needs. Interaction of person's different needs determines the overall success. (PRM, Section of UEMS, 2006; Quinn et al. 2009b) 
Both, acute and post-acute rehabilitation mainly focus on impairment reduction and improvement of independence in activities of daily living. (Quinn et al., 2009b; Ward et al., 2012) Later, when the person returns to his/her usual environment the focuses should change from medical to social aspects. (Mayo et al., 2015; Takac et al., 2014) However, medical problems can be of importance in any aspect of person's life, and therefore should not be excluded from the scope of care. (Hanga et al., 2016; Lindsay et al., 2014; Takac et al., 2014; Walsh et al., 2014)

The phase of post-acute rehabilitation serves as transition from the early rehabilitation in acute setting to community based follow-up rehabilitation. In- and outpatient rehabilitation services should be goal-oriented and multi-professional. (Ward et al., 2012) However, there is no unified selection of patients for in-patient rehabilitation in the post-acute setting. (Hakkennes et al., 2011) The existing inclusion criteria has a permissive nature and the availability and effectiveness of services in different countries varies depending on local policy and available resources. (De Wit et al., 2007; Putman and De Wit, 2009; Ward et al., 2010) Therefore, stroke care, as well as outcomes differs between countries. (Ayis et al., 2013; De Wit et al., 2007; S. Meyer et al., 2015; Weir et al., 2001, Rhoda et al., 2014) There is also lack of definite criteria that would predict effectiveness of post-acute rehabilitation service. However, comparison between countries could serve as guidance on how to optimize stroke care. Therefore, evaluation of rehabilitation as a complex intervention is in the interests of clinicians, researchers and policy makers. (P. Craig et al., 2008; De Wit et al., 2007) 


\section{METHODS}

The research is conducted in conformity with the ethical principles of Declaration of Helsinki. Part 1 and 2 of the study are approved by the Ethics Committee of Rịga Stradinšs University, Latvia (27.09.2012.); Part 3 is approved by the Regional Ethical Review Board in Gothenburg, Sweden (No T129-05/Ad 419-04 and 390-05).

\subsection{Study designs}

This PhD project is organized in four parts and following designs were used (Carter et al., 2011):

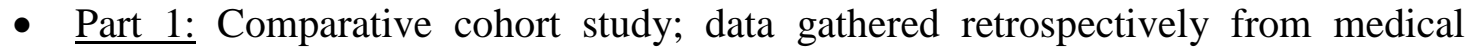
charts and from stroke data registry;

- Part 2: Cross-sectional study

- $\quad$ Part 3: Cross-sectional study

- $\quad$ Part 4: Comparison based on the results of part 2 and 3.

\subsection{Study population}

The overall study population composed of data from 1055 persons living in Latvia and 1991 persons from Sweden. The populations for each part of the project are demonstrated on a Figure 4.1.

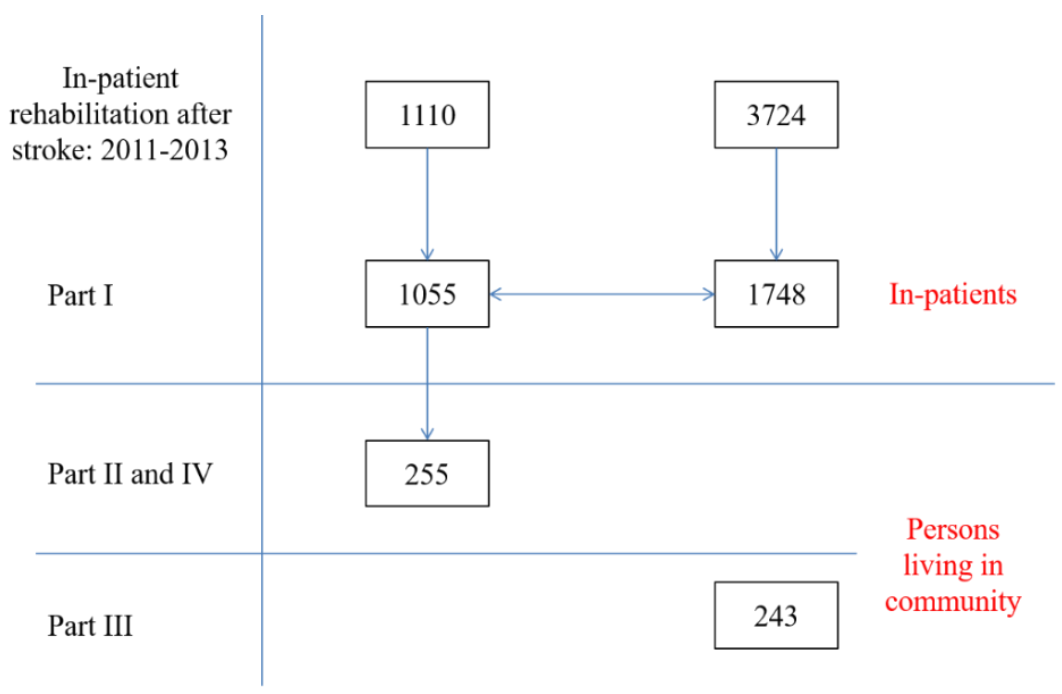

Figure 4.1 The number of patients included in the project 
Baseline characteristics of all study populations are presented in Table 4.1.

Table 4.1

\section{Baseline characteristic of study populations}

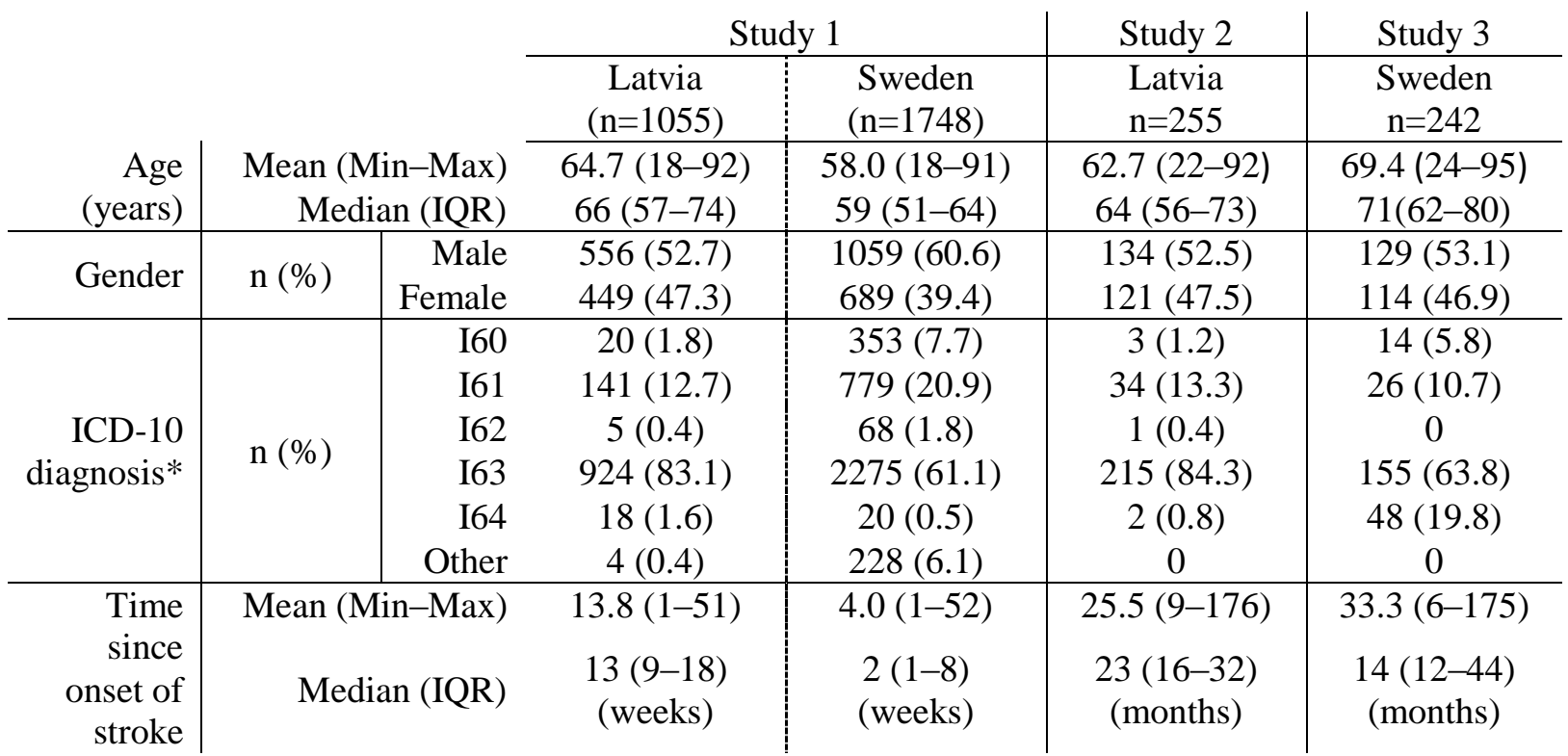

*ICD-10 Diagnosis: I60 - Subarachnoid haemorrhage, I61 - Intracerebral haemorrhage; I63 -

Cerebral infarction; I64 - Stroke, not specifies as haemorrhage or infarction

\subsection{Inclusion criteria}

Main inclusion criteria for Part 1-4:

- Diagnosis of stroke (ICD-10 codes I60-I67 (2010b)), clinically determined by a physician specialists at acute stage of stroke according to World Health Organization (WHO) criteria (WHO Task Force on Stroke and Other Cerebrovascular Disorders, 1989) and confirmed by computed tomography (CT)

- $\quad$ Age at least 18 .

For the separate parts, following additional inclusion and exclusion criteria were applied:

\section{Part 1:}

All persons who received specialised in-patient rehabilitation after stroke in Latvia or Sweden between January 1, 2011 and December 31, 2013 were included in this study, except those to whom following exclusion criteria were attributable. 
- Started rehabilitation less than 1 week or more than 1 year post stroke

- Lack of information regarding time between stroke onset and start of specialised in-patient rehabilitation

- Patient discharged from rehabilitation centre due to death or acute health problem that required re-hospitalization in acute setting.

Part 2 and 4: Inclusion criteria:

Persons who had earlier received specialized in-patient rehabilitation in the post-acute phase of stroke at Department of Neurorehabilitation in National Rehabilitation Centre (NRC) "Vaivari", Latvia from January 1, 2011 to December 31, 2013, but were at the time, at least 9 months post stroke, living in their own home community were included in the Part 2 and Part 4 of this study.

\section{Part 3:}

A convenience sample of persons after stroke were recruited among former patients from stroke units or a rehabilitation clinic, or among those in a contact with a physical therapist in the community or through patient organizations. The data in this study was gathered between May of 2003 and June of 2007. Data was gathered for two different scopes; a trial with the aim to validate the ICF Core Sets (part of an international project) as well as a project where the ICF data was gathered longitudinally. For this cohort following additional inclusion criteria were applied:

- Having given written informed consent (or consent given by next to kin)

- Persons living in community

- Time from onset of stroke - at least 6 month.

\subsection{Data collection procedure}

\section{Population in Latvia:}

- Parts 1 and 2: All patients who received rehabilitation after stroke in the Department of Neurorehabilitation in National Rehabilitation Centre "Vaivari" during the period of time between January 1, 2011 and December 31, 2013, were identified through the computerized hospital register. Pre-specified data were gathered from the charts (GB) and entered into a computer file. This is the only rehabilitation centre in Latvia that provides public funded in-patient rehabilitation in the post-acute phase of stroke. 
- Parts 2 and 4: Based on information gathered from medical charts, the persons were asked to participate in the study by telephone. After informed consent, a set of questions that included current socio-demographic information, as well as WHO Disability Assessment Schedule 2.0 (WHODAS 2.0) (2010a) were sent by mail or e-mail. The questionnaires sent by mail also contained return envelope. The e-mail to respondents contained an on-line link to the questionnaire, which if fulfilled, automatically sent the reply to the researcher. There were no reminders sent to the respondents. During the phone conversation, the preferred responding language (Latvian or Russian) was asked for. This was done because $37 \%$ of population in Latvia use Russian as their primary language (2011. gada tautas skaitīšanas rezultāti īsumā, 2011). If the person could not fill out the questionnaire himself or herself, their next of kin could perform it.

\section{Population in Sweden:}

- Part 1: The data were obtained from the Swedish rehabilitation quality register "WebRehab Sweden" (Sunnerhagen et al., 2014) for the same period of time (January 1, 2011 - December 31, 2013). This registry has a >95\% coverage of in-patients rehabilitation units in Sweden. (Sunnerhagen et al., 2014)

- Part 3: Participants were seen either at home or at hospital and interviewed by using semi-structured questions based on the extended version of Comprehensive ICF Core Set for Stroke (Ewert et al., 2005). After the interview was completed, the core set was filled in using all the received information and impressions of interviewed patient.

\subsection{Instruments and outcome variables}

1. Socio-demographic, medical data and information of organisation of rehabilitation were used in all four studies. Detailed information on these outcomes is reported in Table 4.2. 
Socio-demographic, medical and organisational characteristics used in different parts of the study

\begin{tabular}{|c|c|c|c|c|}
\hline Variable & Description of variable & Part 1 & Part 2 & $\begin{array}{l}\text { Part } 3 \text { and } \\
\text { Part } 4\end{array}$ \\
\hline Population & Latvian vs. Swedish & $\checkmark$ & - & - \\
\hline Age & (years) & $\checkmark$ & $\checkmark$ & $\checkmark$ \\
\hline Gender & Male vs. female & $\checkmark$ & $\checkmark$ & $\checkmark$ \\
\hline Type of stroke diagnosis & $\begin{array}{l}\text { I60; I61; I62; I63; I64; } \\
\text { Other }\end{array}$ & $\checkmark$ & $\checkmark$ & - \\
\hline Side of lesion in brain & $\begin{array}{l}\text { Right hemisphere; Left } \\
\text { hemisphere; } \\
\text { Vertebrobasilar system; } \\
\text { Different Locations; } \\
\text { Other/unknown }\end{array}$ & $\checkmark$ & $\checkmark$ & - \\
\hline $\begin{array}{l}\text { Time since onset of stroke } \\
\text { until rehabilitation }\end{array}$ & (weeks) & $\checkmark$ & $\checkmark$ & - \\
\hline $\begin{array}{l}\text { Time since onset of until } \\
\text { the fulfilment of } \\
\text { questionnaire/interview }\end{array}$ & (months) & - & - & $\checkmark$ \\
\hline Length of rehabilitation & (days) & $\checkmark$ & $\checkmark$ & - \\
\hline Work status after stroke & Working vs. not working * & - & $\checkmark$ & - \\
\hline $\begin{array}{l}\text { Time after discharge from } \\
\text { rehabilitation }\end{array}$ & (months) & - & $\checkmark$ & - \\
\hline Preferred language & Latvian vs. Russian & - & $\checkmark$ & - \\
\hline Education & $\begin{array}{l}\text { Primary; Secondary; } \\
\text { Higher; Studies ongoing; } \\
\text { Other }\end{array}$ & - & $\checkmark$ & - \\
\hline Place of living & Countryside vs. City & - & $\checkmark$ & $\checkmark$ \\
\hline Living situation & Alone vs. In family & - & $\checkmark$ & - \\
\hline
\end{tabular}

The following assessment tools is ordered according to the time of their development, starting with the most earlier published tool.

2. The Functional Independence Measure (FIM) was used to define the levels of independence at discharge from rehabilitation (Cournan, 2011).
a. $\quad$ Used in Parts 1 and 2
b. Description of the instrument:

- Background: The Functional Independence Measure is used as assessment tool for functioning in rehabilitation since 1987. (Cournan, 2011) FIM is also used as an routine clinical assessment tool in NRC "Vaivari" and as outcome assessment for "WebRehab Sweden" database. It is used for evaluation at the beginning of rehabilitation and at the discharge from rehabilitation unit by rehabilitation professionals after observation of the patients' performance on the ward. 
- Structure: The instrument consists of 18 items that forms six domains and two scales - Motor and Cognitive. (See Table 4.3)

Table 4.3

\begin{tabular}{c|c|c}
\multicolumn{2}{c}{} & \multicolumn{2}{c}{ Description of the FIM domains } \\
\cline { 2 - 3 } Motor Scale & Self-care & 6 items \\
\cline { 2 - 3 } & Sphincter & 2 items \\
\cline { 2 - 3 } & Transfer & 3 items \\
\cline { 2 - 3 } & Locomotion & 2 items \\
\hline Cognitive & Communication & 2 items \\
\cline { 2 - 3 } Scale & Social Cognition & 3 items
\end{tabular}

- Scoring: Eeach item is scored on a 7-point scale (1-7). Grade 7 and grade 6 are used to describe complete and modified independence, respectively. Grades 5 to 1 are used to describe different levels of dependence, which are supervision, minimal assistance, moderate assistance, maximal assistance and total assistance, respectively (VistA System, 2003).

c. Outcome variables: the FIM data at the beginning of rehabilitation and a discharge were grouped under 6 domains:(Grimby et al., 1996)

- 'Self-care'

- 'Sphincter'

- 'Transfer'

- 'Locomotion'

- 'Communication'

- 'Social Cognition'.

To meet the criteria of acceptable psychometric properties, the FIM response scores need to be collapsed. (Lundgren Nilsson and Tennant, 2011) Three response categories in all items has been showed as an optimal approach for addressing the issue. (Dallmeijer et al., 2005, Nilsson et al., 2005) The overall results for each domain were presented in a trichotomized way based on the extent of the person's need for help to fulfil the activity in the following manner: 'Total dependence' (1) was defined by any score being 1 or 2; 'Partial dependence' (2) if any score was 3, 4 or 5, without 1 or 2; 'Independent' (3), if all items got a score of 6 or 7 .

3. The ICF Core Set for Stroke for evaluation of functional outcome.
a. Used in Part 3.
b. Description of the instrument: 
- Background: The ICF was launched in 2001. It was based on the International Classification of Impairment, Disabilities and Handicaps (ICIDH) from 1980 (International Classification of Functioning, Disability and Health, 2001). In 2004, the first version of the ICF Core Set for stroke patients was published (Geyh et al., 2004) which included 130 second-level categories of the ICF. In 2005, the stroke core set was extended to a version that included 166 categories involving secondlevel classification. (Ewert et al., 2005; Grill et al., 2005)

- $\quad$ Structure: This extended version of ICF Core Set for Stroke consists of 59 categories of body functions, 11 categories of body structures, 59 activities and participation categories and 37 environmental factors) (Glassel et al., 2012, Glassel et al., 2014).

- "Scoring": To describe the severity of the problem, 4 qualifiers are used for each code ( 0 is used for "no problem" and 4 for "complete problem", the qualifiers 8 and 9 are also used if the problem is not specified or not applicable). Environmental factors can have positive or negative influence on the person's functioning. For qualifiers are used the same $(0-4)$ scale, but to denote facilitator the point (that is used in case of barriers) is replaced with plus sign. (International Classification of Functioning, Disability and Health, 2001).

c. Outcome variables: The qualifier scale of the ICF categories were dichotomized: For body functions and structures and activities and participation the qualifier 0 (no problem) was maintained, the qualifiers 1 to 4 were recoded to 1 (problem), the response option 8 (not specified) was treated as missing and the response option 8 (not applicable) was recoded to 0 (no problem); For facilitators of environmental factors the qualifiers 1 to 4 (facilitators) were recoded as 1, 0 (neither/nor) were maintained, the response option 8 (not specified) were treated as missing, response option 9 (not applicable) and 1 to -4 (barriers) was recoded as 0 (neither/nor); For barriers of environmental factors the qualifiers -1 to -4 (facilitators) were recoded as 1,0 (neither/nor) were maintained, the response option 8 (not specified) were treated as missing, response option 9 (not applicable) and 1 to 4 (facilitators) was recoded as 0 (neither/nor); The problems were counted under different levels of functioning and facilitators and barriers were counted according to main groups of environmental factors.

4. The World Health Organization Disability Assessment Schedule 2.0 (WHODAS 2.0) used for evaluation of self-reported disability level.
a. $\quad$ Used in Parts 2 and 3
b. Description of the instrument: 
- Background: WHODAS 2.0 is developed by the WHO based on extensive review and field testing to measure the level of disability regardless the cultural or medical background. It is directly linked to the 'Activity and Participation' component of ICF (Ustun et al., 2010; Measuring Health and Disability, 2010).

- $\quad$ Structure: WHODAS 2.0 consists of 36 items and captures the level of functioning in six domains of life: cognition, mobility, self-care, getting along, life activities and participation (See Table 4.4)

Table 4.4

\section{Description of the WHODAS 2.0 domains}

\begin{tabular}{r|l|l} 
Domain 1 & 'Cognition' (understanding and communicating) & 6 items \\
\hline Domain 2 & 'Mobility'(moving and getting around) & 5 items \\
\hline Domain 3 & $\begin{array}{l}\text { 'Self-care' (attending to one's hygiene, dressing, eating } \\
\text { and staying alone) }\end{array}$ & 4 items \\
\hline Domain 4 & 'Getting along' (interacting with other people) & 5 items \\
\hline \multirow{2}{*}{ Domain 5 } & Part 1: 'Household activities' (domestic responsibilities) & 4 items \\
\cline { 2 - 3 } & Part 2: 'Work or school activities' & 4 items \\
\hline Domain 6 & $\begin{array}{l}\text { 'Participation' (joining in community activities, } \\
\text { participating in society) }\end{array}$ & 8 items
\end{tabular}

- $\quad$ Scoring: For each of items, uniform 1 to 5 response scale is used, where " 1 " is "none" difficulties and " 5 " - "extreme or cannot do". (Measuring Health and Disability, 2010).

c. Outcome variables: For the WHODAS 2.0 data set, the simple approach to missing data and the complex scoring method were used. The scores of each item were recoded according to the suggested algorithm. (Measuring Health and Disability, 2010) The simple approach to the missing data means that if responses in one or two items were missing, the mean raw score of the corresponding domain replaced the missing response. In the case that more than two responses were missing in the data set, the response remained missing and the mean score was not used. Complex scoring is based on the "item-response-theory" and the each item's level of difficulty is taken into account and weighted accordingly. (Measuring Health and Disability, 2010)

Recoded scores were summed and converted into a metric ranging from 0 (no disability) to 100 (full disability) (Measuring Health and Disability, 2010) for each of domains described above and the total WHODAS 2.0 score. 


\subsection{Statistical methods}

All statistical analyses were performed using SPSS (Version 21.0). Statistical methods used for each part of the study are showed in Table 4.5.

Table 4.5

Statistical methods used for the study

\begin{tabular}{c|c|c|c} 
& Part 1 & Part 2 & Part 3 \\
\hline Descriptive statistics & $\checkmark$ & $\checkmark$ & $\checkmark$ \\
\hline $\begin{array}{c}\text { Sinear regression } \\
\text { Standard multiple regression }\end{array}$ & & $\checkmark$ & \\
\hline Ordinal logistic regression & $\checkmark$ & & $\checkmark$ \\
\hline Binary logistic regression & & & $\checkmark$ \\
\hline Statistical analysis to compare groups & $\checkmark$ & &
\end{tabular}

To describe suggested causality of variables the conceptual model, based on principles of direct acyclic graphs, were used for Part 1 and Part 2. (Shrier and Platt, 2008; Textor et al., 2011) In current situation, it was used to describe interaction of covariates used in the statistical analysis to minimize the magnitude of possible bias or inappropriate causal interferences due to the observational study design.

\subsubsection{Data analysis for Part 1}

1. To compare the Latvian and the Swedish stroke care, a qualitative description of both stroke care systems was completed.

2. Independent samples t-test and $\chi^{2}$ test of independence was used to compare the characteristics between two populations.

3. Shifts in proportions of these 3 levels of functioning were analysed for Latvia and Sweden at admittance and discharge and reported using bar graphs. The Wilcoxon signed rank test was conducted to assess the change of the proportions between admittance to and discharge from rehabilitation and effect sizes were reported.

4. As an outcome for analysis, trichotomized FIM discharge scores for 6 domains were used. For each of outcome, the common odds ratio and 95\% confidence intervals were reported for the shift in the direction of a better outcome towards either population. The odds ratio was estimated using ordinal logistic regression analysis. For each outcome three analyses were conducted:

- unadjusted analysis (without covariates) 
- $\quad$ adjusted for admittance scores (the score shift of the trichotomized scale for the corresponding domain evaluated at the admittance to rehabilitation)

- a "fully" adjusted analysis. Controlling factors for the last model were chosen based on the unique contribution for each factor when conducting an analysis with age, gender, type of diagnosis, side of lesion in the brain, time since onset, length of rehabilitation and proportions of levels of dependence at admittance for the corresponding domain as covariates.

The results with a significance level $<0.01$ were reported.

The conceptual model for the analyses in Part 1 is shown in Figure 4.2.

\subsubsection{Data analysis for Part 2}

General linear models for stepwise regression analysis (Bursac et al., 2008) was used to predict the summary scores for each of the seven domains and the total score of the WHODAS 2.0. The initial model for regression analysis is illustrated in Figure 4.3.

The steps for the multiple regression model building were as follows:

Step 1: Univariate regression analyses were done to evaluate the association between each of 16 predictor variables and the outcome.

$\underline{\text { Step 2: }}$ Multiple regression analysis with all predictor variables with a $\mathrm{p}$ value $<0.25$ at Step 1 were included in the model.

Step 3: Those variables, which showed p values $>0.25$ were excluded from the model and multiple regression analysis with variables, significant in step 2 was performed.

Step 4: The variables rejected at step 1 were reinserted one by one in the model with remaining variables from Step 3. If the variable turned out to be significant $(\mathrm{p}<0.05)$, it was kept in the model.

The best model was selected by comparing the models with an $\mathrm{F}$ test. If the two models were significantly different $(\mathrm{p}>0.05)$, the model with higher $\mathrm{R}^{2}$ values were chosen. If the models were not significantly different, the model with the least number of explanatory variables was chosen. 


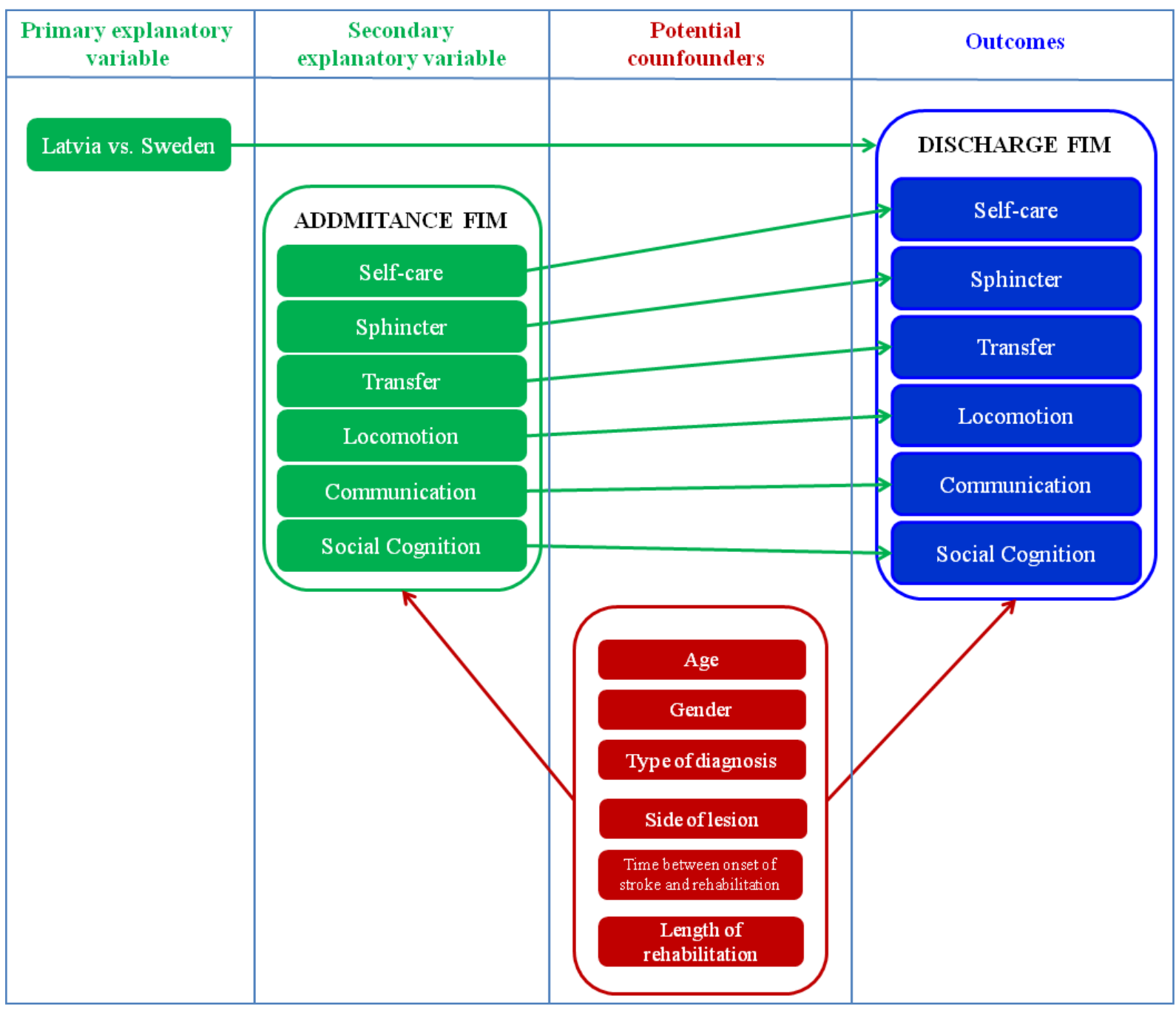

Figure 4.2 The conceptual model for ordinal regression analysis in Part 1 


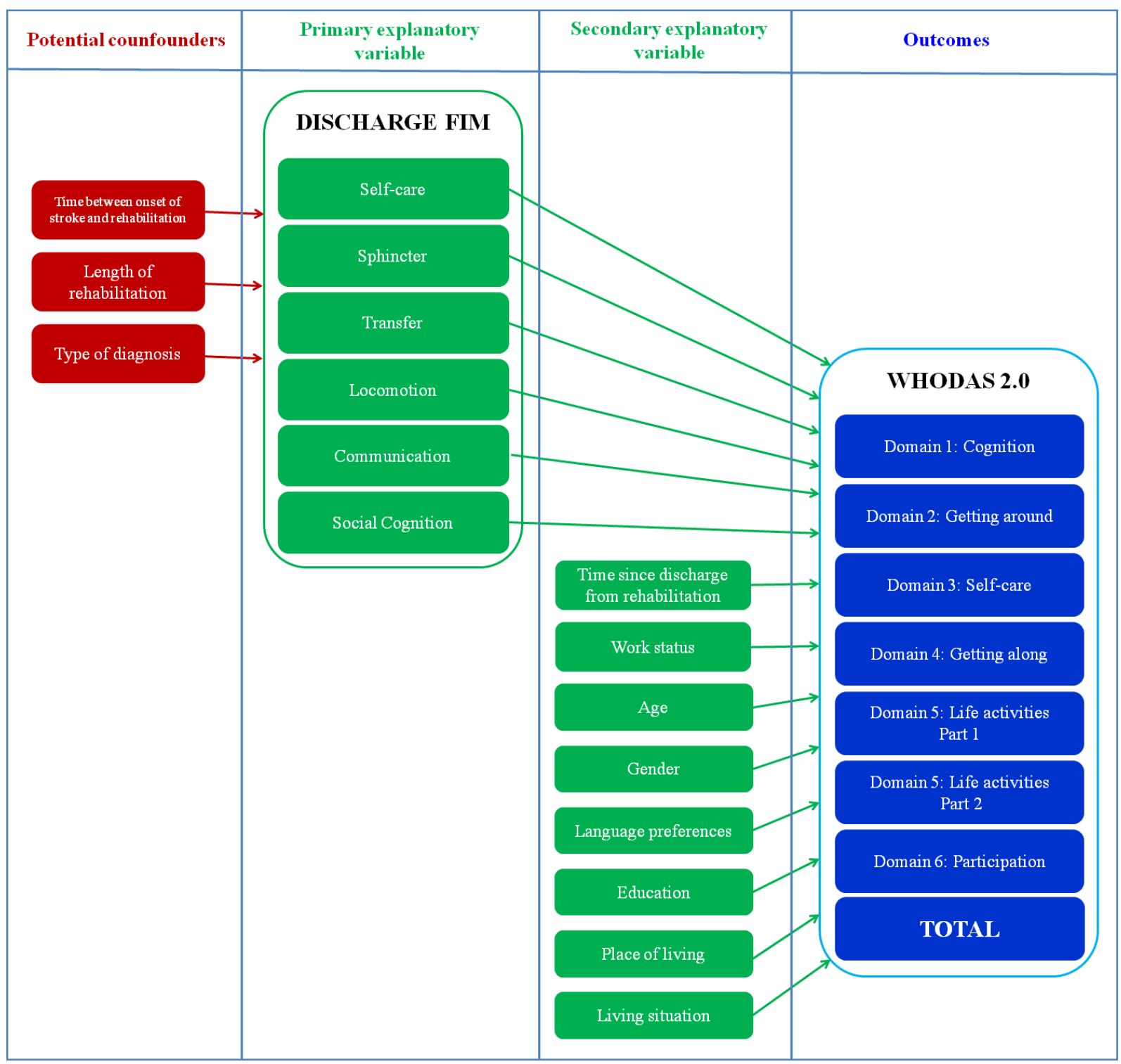

Figure 4.3 The conceptual model for the initial model of the analysis for Part 2

For each of the final models, analyses were conducted to ensure no violation of the assumptions of normality, linearity, multi-co-linearity and homoscedasticity.

Each of the significant factors in the final model in turn, were excluded from the model and changes of $\mathrm{R}^{2}$ were reported, to illustrate the factors' unique contributions to the model.

Work as an explanatory factor was excluded from the analysis of Domain 5.2 since this domain evaluates the ability to work and thus were not answered by those who were unemployed. 


\subsubsection{Data analysis for Part 3}

Standard multiple regression was used to predict:

1. the number of problems in functioning:
a. in the levels of 'Body Functions'
b. in the levels 'Activities and Participation'

2. the number of barriers and facilitators in environmental factors divided in the five main groups:
a. 'Products and technology'
b. 'Natural environment and human made changes to environment'
c. 'Support and relationships'
d. 'Attitudes'
e. 'Services, systems and policies'.

Direct logistic regression was performed to assess the impact of personal factors on the selected domains of 'Activities and Participation' and 'Environmental factors' in the context of ICF.

- 'Moving around in different locations' (d469)

- 'Toileting' (d530);

- 'Dressing' (d540);

- 'Doing housework' (d640);

- 'Recreation and leisure' (d920);

- 'Physical geography' (e210);

- 'Immediate family' (e310).

These domains were selected based on its properties for reflection the need of assistance and previously published as common occurring problems (Alguren et al., 2009; Quintas et al., 2012; Snogren and Sunnerhagen, 2009) as well as clinical judgment.

In both cases standard multiple regression analysis and direct logistic regression analysis same independent variables were used:

- $\quad$ Age;

- Gender;

- $\quad$ Place of living (countryside or city);

- $\quad$ Time since onset of stroke. 
The unique contribution of age, gender, place of living and time since rehabilitation on the WHODAS 2.0 domains were reported in terms of Beta values, 95\% confidence intervals and $p$ values. Results are based on the final models of linear regression analysis conducted for Part 2 of this study. 


\section{RESULTS}

\subsection{Results of Part 1}

\subsubsection{Organization of rehabilitation - qualitative comparison between populations}

A qualitative comparison between stroke care systems in Latvia and Sweden is shown in the Table 5.1.

Table 5.1

\section{Qualitative description of rehabilitation systems}

\begin{tabular}{|c|c|c|c|}
\hline & & Latvia & Sweden \\
\hline 1. & Stroke units & Since June 1, 2000 & Since 1990s \\
\hline 2. & $\%$ treated at the stroke unit & No exact data available & $91 \%$ \\
\hline 3. & Stroke rehabilitation available since & 1995 & $1970 \mathrm{~s}$ \\
\hline 4. & $\begin{array}{l}\text { Initial functional assessment to determine } \\
\text { rehabilitation needs and receive an } \\
\text { individualized rehabilitation plan }\end{array}$ & $100 \%$ in stroke units & $100 \%$ in stroke units \\
\hline 5. & $\begin{array}{l}\text { Post-acute rehabilitation: } \\
\text { All patients who are admitted to inpatient } \\
\text { rehabilitation following stroke are treated } \\
\text { in a specialized stroke rehabilitation unit }\end{array}$ & No & No \\
\hline 6. & Multi professional team & Yes & Yes \\
\hline 7. & Funding & Public & Public \\
\hline 8. & Patient borne costs & $\begin{array}{l}\text { Yes } \\
13.50 \text { Euro, except } \\
\text { persons with severe } \\
\text { disability, low-income } \\
\text { and other social groups }\end{array}$ & $\begin{array}{l}\text { Yes } \\
\text { Depend on the county, } \\
\text { but not more than } 10 \\
\text { Euro }\end{array}$ \\
\hline 9. & Follow-up & Some & Yes \\
\hline 10. & Other options for rehabilitation & $\begin{array}{l}\text { Home based } \\
\text { rehabilitation; } \\
\text { Day rehabilitation } \\
\text { units; } \\
\text { Out-patient } \\
\text { rehabilitation }\end{array}$ & $\begin{array}{l}\text { Home based } \\
\text { rehabilitation; } \\
\text { Day rehabilitation } \\
\text { units; } \\
\text { Out-patient } \\
\text { rehabilitation }\end{array}$ \\
\hline 11. & Quality registers & No & $\begin{array}{l}\text { "Riks-Stroke", the } \\
\text { Swedish stroke register } \\
\text { since 1994; } \\
\text { "WebRehab" since } \\
1997\end{array}$ \\
\hline
\end{tabular}




\subsubsection{Quantitative comparison of populations}

The description of age, gender and type of diagnosis is described in Table 4.1. The differences in timing of rehabilitation as well as the shift of proportions in 'totally dependent', 'partially dependent' and 'independent' groups between admittance to and discharge from rehabilitation for the Latvian and the Swedish stroke populations is illustrated in Table 5.2.

The results of independent samples t-test showed that there was significant difference $(p<0.0005)$ between Latvian and Swedish populations in age, time since onset of stroke and length of rehabilitation:

1. The Latvian population were older than the Swedish with mean difference of 6.69 years $(95 \% \mathrm{CI}=5.75-7.64)$ and the magnitude of this difference were moderate $\left(\eta^{2}\right.$ $=0.06) \cdot \mathrm{t}(2801)=13.76$

2. Mean time since onset until the beginning of rehabilitation in Latvia were 9.77 weeks (95\% $\mathrm{CI}=9.26-10.28)$ longer and the magnitude of this difference was large $\left(\eta^{2}=0.32\right) . t(1970)=36.12$

3. Mean time length of rehabilitation was by 43.21 days $(95 \% \mathrm{CI}=40.96-45.55)$ longer in the Swedish population and the magnitude of this difference was large $\left(\eta^{2}=0.44\right) \mathrm{t}(1945)=46.74$

The $\chi^{2}$ test for independence showed that populations were also statistically significant in distribution of gender, diagnosis and side of lesion $(\mathrm{p}<0.0005)$.

- For gender $\chi^{2}(1, \mathrm{n}=2803)=16.42 ; \varphi=-0.077$ indicating a small size of difference

- For type of diagnosis $\chi^{2}(5, \mathrm{n}=2799)=315.56$; Cramer's V=0.336 indicating a large difference

- For side of lesion $-\chi^{2}(4, \mathrm{n}=2379)=155.53$; Cramer's $\mathrm{V}=0.256$, that also indicates large differences.

The change towards higher level of independence between admittance and discharge from rehabilitation was statistically significant in each of domains for both populations. The detailed results of Wilcoxon Sing Test are reported in Table 5.3. 


\section{Quantitative comparison of two populations}

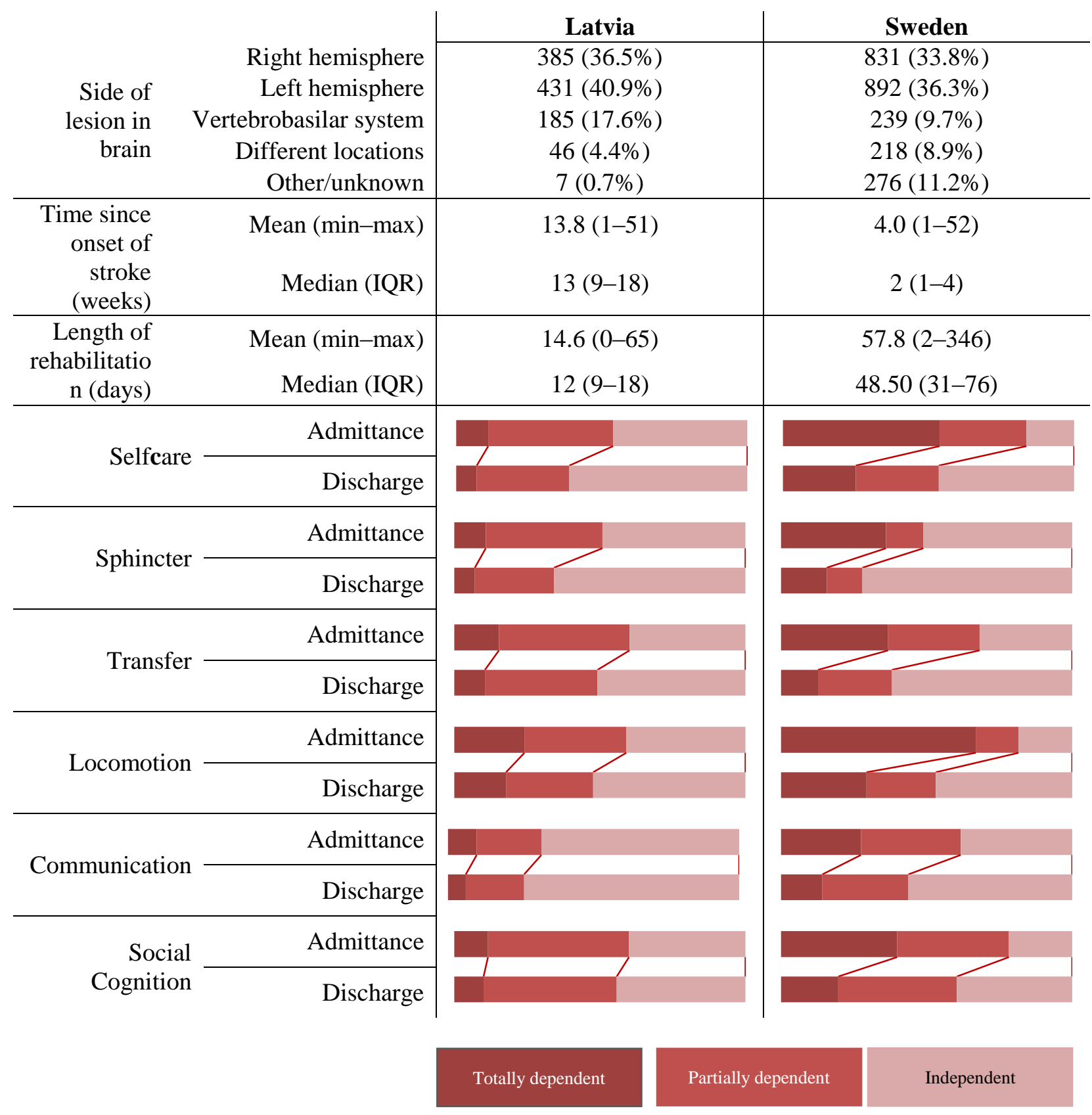

IQR - interquartile range 
Results of Wilcoxon signed rank test *

\begin{tabular}{cr|l|r|l} 
& \multicolumn{2}{c|}{ Latvia } & \multicolumn{2}{c}{ Sweden } \\
& $\mathrm{z}$ & $\mathrm{r}$ & $\mathrm{z}$ & $\mathrm{r}$ \\
Self-care & -13.68 & 0.30 & -23.84 & 0.43 \\
Sphincter & -14.15 & 0.31 & -18.46 & 0.33 \\
Transfer & -12.46 & 0.27 & -24.63 & 0.44 \\
Locomotion & -13.20 & 0.29 & -24.76 & 0.44 \\
Communication & -9.14 & 0.21 & -19.27 & 0.34 \\
Social Cognition & -7.35 & 0.17 & -21.10 & 0.38
\end{tabular}

$* \mathrm{p}$ values for all tests were $<0.0005$

\subsubsection{Ordinal regression analysis}

The odds ratio's between both populations for all 6 domains is reported in Figure 5.1. Results show that the odds for achieving a better level of independence at discharge from rehabilitation in 'self-care', 'locomotion', communication' and 'social cognition' were higher for Latvian patients, before the adjustment for significant factors. After adjustment for admittance scores for the corresponding domain (evaluated at the admittance to rehabilitation), the odds considerably changed in favour of the Swedish population. The odds of a better outcome for the Swedish population remained the same or somewhat decreased after full adjustment.

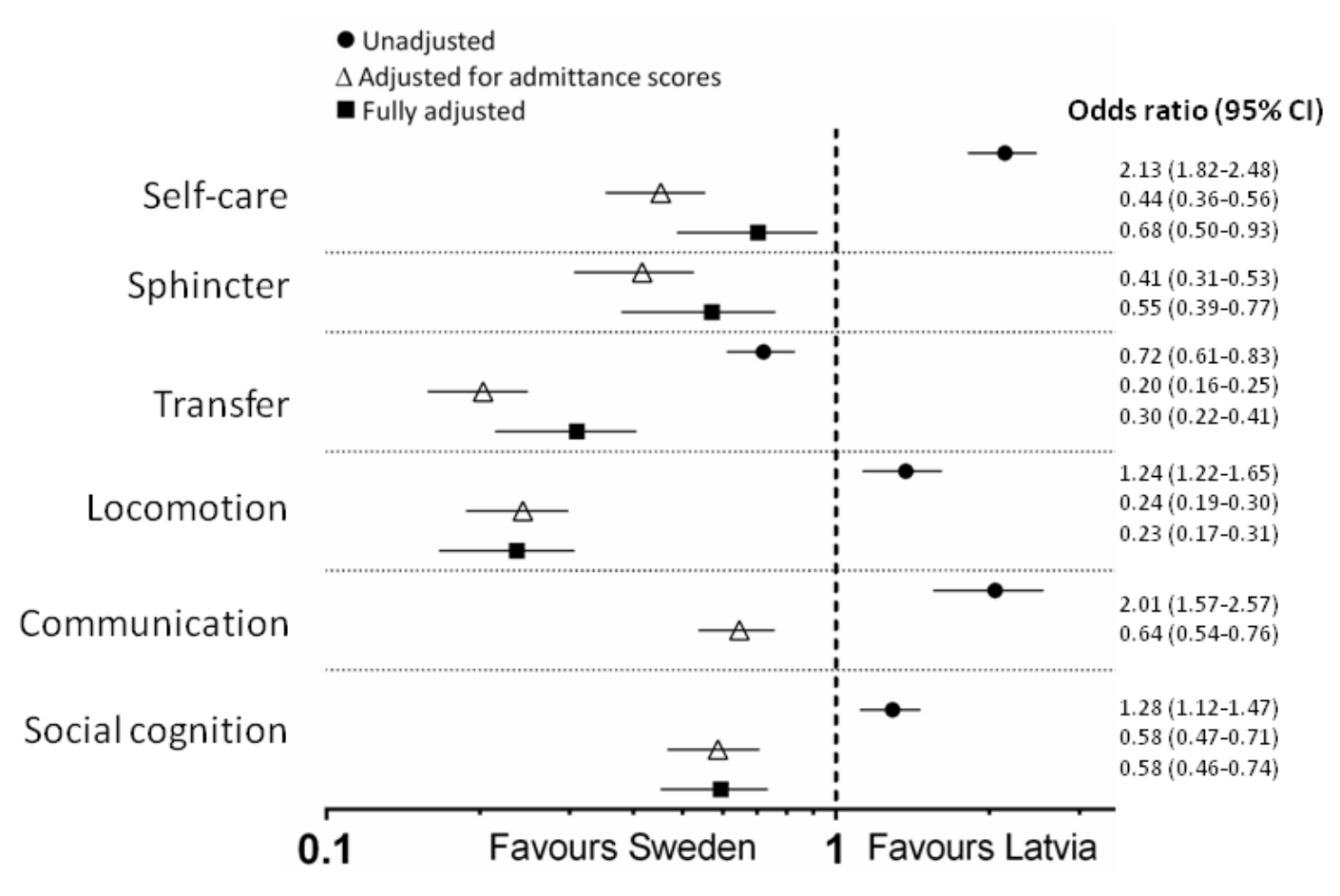

Figure 5.1 Forest plot for odds in favour of being more independent between Latvia and Sweden 
The dependence level for the corresponding domain at admittance, age, time since onset and length of rehabilitation were the significant contributing factors in almost all domains. In the domain 'Communication' a contribution of length of stay, while controlling for other factors, was not significant, therefore, it was excluded from the analysis. All estimated odds for a better outcome between populations in the analysis were statistically significant, except the unadjusted odds ratio for 'sphincter' ( $p=0.13$ ) and the "fully" adjusted odds ratio for 'communication' ( $p=0.67)$.

\subsection{Results of Part 2}

The final models of stepwise multiple regression analysis explained $23-43.5 \%$ of the variance in the outcomes. Overall results are reported in Table 5.4. by each domain and total score of WHODAS 2.0. Detailed descriptive statistics are reported in (Appendix 2).

The dependence level of 'Self-care' at discharge from rehabilitation was included and significant in the final explanatory model in five out of the seven analysed domains, as well as in the total WHODAS 2.0 score. Results indicated that being dependent at discharge led to a higher level of perceived disability. 'Locomotion' was significantly related to the 'Mobility, 'Self-care', 'Life activities: Work or school' and 'Participation' domains. Similarly, persons recognized by rehabilitation professionals as independent in 'Communication' at discharge, perceived fewer problems in the domains of 'Cognition', 'Getting along' and the total WHODAS 2.0 scores.

\subsection{Results of Part 3}

Detailed descriptive statistics are reported in (Appendix 3). Higher age indicated a greater number of problems in functioning, and age also had an influence on most of the areas in the environmental factors. Reports of restrictions in 'activities and participation' were more typical in older patients. Time since onset was found to be a factor that influences only the perception of attitudes. Living in a rural setting was associated with perceiving facilitators in 'natural environment and human made changes in the environment'. On the other hand, those who lived in the city reported facilitators in 'support and relationships' and 'attitudes'. The results of the complete analyses of the regression analyses are shown in Tables 5.5. and 5.6., where only independent variables with a p-value of less than 0.1 are included. 
Table 5.4

Results of final models of stepwise multiple regression analysis

\begin{tabular}{|c|c|c|c|c|}
\hline & & & $\mathrm{p}$ & $\begin{array}{l}\% \text { of unique } \\
\text { contribution }\end{array}$ \\
\hline \multicolumn{2}{|l|}{ Domain 1: 'Cognition' } & FIM Self-care & 0.109 & $1.3 \%$ \\
\hline $\mathrm{R}^{2}$ & $23.0 \%$ & FIM Communication & 0.005 & $4.7 \%$ \\
\hline $\mathrm{F}$ & $5.0(12,146)$ & FIM Social Cognition & 0.063 & \\
\hline $\mathrm{p}$ & $<0.0005$ & Work & 0.003 & $4.3 \%$ \\
\hline & & diagnosis & 0.093 & \\
\hline & & Gender & 0.051 & $1.5 \%$ \\
\hline \multicolumn{2}{|c|}{ Domain 2: 'Getting around' } & FIM Selfcare & 0.068 & $1.3 \%$ \\
\hline $\mathrm{R}^{2}$ & $43.5 \%$ & FIM Locomotion & $<0.0005$ & $5.7 \%$ \\
\hline $\mathrm{F}$ & $16.7(8,146)$ & Work & $<0.0005$ & $5.7 \%$ \\
\hline $\mathrm{p}$ & $<0.0005$ & Age & 0.011 & $2.1 \%$ \\
\hline & & Living situation & 0.059 & $1.0 \%$ \\
\hline & & Time since onset & 0.146 & \\
\hline \multicolumn{2}{|l|}{ Domain 3: 'Self-care' } & FIM Self-care & 0.123 & \\
\hline $\mathrm{R}^{2}$ & $40.0 \%$ & FIM Locomotion & 0.009 & $2.9 \%$ \\
\hline $\mathrm{F}$ & $18.9(6,162)$ & Work & $<0.0005$ & 9.8 \\
\hline $\mathrm{p}$ & $<0.0005$ & Time since rehabilitation & 0.048 & $1.2 \%$ \\
\hline \multicolumn{2}{|c|}{ Domain 4: 'Getting along' } & FIM Self-care & 0.004 & $5 \%$ \\
\hline $\mathrm{R}^{2}$ & $28.0 \%$ & FIM Communication & 0.002 & $5.5 \%$ \\
\hline $\mathrm{F}$ & $4.5(17,155)$ & FIM Social Cognition & 0.099 & \\
\hline $\mathrm{p}$ & $<0.0005$ & Diagnosis & 0.087 & \\
\hline & & Age & 0.034 & $1.9 \%$ \\
\hline & & Gender & 0.001 & $6.1 \%$ \\
\hline & & Language & 0.003 & $4.3 \%$ \\
\hline & & Education & 0.196 & \\
\hline \multicolumn{2}{|c|}{ Domain 5: 'Life activities Part 1' } & FIM Selfcare & 0.080 & $1.5 \%$ \\
\hline $\mathrm{R}^{2}$ & $28.0 \%$ & Sphincter & 0.153 & $0.9 \%$ \\
\hline $\mathrm{F}$ & $7.3(10,162)$ & Communication & 0.067 & $1.7 \%$ \\
\hline \multirow[t]{4}{*}{$\mathrm{p}$} & $<0.0005$ & Work & 0.004 & $3.7 \%$ \\
\hline & & Age & 0.097 & \\
\hline & & Preferred language & 0.009 & $2.9 \%$ \\
\hline & & $\begin{array}{l}\text { Time between onset of } \\
\text { stroke and rehabilitation }\end{array}$ & 0.120 & \\
\hline \multicolumn{2}{|c|}{ Domain 5: 'Life activities Part 2'* } & FIM Locomotion & $<0.0005$ & $24.7 \%$ \\
\hline $\mathrm{R}^{2}$ & $39.7 \%$ & Age & 0.191 & \\
\hline $\mathrm{F}$ & $8.7(4,48)$ & Language & 0.026 & $5.9 \%$ \\
\hline $\mathrm{p}$ & $<0.0005$ & & & \\
\hline \multicolumn{2}{|c|}{ Domain 6: 'Participation' } & FIM Locomotion & $<0.0005$ & $7.9 \%$ \\
\hline $\mathrm{R}^{2}$ & $35.9 \%$ & Work & $<0.0005$ & $7.6 \%$ \\
\hline $\mathrm{F}$ & $12.8(7,149)$ & Preferred language & $<0.0005$ & $10.9 \%$ \\
\hline \multirow[t]{3}{*}{$\mathrm{p}$} & $<0.0005$ & Place of living & 0.110 & \\
\hline & & Living situation & 0.044 & $1.4 \%$ \\
\hline & & $\begin{array}{l}\text { Time between onset of } \\
\text { stroke and rehabilitation }\end{array}$ & 0.054 & \\
\hline \multicolumn{2}{|l|}{ WHODAS 2.0 Total } & FIM Self-care & $<0.0005$ & $6.2 \%$ \\
\hline $\mathrm{R}^{2}$ & $40.8 \%$ & FIM Communication & 0.027 & $2.3 \%$ \\
\hline $\mathrm{F}$ & $12.2(9,147)$ & Work & 0.001 & $4.9 \%$ \\
\hline \multirow[t]{4}{*}{$\mathrm{p}$} & $<0.0005$ & Time since rehabilitation & 0.040 & $1.4 \%$ \\
\hline & & Age & 0.026 & $1.7 \%$ \\
\hline & & Preferred language & 0.002 & $3.7 \%$ \\
\hline & & $\begin{array}{c}\text { Time between onset of } \\
\text { stroke and rehabilitation }\end{array}$ & 0.024 & \\
\hline
\end{tabular}


Results of standard multiple regression analysis

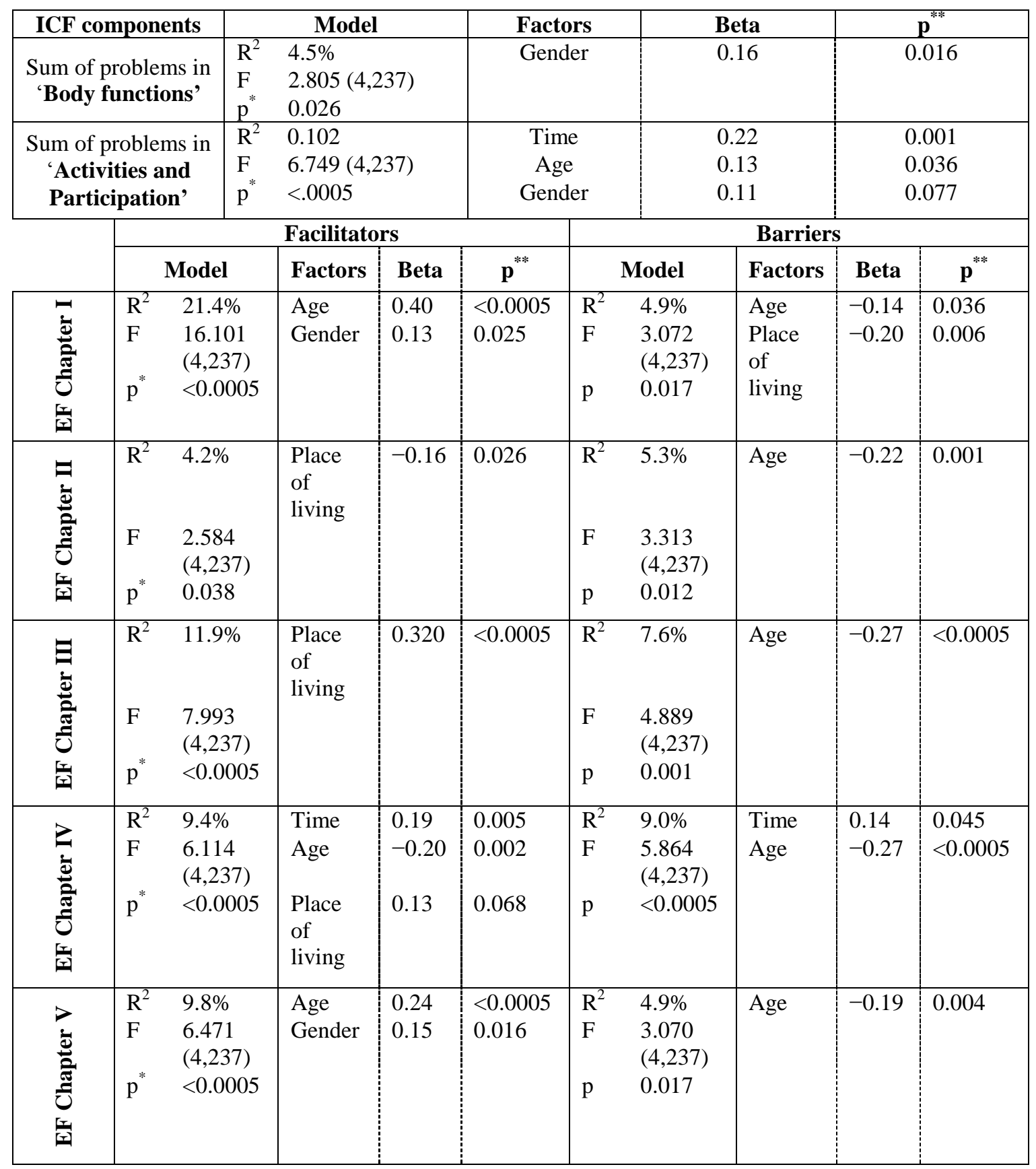

EF: environmental factors; $\mathrm{p}^{*}$ : statistical significance of the model; $\mathrm{p}^{* *}$ : statistical significance of each variable of the model. 
Results of direct logistic analysis for seven chosen categories of the ICF

\begin{tabular}{|c|c|c|c|c|c|c|c|c|c|c|}
\hline \multirow{2}{*}{$\begin{array}{l}\mathrm{ICF} \\
\text { code }\end{array}$} & \multirow{2}{*}{\multicolumn{2}{|c|}{ ICF category title }} & & & & $\mathrm{B}$ & $\mathrm{P}^{* * *}$ & Odds & \multicolumn{2}{|c|}{$95 \% \mathrm{CI}$ for OR } \\
\hline & & & & & & & & $\begin{array}{l}\text { Ratio } \\
\text { (OR) }\end{array}$ & Lower & Upper \\
\hline \multirow[t]{3}{*}{$\mathrm{d} 460$} & \multirow{3}{*}{\multicolumn{2}{|c|}{$\begin{array}{l}\text { 'Moving around in } \\
\text { different locations' }\end{array}$}} & $\chi^{2}$ & $\begin{array}{l}32.1 \\
(4, \mathrm{~N}=238)\end{array}$ & age & 0.05 & $<0.0005$ & 1.06 & 1.03 & 1.08 \\
\hline & & & $\mathrm{p}^{*}$ & $<0.0005$ & & & & & & \\
\hline & & & $\begin{array}{l}\text { Correctly } \\
\text { classified }\end{array}$ & $75.2 \%$ & & & & & & \\
\hline \multirow[t]{4}{*}{$\mathrm{d} 530$} & \multirow{4}{*}{\multicolumn{2}{|c|}{ 'Toileting' }} & $\chi^{2}$ & 29.1 & time & 0.01 & 0.033 & 1.01 & 1.00 & 1.02 \\
\hline & & & & $(4, N=226)$ & age & 0.05 & 0.002 & 1.05 & 1.02 & 1.08 \\
\hline & & & $\mathrm{p}^{*}$ & $<0.0005$ & $\operatorname{sex}$ & -0.58 & 0.090 & 0.56 & 0.29 & 1.09 \\
\hline & & & $\begin{array}{l}\text { Correctly } \\
\text { classified }\end{array}$ & $74.3 \%$ & living & -0.82 & 0.033 & 0.44 & 0.21 & 0.94 \\
\hline \multirow[t]{4}{*}{$\mathrm{d} 540$} & \multirow{4}{*}{\multicolumn{2}{|c|}{ 'Dressing' }} & $\chi^{2}$ & 34.94 & time & 0.01 & 0.049 & 1.01 & 1.00 & 1.02 \\
\hline & & & & $(4, N=233)$ & age & 0.04 & 0.003 & 1.01 & 1.01 & 1,06 \\
\hline & & & $\mathrm{p}^{*}$ & $<0.0005$ & living & $-1,04$ & 0.003 & 0.35 & 0.18 & 0.71 \\
\hline & & & $\begin{array}{l}\text { Correctly } \\
\text { classified }\end{array}$ & $69.5 \%$ & & & & & & \\
\hline \multirow[t]{4}{*}{ d640 } & \multirow{4}{*}{\multicolumn{2}{|c|}{ 'Doing housework' }} & $\chi^{2}$ & 39.7 & time & 0.02 & 0.022 & 1.02 & 1.00 & 1.03 \\
\hline & & & & $(4, \mathrm{~N}=231)$ & age & 0.04 & 0.003 & 1.04 & 1.01 & 1.06 \\
\hline & & & $\mathrm{p}^{*}$ & $<0.0005$ & $\operatorname{sex}$ & 0.66 & 0.043 & 1,94 & 1,02 & 3,67 \\
\hline & & & $\begin{array}{l}\text { Correctly } \\
\text { classified }\end{array}$ & $75.8 \%$ & living & -1.04 & 0.013 & 0.24 & 0.08 & 0.74 \\
\hline \multirow[t]{4}{*}{ d920 } & \multirow{4}{*}{\multicolumn{2}{|c|}{ 'Recreation and leisure' }} & $\chi^{2}$ & 22.5 & age & 0.03 & 0.008 & 1.03 & 1.01 & 1.052 \\
\hline & & & & $(4, \mathrm{~N}=219)$ & living & -1.03 & 0.023 & 0.358 & 0.148 & 0.867 \\
\hline & & & $\mathrm{p}^{*}$ & $<0.0005$ & & & & & & \\
\hline & & & $\begin{array}{l}\text { Correctly } \\
\text { classified }\end{array}$ & $63.9 \%$ & & & & & & \\
\hline \multirow[t]{4}{*}{ e210 } & \multirow[t]{4}{*}{$\begin{array}{l}\text { 'Physical } \\
\text { geography' }\end{array}$} & Facilitators & $\begin{array}{l}\chi^{2} \\
\mathrm{p}\end{array}$ & $\begin{array}{l}9.3 \\
(4, \mathrm{~N}=210) \\
0.054\end{array}$ & & & & & & \\
\hline & & Barriers & $\chi^{2}$ & $\begin{array}{l}12.2 \\
(4, \mathrm{~N}=210)\end{array}$ & living & -1.52 & 0.004 & 0.22 & 0.08 & 0.61 \\
\hline & & & $\mathrm{p}^{*}$ & 0.016 & & & & & & \\
\hline & & & $\begin{array}{l}\text { Correctly } \\
\text { classified }\end{array}$ & $89 \%$ & & & & & & \\
\hline \multirow[t]{5}{*}{ e310 } & \multirow{5}{*}{$\begin{array}{l}\text { 'Immediate } \\
\text { family' }\end{array}$} & Facilitators & $\chi^{2}$ & 18 & age & 0.04 & & 1.04 & 1.04 & 1.08 \\
\hline & & & & $(4, \mathrm{~N}=216)$ & living & 2.11 & 0.000 & 8.25 & 2.86 & 23.80 \\
\hline & & & $\mathrm{p}^{*}$ & 0.001 & & & & & & \\
\hline & & & $\begin{array}{l}\text { Correctly } \\
\text { classified }\end{array}$ & $88.4 \%$ & & & & & & \\
\hline & & Barriers & $\begin{array}{l}\chi^{2} \\
p^{*}\end{array}$ & $\begin{array}{l}3.5 \\
(4, \mathrm{~N}=216) \\
0.470\end{array}$ & & & & & & \\
\hline
\end{tabular}




\subsection{Results of Part 4}

Detailed results of unique contribution of four personal factors (time since rehabilitation, age, gender and place of living) to the results of WHODAS 2.0 are showed in the Table 5.7. At least one of the factors was important in almost every domain and total score of WHODAS 2.0. Age was statistically significant factor in predicting outcome in 'Mobility' and 'Getting along' domains, as well as in the total score of WHODAS 2.0. Place of living was the factor that did not show statistically significant contribution to the outcome.

Table 5.7

Unique contribution of time since rehabilitation, age, gender and place of living to WHODAS 2.0 in Latvian population

\begin{tabular}{|c|c|c|c|c|c|c|c|c|}
\hline & \multicolumn{2}{|c|}{$\begin{array}{l}\text { Time since } \\
\text { rehabilitation }\end{array}$} & \multicolumn{2}{|c|}{ Age } & \multicolumn{2}{|c|}{ Gender } & \multicolumn{2}{|c|}{ Place of living } \\
\hline & $\begin{array}{c}\mathrm{B} \\
(95 \% \mathrm{CI})\end{array}$ & $\mathrm{p}$ & $\begin{array}{c}\mathrm{B} \\
(95 \% \mathrm{CI})\end{array}$ & $\mathrm{p}$ & $\begin{array}{c}\mathrm{B} \\
(95 \% \mathrm{CI})\end{array}$ & $\mathrm{p}$ & $\begin{array}{c}\mathrm{B} \\
(95 \% \mathrm{CI})\end{array}$ & $\mathrm{p}$ \\
\hline 'Cognition' & - & - & - & - & $\begin{array}{c}7.1 \\
(-0.05-14.2)\end{array}$ & 0.05 & - & - \\
\hline 'Self-care' & $\begin{array}{c}0.4 \\
(0.0-0.8)\end{array}$ & 0.05 & - & - & - & - & - & - \\
\hline 'Mobility' & - & - & $\begin{array}{c}0.4 \\
(0.1-0.7)\end{array}$ & 0.01 & - & - & - & - \\
\hline 'Getting along' & - & - & $\begin{array}{c}0.33 \\
(0.0-0.6)\end{array}$ & 0.03 & $\begin{array}{c}15.0 \\
(6.6-23.4)\end{array}$ & 0.001 & - & - \\
\hline $\begin{array}{r}\text { 'Life activities' } \\
\text { Part } 1\end{array}$ & - & - & $\begin{array}{c}0.3 \\
(-0.1-0.7)\end{array}$ & 0.10 & - & - & - & - \\
\hline $\begin{array}{r}\text { 'Life activities' } \\
\text { Part } 2\end{array}$ & - & - & $\begin{array}{c}0.4 \\
(-0.2-1.0)\end{array}$ & 0.19 & - & - & - & - \\
\hline 'Participation' & - & - & - & - & - & - & $\begin{array}{c}5.5 \\
(-1.3-12.2)\end{array}$ & 0.11 \\
\hline $\begin{array}{r}\text { Total } \\
\text { WHODAS } 2.0\end{array}$ & $\begin{array}{c}0.3 \\
(0.0-0.6)\end{array}$ & 0.04 & $\begin{array}{c}0.3 \\
(0.0-0.5)\end{array}$ & 0.03 & - & - & - & - \\
\hline
\end{tabular}




\section{DISCUSSION}

The results of this research shows that different aspects of WHO's bio-psycho-social model influence rehabilitation outcomes for persons after stroke and results depends on the country of residence (Latvia or Sweden). Functional, organizational, social and personal factors are of importance. Some of the factors are modifiable by the healthcare system, but some are the responsibility of society as a whole.

\subsection{Functional outcomes of in-patient rehabilitation after stroke in Latvia and Sweden}

When theoretically comparing stroke care systems in Latvia and Sweden it seems that the components of stroke care are similar. They also seem to be in line with the suggestions of European Union of Medical Specialists Section of Physical and Rehabilitation Medicine. (Gutenbrunner et al., 2010) However, both populations vary in their basic medical and sociodemographic characteristics, as well as in the level of independence at admittance and discharge. This suggests that there are potential differences in its content and organizational aspects of rehabilitation.

\subsubsection{Differences in two stroke care systems}

In both countries, Latvia and Sweden, in-patient rehabilitation is organised through a multi-professional team, with nursing and medical care available 24 hours a day. However, information about the exact content of rehabilitation and its intensity is lacking in both countries. There still are no agreed selection criteria for in-patient rehabilitation. So the decision whether to admit a patient or not to the rehabilitation facility is made by rehabilitation specialists in both countries. Also the funding of in-patient care comes both from the public purse and from contributions from the patients themselves in Latvia as well as in Sweden. Additionally, according to the World Bank reported data from 2013, the gross domestic product in Sweden was 4.2 times higher than in Latvia. Therefore, the cost to patients in Latvia places a higher financial burden on affected families. Thus, the patient's cost for rehabilitation at an in-patient facility per day, when comparing this to average wages of each country, is proportionately different between Latvia and Sweden, with higher percentage costs for people in Latvia. While in Sweden this fee might serve as motivation for participation in the rehabilitation process, in Latvia it could be the reason behind a family's decision to decline this service. 
In Latvia, for certain categories (such as status of severe disability or low income), all patient's cost is covered by public resources. This can provide an explanation for possible differences in the incentive for rehabilitation. The CERISE study has previously underlined that selection criteria for rehabilitation are not solely clinical and could depend on organizational and financial aspects. (Putman and De Wit, 2009)

The organization of acute care is important because this is where stroke rehabilitation starts. In Sweden, almost all patients after stroke are treated in stroke units. (Appelros et al., 2014) In Latvia, the information for the percentage of patients treated in a stroke unit in not available. Without clear and precise measurement and assessment of stroke care pathways, persons who likely would benefit from in-patient rehabilitation may end up excluded from rehabilitation. Systematic and standardised data collection could provide reliable information for comparing different systems thus avoiding speculations on the quality and efficacy of the services.

\subsubsection{Differences in socio-demographic data}

The two most prominent differences between the populations were the length of rehabilitation, and the time between onset of stroke and admittance to rehabilitation.

The contrast between the lengths of rehabilitation in both study populations is large. In the Latvian population, the duration of in-patient rehabilitation is approximately two weeks and is relatively fixed. The median length of stay in Sweden, even when compared to other countries, is rather long. (Atalay and Turhan, 2009; Grant et al., 2014) The length of rehabilitation cannot be used as a tool to describe clinical success. According to accepted standards of rehabilitation, the rehabilitation plan should be individualized and based on the expected improvement, which is not time limited. ( PRM, Section of UEMS, 2006) However, time is used as a tool to estimate the costs of the health care process and in some countries can be used to limit the amount of rehabilitation. (Atalay and Turhan, 2009)

While most of the patients in Sweden were admitted to rehabilitation within the first month after the event, patients in Latvia usually started after 2 to 3 months. These figures are in favour of the Swedish system, since the best results can be achieved at earlier phases after stroke onset. (M. J. Meyer et al., 2014; Quinn et al., 2009b) There is also no data on whether persons after stroke in Latvia received treatment in the period between acute care and being admitted to rehabilitation. There are several options available: rehabilitation in the home, privately funded rehabilitation at in- or outpatient wards, day care units or no formal rehabilitation and the pathway is not known. 


\subsubsection{Differences in functional dependence at the discharge}

The Latvian population were more independent at the time of admission and discharge. But the shift between proportions of the levels of dependence from admittance to discharge is more notable in the Swedish population. However, improvement was statistically significant in both populations, showing that the interventions had an effect.

Considering the level of independence at admittance to rehabilitation, the patients in Sweden were more likely to improve. This advantage of Swedish stroke population slightly decreased when adjusting for age, time since onset and length of rehabilitation. These factors have previously shown as significant predictors of rehabilitation effectiveness and efficacy.(Koh et al., 2012) However, they explained rather small part of differences between countries indicating, that there is other factors that should be considered as significant. The intensity (Putman et al., 2006) and content (De Wit et al., 2006) of rehabilitation could explain the variance of outcomes. However, none of this information was available for current analysis, which is the limitation of this study.

Since the Latvian population was more independent at admittance, there is a possibility that improvement during rehabilitation is not detected due to a ceiling effect of the FIM. Thus, FIM does not reflect actual gain of rehabilitation due to difference of rehabilitation aims in Latvia, compared to ones in Sweden. The goals of the process and the achievement of them is not available in any of study populations, which is also a global problem (Hakkennes et al., 2011)This, in turn, highlights the need for the assessment tools that reflect clinically meaningful changes during the process. (Beninato et al., 2006; Kucukdeveci et al., 2011)

\subsection{Self-perceived level of disability in Latvian population}

The level of independence or amount of care needed in six domains of daily activities was used as explanatory factors in the self-perceived disability in persons living in community. The results suggest that levels of independence in daily activities at discharge from rehabilitation are significant factors that influenced perception of disability in the chronic phase of stroke.

Either 'Self-care' or 'Locomotion', or both were important in explaining all analysed outcomes. Being independent in locomotion is of importance not only for the 'Mobility' domain of WHODAS 2.0, where there is direct theoretical relationship, but it is also related to perception of problems in 'Participation in society', as well as allowing those who are employed to be able to work. 
These results are in line with recently published part of the CERISE study (Stummer et al., 2015) that also suggests better participation outcomes for those who are more independent early after stroke. They are also in line with overall principles of physical and rehabilitation medicine. The process of medical rehabilitation directly after stroke is oriented to the medical assessment and the functional aspects and focuses mainly on the improvement of independence in basic daily activities. These aspects, in turn, give a basis for better participation in society (Mayo et al., 2014; Skolarus et al., 2014), and, thereby, on quality of life. Moreover, enabling person's ability to live a meaningful life according to his/her wishes is the overall goal of rehabilitation. ( PRM, Section of UEMS, 2006)

However, the ability to perform activities independently cannot give the whole picture of the disability experience. (Mayo et al., 2014) Other factors, such as social and personal ones, are of similar importance. Functional, social and personal factors chosen for the analysis could explain up to almost half of the variance in a person's experience of life after stroke, depending on the analysed life aspect. These factors explained such domains as 'Mobility' and 'Self-care' rather well. Both these domains represent the issues of basic skills of physical functioning. The models explained considerably less well the perception of 'Understanding and Communication', as well as 'Interaction with other people'. These tasks require complicated multilevel skills that are more challenging to evaluate than physical functioning. Persons after stroke could experience failure by health professionals to identify those needs. (Peoples et al., 2011) Non-physical aspects of stroke consequences has been described as less related to stroke severity and recognized as more important from perspective of stroke patients. (Owolabi, 2011)

'Participation in society' was also rather poorly explained in comparison to other domains. Moreover this domain, along with 'Household activities', was reported as most problematic for the study population. That is of interest and importance because participation in society involves the usage of complex skills and navigation in everyday live.

\subsection{The role of personal factors}

Age and gender as socio-demographic factors are mentioned in the definition of personal factors in the framework of ICF. Even though they are not classified in the ICF, they might influence the domains, as shown in this study. Factors such as place of residence and time since onset seem to not be mentioned in a review that dealt with personal factors (Geyh et al., 2011), although they are not classified under any other components of ICF. The results of Part 3 of the study suggest that personal factors such as age, gender, place of residence and 
time since onset of stroke can influence self-perceived functioning and environmental factors defined in the framework of the ICF is persons living in Sweden.

The chosen personal factors model showed a predictive value in functioning and environmental factors. The two highest predictive values in this model were noted foremost for environmental factors (facilitators of 'products and technology' and 'support and relationships') and then for number of restrictions in 'activities and participation'. All other groups analysed also showed statistically significant predictive values. These results are supported by other studies in terms of emphasizing that modifying environmental factors can be beneficial for stroke patients in the chronic phase, while approaches at other levels of individuals' problems are more likely to fail to achieve any satisfactory goal. (Alguren et al., 2012; Bouffioux et al,. 2011; Goljar et al., 2011).

'Physical geography' and 'design, construction and building products and technology of building for public use' were the most commonly recognized barriers, notwithstanding that neither even reached the $10 \%$ threshold in this study. These results are unexpected for the category of 'physical geography', firstly because of the hilly characteristics of the region in which most of the study population lived and, secondly, since the patients in this study are mainly from the same part of Sweden as in the study of Algurén et al. (Alguren et al., 2009), where there is a difference in the results. In Algurén et al.'s study of self-reported changes in barriers and facilitators of environmental factors in a similar population of stroke patients in Sweden, more than half of the patients, three months after the stroke, mentioned 'physical geography' as a problem. However, this cohort of patients had lived longer with their condition after the stroke and, as the environment is persistent and not changeable, patients no longer recognize it as a problem after a while. New experiences and changes in expectations can lead to reprioritization, recalibration and reconceptualization, called response shift, of a set of problems that a person meets in his/her daily life. This at least seems to be implied in changes in self-perceived physical functions among stroke patients. (Barclay-Goddard et al., 2011)

Seven selected categories were analysed in this part of the study: five in the components of 'activities and participation' and two in environmental factors. The model of personal factors was found to have highly significant relations to all five domains of 'activities and participation'. For environmental factors, this model was seen to be significant only for barriers in 'physical geography' and facilitators for 'immediate family', which is understandable, because both 'immediate family' as a barrier and 'physical geography' as a facilitator are considered only in exceptional cases. 
Although this model of personal factors showed an influence of all the components, domains and categories that were used for analysis, the influence of each single factor and interaction of these factors differed widely between different components, domains and categories. For example, the domain of 'moving around in different locations' was found to be only little influenced by age, whereas 'doing housework' was influenced by a combination of all the factors selected in this study.

Four personal factors were included in the analysis of outcomes Part 2 of this study. However, it is impossible to perform a direct comparison of outcomes in the ICF component of 'Activities and Participation' between Latvia and Sweden. The concept of outcome is the same, but different assessment tools have been used, which could lead to bias of interpretation of results. (Stallinga et al., 2014) Aspect that also could lead to presentation of different influence of the factors is the method used for statistical analysis. While in the Swedish population, pure statistical influence of factors was explored, in the Latvian population, the results were controlled for other factors, such as level of independence at discharge and working status. That could also lead to differences in results in both populations.

However, there were some similarities in the results. Time since rehabilitation, age and gender where significant factors also in the model that evaluated problems in 'Activities and Participation' using WHODAS 2.0 in stroke population in Latvia. But in both populations the role of those factors where rather small. More time spent living in community and higher age where related to more problems reported in different aspects of 'Activities and Participation' in both populations. But place of living turned to be a factor that has no significant influence on self-perceived functioning, when controlling for other significant factors.

\subsubsection{Age}

Age had the greatest influence of all the components, domains and categories of ICF selected for analysis in Swedish population. Age was shown to influence a number of problems and all of the chosen categories of 'activities and participation' and almost all the domains of environmental factors, except for the reporting of 'physical geography' as a barrier. Reporting barriers in 'natural environment and human made changes to environment', 'support and relationships' and both facilitators and barriers in 'products and technology', as well as 'attitudes' was more common among between younger patients.

Age was also most prominent between chosen personal factors in explaining selfreported disability in the Latvian population. Reporting restrictions in 'activities and 
participation' was more typical in older patients in both studies. That is in line with other studies that has shown the importance of age as a factor in the functional outcome of stroke. (Carod-Artal et al., 2005; Carod-Artal and Egido, 2009; Knoflach et al., 2012; Meyer et al., 2014)

\subsubsection{Gender}

Meyer et al. (Meyer et al., 2014) reported that gender has been presented as a significant factor for predicting outcome after stroke in less than one out of four cases. Some studies explain gender differences in stroke outcome by a greater average age in women who suffer a first ever stroke (Eriksson et al,. 2009; Kelly-Hayes et al., 2003) and by a lower level of consciousness on admission. (Eriksson et al., 2009) There is also contradictory information on the differences in discharge destination between males and females. (Nguyen et al., 2015; Pereira et al., 2014) Findings in studies based on the Swedish stroke population that suggest that there are certain differences that might be explained by biological, epidemiological and clinical factors. (Roding et al., 2010)

In the Swedish population in the current study, gender has shown significant relation to 'doing housework'. In the population living in Latvia, males have reported more problems in domains of 'cognition 'and 'interaction to other people'. Although, in different aspects of functioning both populations have had a results that are against the gender differences in the studies mentioned above (Eriksson et al., 2009; Feigin et al., 2010; Kelly-Hayes et al., 2003; Pereira et al., 2014; Roding et al., 2009; Roding et al., 2010) in which men had been prone to have a better outcome. It is interesting that most of the differences considered to be gender specific are assessed using self-perceived questionnaires. (Feigin et al., 2010; Roding et al., 2009) That would suggest social distinction as an important factor in differences between males and females.

\subsubsection{Place of living}

There could be disparities between rural and urban environments in terms of stroke care.(Phipps et al., 2014) It has been described as a factor for successful functional outcomes (Leira et al., 2008) because of the accessibility and organization of stroke care. (Cadilhac et al., 2011; Rodriguez et al., 2011) In Sweden nearly all persons who require treatment in a stroke unit do receive it. (Appelros et al., 2014) Thus, accessibility to organised stroke care should not be a problem in this population. However, it could be thought that living in a rural region or living in a city makes a great difference in daily living, society and physical 
environment, and can offer unique experience that can lead to different attitudes and treatments on person's condition, skills and environment, therefore affecting overall functioning. (Corrigan and McBurney, 2012)

In the Swedish population, most of environmental factors where recognised as facilitators or barriers differently depending on the area person were living in. Having facilitators in 'natural environment and human made changes in environment' was reported more often by those living in a rural setting, but facilitators in 'support and relationships' and 'attitudes' reported by those living in a city. It was five times more common to see 'physical geography' as a barrier among people who lived in the city. This phenomenon could be explained by differences in the objective geography of the place of residence, or by different personal attitudes to the environment. 'Immediate family' as a facilitator was mentioned much more often by those who lived in a rural setting. In rural areas, a person could be much more closely connected to the family than may be the case in the city when the family does not live in the near vicinity or where other care providers are available.

Single categories in 'activities and participation' ('toileting', 'dressing', 'doing housework' and 'recreation and leisure') were influenced by place of residence in Swedish population, indicating that those who lived in the city more often recognized this as a problem. That indicates a diversity, which is related to subjective reasons (such as self-image and demands) rather than to objective barriers in the environment.

Unlike persons living in Sweden, persons living in Latvia did not differ significantly in perception of problems in functioning due to place of living. That could be due peculiarities of the aspects of health and social care after stroke or less discrepancies in social aspects between persons in study population. The use of more complex model in statistical analysis could also explain the lack of the predictive value of place of living in the Latvian population.

\subsubsection{Time since onset}

In the Swedish population, longer the time that had elapsed since the stroke event, the less problems in 'activities and participation', as well as 'attitudes' as facilitators were reported. Similar results showed persons after stroke in Latvia, reporting more problems in 'self-care' and total score of WHODAS 2.0 with time. However, this factor showed also some influence on 'dressing', 'toileting' and 'doing housework', in persons living in Sweden and there the results were contrary and tended to increase with time.

Time is a factor that has a rather strong theoretical role in the experience of disability. (Jahiel and Scherer, 2010) However, the evidence for it is controversial. Most effective time 
for rehabilitation is the first months after the stroke, especially the first month. (Verheyden et al., 2008) However, part of persons can gain some of skills after this period as well (Kwakkel et al., 2004). There is some evidence that perception of disability can change with time (Barclay-Goddard et al., 2011; Thoren-Jonsson 2001). White et al. (White et al., 2007) reported that the functioning of stroke survivors change significantly over time and social support and social services is also of importance. But Meyer et al. (Meyer et al., 2015) showed that the functional and motor outcomes did not differ between 2 months and 5 years after stroke.

The results of this study suggest perception of problems in 'activities and participation' component of ICF changes with a time. However, the role of this dynamic factor, if compare to other factors in the model, is rather small in both populations. Moreover, this is a cross-sectional study and there is an equal probability that results are due to a shift in perception or randomization of results. Therefore, it is likely that the time that has passed after the disabling event is not a factor in and of itself, but gives a frame of reference in which the changes occur.

\subsection{Work and preferred language}

Work and preferred language to fulfill the questionnaire were two additional factors in the results of Part 2 of this study. These aspects are worth to discuss because of their theoretical importance of social functioning and statistical importance of the model.

Work had the highest unique contribution in total score of WHODAS 2.0, as well as domains in 'Self-care' and 'House-hold activities', when controlling for other important factors. It aso had remarkable role in explaining variance of 'Cognition', 'Mobility' and Participation domains. It has been suggested that returning to work could lead to more positive health outcomes and quality of life (Carlier et al., 2013) and most probably it does not depend on the work load (part or full time employment). (Pack et al., 2014) The ability to return to work after experiencing a disabling condition is in interests of politicians and decision makers for its contribution to the economy. Work is amongst the most important meaningful activities of the lives of many people (Barclay-Goddard et al., 2012). It is also of great importance in the Latvian society and not only for those of working age due to both financial and social reasons (McKevitt et al., 2003). The person who works has a clearly defined role that allows him/her to make a meaningful contribution to society.

There was also an obvious discrepancy between the persons, depending on the language they preferred. Those who choose to fill out the questionnaire in Russian, 
experienced greater problems in self-perceived disability in the 'Participation' domain versus those who preferred Latvian. The level of dependence at discharge did not differ between the two groups. Thus, the difference cannot be explained by the poorer neurologic outcomes after stroke. (Burke et al., 2014; Lisabeth et al., 2014) Since the language of use does not directly influence an outcome of disability perception, the differences could be explained by diversity in health behavior (Kasmel et al., 2004) or "socio-cultural" explanations such as organizational barriers of healthcare and issues in the communication between healthcare professionals and patients. (Betancourt et al., 2003)

\subsection{Methodological considerations and Limitations}

Observational (non-experimental) design of the study has been chosen for framework of this thesis. Considering the nature of rehabilitation, other types of research could fail in answering the current research questions. Rehabilitation as a complex intervention (Quinn et al., 2009b) includes number of interactions between different components. (P. Craig et al., 2008) The key components is patient characteristics, all treatment and care process, as well as variability of outcomes. (P. Craig et al., 2008; Horn et al., 2005) Associations between these components are complicated, thus it is rather challenging to report the effectiveness of everyday practice. (P. Craig et al., 2008; L. E. Craig et al., 2014; Datta and Petticrew, 2013) However, this information is necessary, in order to compare results between settings and, therefore, seek for optimal models for stroke rehabilitation. (De Wit et al., 2007)

The critics that could be addressed for the observational studies include the lack of confidence that evidence is based on causal relationships rather than accidental associations due to other reasons. (Horn et al., 2005)To address this issue, the case-mix adjustment was used in the Part 1 and Part 2 of the study to control for possible confounding factors. (P. Craig et al., 2008; Teale et al., 2012) There have been attempts to find standardized model for confounders in stroke outcomes. (Berlowitz and Stineman, 2010; Segal and Whyte, 1997; Teale et al., 2012) However, these models mainly address such outcomes as mortality and dependency. (Teale et al., 2012) Therefore, it is now suggested that it is better to treat confounders according to the individual needs of the study than use standardized model of it. (Garofolo et al., 2013) This approach was also the used in Part 1 and Part 2 of the current study.

Another issue, worth to discuss is the nature and interpretation of outcome measures, that determines the choice of data analysis. Most of the instruments that are used for assessment in rehabilitation contain ordinal data. (Kucukdeveci et al., 2011) There have been 
several widely used approaches for reporting outcomes, such single scale scores, score changes or percentile ranks, based on population norms. However, the interpretation of the outcomes is more mathematical and less focuses on clinically meaningful changes. (Jette et al., 2007) Moreover, it also violates the mathematical assumptions of the outcomes and thus, the conclusions, drawn from them. Hobart (Grimby et al., 2012; Hobart and Cano, 2009) Common way of addressing this problem, is by dichotomisation of the data by using cut-off points (Optimising Analysis of Stroke Trials et al., 2007), that could lead to loose of clinically relevant information and statistical power. (Roozenbeek et al., 2011) Therefore, it was decided to use shift analysis and ordinal regression analysis. (Bath et al., 2012; Saver 2007) Shift analysis so far mainly has been used for mRS, when presenting the outcomes for acute stroke trials. (Avert Trial Collaboration group et al., 2015; Saver, 2007) To avoid violations of the assumptions mentioned before and meanwhile preserve clinical relevance of the outcomes, FIM domains were trichotomized according to level of assistance needed. That is in line with the tasks of in-patient rehabilitation. (Quinn et al., 2009b; Ward et al., 2012) To our knowledge, this type of analysis has not previously been used in a rehabilitation population with clinical data.

Same arguments as for use of the FIM would be valid also for the outcomes of WHODAS 2.0 and ICF Core Set for Stroke. WHODAS 2.0 is self-reported assessment tool and the actual order of response categories is unknown. (Kucukdeveci et al., 2013) Perception of disability experience and recognition of problems can differ between the persons experiencing the condition and the professionals who perform the evaluation (Robinson et al., 2011). That can lead to a random variance due to the personal attitudes towards the situation. However, it has been developed based on extensive review and field-testing procedure (Ustun et al., 2010) and the suggested scoring algorithm was used. (Measuring Health and Disability, 2010) The distribution of residuals in final statistical models was normal and assumptions for analysis were not violated. The bias of results due to usage of two translations of WHODAS 2.0 also cannot be excluded. However, using two translations allowed capturing a realistic picture of the post stroke population living in Latvia, regardless of language preference.

To avoid analysing data that would not represent the actual changes in components of, the qualifiers of the ICF Core Set for stroke were dichotomized. Thus the results show the possibility of having or of not having a problem in a certain domain of functioning by the facilitators or barriers that are reported or of having a number of problems below these levels. It does not say anything about the extent of the problem.

When discussing study limitations, the data gathering procedures need to be mentioned. The data gathering for study population in Latvia was retrospective. The 
evaluation on daily basis is done by rehabilitation professionals from the specialized inpatient rehabilitation unit. Due to the fact that more than one person is assessing patients there is risk of bias in the results generated from this evaluation. However, FIM scoring are detailed and the excellent inter-rater reliability has been reported for the instrument (Ottenbacher et al., 1996) and the ordinal response categories where collapsed. Both those aspects would allow addressing the issue of bias. The participants were included in the study if they were connected to rehabilitation facilities. Since there is possible bias of patient selection, study population may not represent the true population of persons who would benefit from inpatient rehabilitation after stroke.

There was missing data regarding the patients (i.e. stroke-subtypes, smoking) and the content of rehabilitation in the data sets in first part of the study, which might have an impact on the results. The data on content or intensity of rehabilitation interventions was not included in the study. Data on involved specialists and amount of sessions per week was anyhow available in medical records of the Latvian population. Similar information were available in the data set of the Swedish populations, however, for limited number of cases. All these cases were omitted from the study due to early beginning of rehabilitation. In none of populations information on the content of therapies was available.

There was no information available of environmental factors in the Latvian population. Environmental factors are important for functioning (Bostan et al., 2015) and could explain the determinants of observed results. However, due to bi-directional values of environmental factors (as barriers or facilitators) the analysis of it is encumbered. 


\section{CONCLUSIONS}

1. The components of the rehabilitation are reported to be similar in Latvia and Sweden, but there is lack of information on the content of these complex interventions.

2. Characteristics and the outcome of the in-patient rehabilitation are different.

3. Showing improvement during rehabilitation is easier if the patient is more dependent and receives rehabilitation earlier after stroke onset.

4. However, majority of factors that explain the differences in functional outcome after rehabilitation between countries remains unknown.

5. Higher level of independence at discharge from rehabilitation leads to lower levels of self-reported disability in chronic phase of stroke in persons living in Latvia.

6. However, social and personal aspects showed equal contribution to the selfreported disability.

7. Personal factors such as age, gender, place of living and time since onset has a predictive value for functioning and environmental factors for persons in chronic phase of stroke living in Sweden.

8. There are relationships between personal factors as mentioned above and certain categories of functioning and environmental factors.

9. These factors interact to influence self-perceived functional outcome and environmental factors as barriers or facilitators in persons living in Sweden.

10. Age, gender and time since onset are also independent factors that are of importance in predicting the self-reported disability in chronic phase of stroke for persons living in Latvia. However, the perception of problems in functioning does not differ between those living in countryside and those in a city. 


\section{FUTURE CONSIDERATIONS}

This study highlights the importance of multiple aspects of in-patient rehabilitation as a complex intervention. The necessity for a complex approach leads to difficulties and restrictions for comparison of the results of the interventions between populations, which are essential for quality assessment in rehabilitation. Having good data gathering in the acute setting as well as in the rehabilitation setting could make comparisons possible in the future. There is also a need for structured data gathering regarding the content of the complex interventions within stroke rehabilitation, in order to fully evaluate the efficacy. It would also serve as a tool for improvement of quality of care, resource coordination and basis for development of the care process. (Sunnerhagen, 2014)

The results of the present study simultaneously underlines the importance of the rehabilitation process and points out the lack of its ultimate implication on the outcome. The consequences of stroke and its impact on lives depend on a complex entirety that is formed by interactions of different factors. Both modifiable and non-modifiable factors are included.

Therefore, both medical and social systems are important in modification of important factors towards better outcomes and as well as being continuous, the process should be interactive. However, more research is needed to identify other important factors and determine the best approaches for addressing the problems in the most productive manner.

\section{Clinical implications and recommendations}

1. Each patient after stroke should be evaluated for further planning of rehabilitation services at acute stage of stroke.

2. Systematic and standardised data collection procedure with clear and precise measurement and assessment system should be developed and used in national level as a quality register. This would provide reliable information on stroke care pathways, as well as evaluation on quality and efficacy of the services.

3. Since post-acute in-patient rehabilitation after stroke is delivered by a multi-professional team, with nursing and medical care available 24 hours a day, the selection criteria and clear goals for those who receive the service should be developed accordingly:

a. Person should be dependent in basic activities of daily living and mobility and, therefore, in need for constant nursing care; Gained independence in these domains are essential for better long-term outcome after stroke in terms of selfperceived disability. 
b. The need for multi-professional rehabilitation or constant medical care should also be evaluated and justified.

4. Post-acute in-patient rehabilitation should be started as early as possible after stroke, preferably, directly after discharge form acute care hospital, since the best results can be achieved at earlier phases after stroke onset;

5. The length of rehabilitation cannot be fixed and should depend on individual needs and prognosis of the person.

6. The information on content and intensity of rehabilitation programmes should be available for detailed evaluation of efficacy of in-patient rehabilitation;

7. Close collaboration with social services and early planning of social integration options are also essential for the outcome. Special attention should be paid to issues related to return to work. 


\section{PRESENTATIONS ON THE STUDY TOPIC}

- Invited speaker to the 8th Baltic Congress of Neurology in Riga, Latvia, September 2426. Presentation: "Comparing the results of in-patient rehabilitation for persons after stroke in Latvia and Sweden"

- 4th Baltic and North Sea Conference on Physical and Rehabilitation Medicine, Riga, Latvia, September 16-18. Poster presentation: "The importance of being aware of differences when comparing results of stroke rehabilitation in different countries".

- Invited speaker to the 18th Nordic Stroke Congress in Malmö, Sweden, August 26-28, 2015. Presentation: “A comparison of stroke rehabilitation in Latvia and Sweden".

- 9 th World Congress of the International Society of Physical and Rehabilitation Medicine, June 19-23, 2015, Berlin, Germany. Oral presentation "Timing and intensity as determinants for functional gains in persons after ischaemic stroke".

- The European Stroke Organisation Conference, April 17-19, 2015, Glasgow, United Kingdom. Poster presentations: "Be aware of differences when comparing results of rehabilitation in different countries" and "Comparison of rehabilitation outcomes for persons after stroke in Latvia and Sweden; a PhD project".

- $3 d$ Baltic and North Sea Conference on Physical and Rehabilitation Medicine, September 25-27, 2013, Hannover, Germany. Poster presentation: "Exploration of some personal factors with ICF core sets for stroke"

- $\quad 8^{\text {th }}$ Congress of Baltic Association for Rehabilitation, September 19, 2013. Riga, Latvia. Oral presentation: "Exploration of some personal factors with the International Classification of Functioning, Disability and Health core sets for stroke”. 


\section{ACKNOWLEDGEMENTS}

“Nav nekāda lielā lieta peldēt labklājībā, kad viss jau nolikts lìdzsvarā. Grūts ir jaunais. Jaunais ledus. Jaunā gaisma. Jaunās izjūtas."

/Pēters Hēgs/

"It's not difficult to coast along when things are going well, when balance has been established. What's difficult is the new. The new ice. The new light. The new feelings."

/Peter Høeg/

The outcome of my doctoral studies and research work is invaluable in terms of experience and knowledge. This would never have happened without an appropriate environment i.e. support. Therefore, I would like to express my deepest gratitude for all who has contributed to the process in different ways. Specially, I would like to acknowledge:

- Associate Professor Anita Vētra for supervision and support during the research process and through the bureaucratic procedures.

- Colleagues in Rīga Stradiṇš University provided an emotional support and encouragement. Special thanks to Assistant Professors Signe Tomsone and Daina Šmite for sharing experiences.

- Professor Katharina Stibrant Sunnerhagen for opening the doors to the endless research world, encouragement to start the process, supervision and support all the way through.

- The Visby Programme of the Swedish Institute provided one-year scholarship period in the University of Gothenburg in Sweden during which, the publications and thesis were written. The members of "Rehabilitation research lab", Section for Clinical Neuroscience and Rehabilitation, Institute of Neuroscience and Physiology, Sahlgrenska Academy, provided the physical and emotional environment during this period. Especially, I would like to acknowledge Hanna C Persson, Margit Alt-Murphy, Emma Kjörk, Elisabeth Brodin, Åsa Nordin, Arve Ophem, Graciela Rovner, Lena Rafsten and Dongni Johansson.

- Special thanks to my articles' co-authors Markku Paanalahti, Åsa Lundgren-Nilsson and Baiba Smilškalne for help with data gathering, discussions and advices. 
- I also acknowledge the help from Dr. Rita Seske in data gathering and Anita Māra Liepa in data entering in computer.

- Quality register WebRehab Sweden provided the Swedish data on rehabilitation results from all participating centres in entire Sweden. National Rehabilitation Centre "Vaivari" provided data on Latvian population.

- Drs. Anda Nulle, Inga Tanenberga, Illa Mihejeva and Inese Kokare helped with the interpretation of findings.

- Anna Ekman, Irēna Rogovska, Kjell Pettersson and Sara Gustavsson helped with the statistical decisions.

- Thanks to all patients who agreed to participate in the study and all those family members of them, who ensured that they could to do that.

- My most sincere gratitude to my family and friends for not only enduring my chronic physical or mental absence, but also rolling up sleeves for practical help, when needed. My parents' never-ending faith in my abilities and unceasing support prevents me from ever giving up growing. 


\section{REFERENCES}

\section{Recources:}

1. 2011. gada tautas skaitīšanas rezultāti īsumā. Informatīvs apskats. Centrālā statistikas pārvalde, 2011.

2. International Classification of Diseases and Related Health Problems: Tenth Revision. Version for 2010. Geneva: World Health Organization, 2010.

3. International Classification of Functioning, Disability and Health. Geneva: World Health Organization, 2001.

4. International Classification of Impairments, Disabilities and Handicaps. A Manual of classification relating to the consequences of disease. Geneva: World Health Organization, 1980.

5. Mackay, Judith, and George A. Mensah.The atlas of heart disease and stroke. Geneva: World Health Organization, 2004.

6. Measuring Health and Disability. Manual for WHO Disability Assessment Scheldue. WHODAS 2.0. Geneva: World Health Organization, 2010.

7. Nichols M, Townsend N, Luengo-Fernandez R, Leal J, Gray A, Scarborough P, Rayner M, European Cardiovascular Disease Statistics 2012. European Heart Network, Brussels, European Society of Cardiology, Sophia Antipolis, 2012.

8. Noncommunicable Diseases. Country profiles 2014. Geneva, Switzerland: World Health Organization, 2014.

9. The Convention on the Rights of Persons with Disabilities. United Nations: Division for Social Policy and Development Disability United Nations, 2006, http://www.un.org/disabilities/convention/conventionfull.shtml [Last accessed July 15, 2015]

10. VistA System. Functional Independence Measurement (FIM) User Manual Version 1.0 [online text, last accessed June6, 2016], Department of Veterans Affairs. VistA System Design and Development http://www.va.gov/vdl/documents/Clinical/Func_Indep_Meas/fim_user_manual.pdf

11. WHO STEPS stroke manual. The WHO STEPwise approach to stroke survelance, Geneva: World Health Organization, 2006.

12. World Health Statistics 2014, Italy: World Health Organization, 2014a.

13. World Report on Disability. Geneva: World Health Organization, 2011.

\section{Literature:}

14. Braddom, Randall L., Chan, Leighton, and Harrast, Mark A. (2011), Physical medicine and rehabilitation (4th edn.; Philadelphia, PA: Saunders/Elsevier) xxiv, 1506 p.

15. Carter E.R., Lubinsky J., Domholdt E. Rehabilitation Research. Principles and Applications. (4th edn.; St. Louis, Missouri, USA: Elsevier Saunders) 2011, 503.

16. DeLisa, JA, BM, Gans, and NE, Walsh (2005), Physical Medicine and Rehabilitation: principles and practice (II: Lippincott Williams \& Wilkins), 1655-76.

17. Frontera, Walter R. and DeLisa, Joel A. (2010), Physical medicine and rehabilitation : principles and practice (5th edn.; Philadelphia: Lippincott Williams \& Wilkins Health) v. (xxii, 2200, 39p.).

18. Norrving, Bo Oxford textbook of stroke and cerebrovascular disease (Oxford textbook of clinical neurology). Oxford University Press, 2014. 


\section{Periodicals:}

19. Alguren B, Fridbund B, Cieza A, Sunnerhagen K, Christensson L. Factors associated with health related quality of life after stroke: a 1-year prospective cohort study. Neurorehabilitation and neural repair. 2012, 26(3), 266-74.

20. Alguren, B., Lundgren-Nilsson, A., and Sunnerhagen, K.S. Functioning of stroke survivors - A validation of the ICF Core Set for stroke in Sweden, Disability and Rehabilitation. 2010, 32(7), 551-59.

21. Alguren, B., Lundgren-Nilsson, A., and Sunnerhagen, K. S. Facilitators and barriers of stroke survivors in the early post-stroke phase. Disabil Rehabil. 2009, 31(19), 1584-91.

22. Ali M, Fulton R, Quinn T, Brady M, Collaboration V. How well do standard stroke outcome measures reflect quality of life? A retrospective analysis of clinical trial data. Stroke, 2013a, 44(11), 3161-5.

23. Ali M, English C, Bernhardt J, Sunnerhagen KS, Brady M, Collaboration VI-R. More outcomes than trials: a call for consistent data collection across stroke rehabilitation trials. Int J Stroke, 2013b, 8(1), 18-24.

24. Alves, I., Fazzi, L., and Griffo, G. Human rights, UN convention, and the International Classification of Functioning, Disability and Health: collecting data on persons with disabilities? Am J Phys Med Rehabil. 2012, 91(13 Suppl 1), S159-62.

25. Appelros P, Jonsson F, Asberg S, Asplund K, Glader EL, Asberg KH, et al. Trends in stroke treatment and outcome between 1995 and 2010: observations from Riks-Stroke, the Swedish stroke register. Cerebrovasc Dis. 2014, 37(1), 22-9.

26. Atalay, A. and Turhan, N. Determinants of length of stay in stroke patients: a geriatric rehabilitation unit experience. Int J Rehabil Res. 2009, 32(1), 48-52.

27. Avert Trial Collaboration group, Bernhardt J, Langhorne P, Lindley RI, Thrift AG, Ellery F, et al. Efficacy and safety of very early mobilisation within $24 \mathrm{~h}$ of stroke onset (AVERT): a randomised controlled trial. Lancet. 2015, 386(9988), 46-55.

28. Ayis S.A., Coker B., Bhalla A., Wellwood I., Rudd A.G., Di Carlo A., et al.Variations in acute stroke care and the impact of organised care on survival from a European perspective: the European Registers of Stroke (EROS) investigators. J Neurol Neurosurg Psychiatry. 2013, 84 (6), 604-12.

29. Banks, J. L. and Marotta, C. A. Outcomes validity and reliability of the modified Rankin scale: implications for stroke clinical trials: a literature review and synthesis. Stroke. 2007, 38 (3), 1091-6.

30. Barclay-Goddard R., Lix L.M., Tate R., Weinberg L., Mayo N.E. Health-related quality of life after stroke: does response shift occur in self-perceived physical function? Arch Phys Med Rehabil. 2011, 92 (11), 1762-9.

31. Barclay-Goddard, R., Ripat, J., and Mayo, N. E. Developing a model of participation poststroke: a mixed-methods approach. Qual Life Res. 2012, 21 (3), 417-26.

32. Barnes C, Sheldon A. Disability, politics and poverty in a majority world context. Disability \& Society. 2010, 25 (7), 771-82.

33. Bath P.M., Lees K.R., Schellinger P.D., Altman H., Bland M., Hogg C., et al. Statistical analysis of the primary outcome in acute stroke trials. Stroke. 2012, 43 (4), 1171-8.

34. Beninato M., Gill-Body K.M., Salles S., Stark P.C., Black-Schaffer R.M., Stein J. Determination of the minimal clinically important difference in the FIM instrument in patients with stroke. Arch Phys Med Rehabil. 2006, 87 (1), 32-9.

35. Berlowitz, D. R. and Stineman, M. Risk adjustment in rehabilitation quality improvement. Top Stroke Rehabil. 2010, 17 (4), 252-61.

36. Berzina G., Sveen U., Paanalahti M., Sunnerhagen KS. Analysing the modified rankin scale using concepts of the international classification of functioning, disability and health. Eur $J$ Phys Rehabil Med. 2015, 52(2) 203-13.

37. Betancourt J.R., Green A.R., Carrillo J.E., Ananeh-Firempong O. Defining cultural competence: a practical framework for addressing racial/ethnic disparities in health and health care. Public Health Rep. 2003, 118 (4), 293-302.

38. Bohannon, R. W. and Smith, M. B. Interrater reliability of a modified Ashworth scale of muscle spasticity. Phys Ther. 1987, 67 (2), 206-7. 
39. Bostan C., Oberhauser C., Stucki G., Bickenbach J., Cieza A. Which environmental factors are associated with lived health when controlling for biological health? - a multilevel analysis. BMC Public Health. 2015, 15, 508.

40. Bostan, C., Oberhauser, C., and Cieza, A. Investigating the dimension functioning from a condition-specific perspective and the qualifier scale of the International Classification of Functioning, Disability, and Health based on Rasch analyses. Am J Phys Med Rehabil. 2012, 91 (13 Suppl 1), S129-40.

41. Bouffioulx, E., Arnould, C., and Thonnard, J. L. Satisfaction with activity and participation and its relationships with body functions, activities, or environmental factors in stroke patients. Arch Phys Med Rehabil. 2011, 92 (9), 1404-10.

42. Brott T., Adams H.P., Jr., Olinger C.P., Marler J.R., Barsan W.G., Biller J., et al.. Measurements of acute cerebral infarction: a clinical examination scale. Stroke. 20 (7), 1989, 864-70.

43. Burke J.F., Freedman V.A., Lisabeth L.D., Brown D.L., Haggins A., Skolarus L.E. Racial differences in disability after stroke: results from a nationwide study. Neurology. 2014, 83 (5), 390-7.

44. Bursac Z., Gauss C.H., Williams D.K., Hosmer D.W. Purposeful selection of variables in logistic regression. Source Code Biol Med. 2008, 3, 17.

45. Cadilhac D.A., Kilkenny M.F., Longworth M., Pollack M.R., Levi C.R. Metropolitan-rural divide for stroke outcomes: do stroke units make a difference?. Intern Med J. 2011,41 (4), 3216.

46. Carlier B.E., Schuring M., Lotters F.J., Bakker B., Borgers N., Burdorf A. The influence of reemployment on quality of life and self-rated health, a longitudinal study among unemployed persons in the Netherlands. BMC Public Health. 2013, 13, 503.

47. Carod-Artal, F. J. and Egido, J. A. Quality of life after stroke: the importance of a good recovery. Cerebrovasc Dis. 2009, 27 Suppl 1, 204-14.

48. Carod-Artal F.J., Medeiros M.S., Horan T.A., Braga L.W. Predictive factors of functional gain in long-term stroke survivors admitted to a rehabilitation programme. Brain Inj. 2005, 19 (9), $667-73$.

49. Catalina-Romero C., Ruilope L.M., Sanchez-Chaparro M.A., Valdivielso P., Cabrera-Sierra M., Fernandez-Labandera C., et al. Factors influencing return-to-work after cerebrovascular disease: the importance of previous cardiovascular risk. Eur J Prev Cardiol. 2015, 22 (9), 1220-7.

50. Cieza A., Ewert T., Ustun T.B., Chatterji S., Kostanjsek N., Stucki G. Development of ICF Core Sets for patients with chronic conditions. J Rehabil Med. 2004, (44 Suppl), 9-11.

51. Cieza A., Geyh S., Chatterji S., Kostanjsek N., Ustun B., Stucki G. ICF linking rules: an update based on lessons learned. J Rehabil Med. 2005, 37 (4), 212-8.

52. Colombetti E., Osimani B., Aluas M., Pessina A., Musio A. Revision of International Classification of Functioning, Disability and Health ethical guidelines: International Classification of Functioning, Disability and Health-related ethical issues. Am J Phys Med Rehabil. 2012, 91 (13 Suppl 1), S155-8.

53. Corrigan, R. and McBurney, H. Community ambulation: perceptions of rehabilitation physiotherapists in rural and regional communities. Physiother Theory Pract. 2012, 28 (1), 107.

54. Cournan, M. Use of the functional independence measure for outcomes measurement in acute inpatient rehabilitation. Rehabil Nurs. 2011, 36 (3), 111-7.

55. Craig L.E., Wu O., Bernhardt J., Langhorne P. Approaches to economic evaluations of stroke rehabilitation. Int J Stroke. 2014, 9 (1), 88-100.

56. Craig P., Dieppe P., Macintyre S., Michie S., Nazareth I., Petticrew M. et al. Developing and evaluating complex interventions: the new Medical Research Council guidance. BMJ. 2008, 337, a1655.

57. Dallmeijer A.J., Dekker J., Roorda L.D., Knol D.L., van Baalen B., de Groot V. et al. Differential item functioning of the Functional Independence Measure in higher performing neurological patients. J Rehabil Med. 2005, 37 (6), 346-52.

58. Damrow J., Gaarder K., Chopra S., Scola G., Bourque K., Perez T. et al. Global stroke bill of rights, Int J Stroke, 2014, 9 (8), 964.

59. Datta, J. and Petticrew, M. Challenges to evaluating complex interventions: a content analysis of published papers. BMC Public Health.2013, 13, 568. 
60. De Wit L., Putman K., Lincoln N., Baert I., Berman P., Beyens H. et al. Stroke rehabilitation in Europe: what do physiotherapists and occupational therapists actually do? Stroke. 2006, 37 (6), 1483-9.

61. De Wit L., Putman K., Schuback B., Komarek A., Angst F., Baert I., et al. Motor and functional recovery after stroke: a comparison of 4 European rehabilitation centers. Stroke. 2007, 38 (7), 2101-7.

62. Duncan P.W., Wallace D., Studenski S., Lai S.M., Johnson D. Conceptualization of a new stroke-specific outcome measure: the stroke impact scale. Top Stroke Rehabil. 2001, 8 (2), 1933.

63. Eriksson M., Glader E.L., Norrving B., Terent A., Stegmayr B. Sex differences in stroke care and outcome in the Swedish national quality register for stroke care. Stroke. 2009, 40 (3), 90914.

64. European Stroke Organization. Guidelines for management of ischaemic stroke and transient ischaemic attack 2008. Cerebrovasc Dis. 2008, 25 (5), 457-507.

65. Ewert T., Grill E., Bartholomeyczik S., Finger M., Mokrusch T., Kostanjsek N. et al. ICF Core Set for patients with neurological conditions in the acute hospital. Disabil Rehabil. 2005, 27 (78), 367-73.

66. Fayed, N., Cieza, A., and Bickenbach, J. E. Linking health and health-related information to the ICF: a systematic review of the literature from 2001 to 2008. Disabil Rehabil. 2011, 33 (21-22), 1941-51.

67. Feigin V.L., Barker-Collo S., Parag V., Senior H., Lawes C.M., Ratnasabapathy Y. et al.Auckland Stroke Outcomes Study. Part 1: Gender, stroke types, ethnicity, and functional outcomes 5 years poststroke. Neurology. 2010, 75 (18), 1597-607.

68. Feigin V.L., Forouzanfar M.H., Krishnamurthi R., Mensah G.A., Connor M., Bennett D.A. et al. Global and regional burden of stroke during 1990-2010: findings from the Global Burden of Disease Study 2010. Lancet. 2014, 383 (9913), 245-54.

69. Folstein, M. F., Folstein, S. E., and McHugh, P. R. "Mini-mental state". A practical method for grading the cognitive state of patients for the clinician. J Psychiatr Res. 1975, 12 (3), 189-98.

70. Garofolo K.M., Yeatts S.D., Ramakrishnan V., Jauch E.C., Johnston K.C., Durkalski V.L. The effect of covariate adjustment for baseline severity in acute stroke clinical trials with responder analysis outcomes, 2013. Trials. 14, 98.

71. Geyh S., Peter C., Muller R. et al. The Personal factors of Inernational Classification of Functioning, Disability and Health in the literature - a systematic review and content analysis. Disability and Rehabilitation. 2011, 33 (13-14), 1089-102.

72. Geyh S., Cieza A., Schouten J., Dickson H., Frommelt P., Omar Z. et al. ICF Core Sets for stroke. J Rehabil Med. 2004, (44 Suppl), 135-41.

73. Ghatnekar O., Persson U., Asplund K., Glader E.L. Costs for stroke in Sweden 2009 and developments since 1997. Int J Technol Assess Health Care. 2014, 30 (2), 203-9.

74. Glassel A., Coenen M., Kollerits B., Cieza A. Validation of the extended ICF core set for stroke from the patient perspective using focus groups. Disabil Rehabil. 2012, 34 (2), 157-66.

75. Glassel A., Coenen M., Kollerits B., Cieza A. Content validation of the International Classification of Functioning, Disability and Health Core Set for stroke from gender perspective using a qualitative approach. Eur J Phys Rehabil Med. 2014, 50 (3), 285-99.

76. Goljar N., Burger H., Vidmar G., Leonardi M., Marincek C. Measuring patterns of disability using the International Classification of Functioning, Disability and Health in the post-acute stroke rehabilitation setting. J Rehabil Med. 2011, 43 (7), 590-601.

77. Grant, C., Goldsmith, C. H., and Anton, H. A. Inpatient stroke rehabilitation lengths of stay in Canada derived from the National Rehabilitation Reporting System, 2008 and 2009. Arch Phys Med Rehabil. 2014, 95 (1), 74-8.

78. Grill E., Lipp B., Boldt C., Stucki G., Koenig E. Identification of relevant ICF categories by patients with neurological conditions in early post-acute rehabilitation facilities. Disabil Rehabil. 2005, 27 (7-8), 459-65.

79. Grimby G., Gudjonsson G., Rodhe M., Sunnerhagen K.S., Sundh V., Ostensson M.L. The functional independence measure in Sweden: experience for outcome measurement in rehabilitation medicine. Scand J Rehabil Med. 1996, 28 (2), 51-62.

80. Grimby, G., Tennant, A., and Tesio, L. The use of raw scores from ordinal scales: time to end malpractice?. J Rehabil Med. 2012, 44 (2), 97-8. 
81. Gustavsson A., Svensson M., Jacobi F., Allgulander C., Alonso J., Beghi E. et al. Cost of disorders of the brain in Europe 2010. Eur Neuropsychopharmacol. 2011, 21 (10), 718-79.

82. Gutenbrunner C., Neumann V., Lemoine F., Delarque A. Describing and developing the field of competence in Physical and Rehabilitation Medicine (PRM) in Europe - preface to a series of papers published by the Professional Practice Committee of the PRM section of the Union of European Medical Specialists (UEMS). Ann Phys Rehabil Med. 2010, 53 (10), 593-7.

83. Gutenbrunner C., Negrini S., Kiekens C., Zampolini M., Nugraha B. The Global Disability Action Plan 2014-2021 of the World Health Organisation (WHO): a major step towards better health for all people with disabilities. Chance and challenge for Physical and Rehabilitation Medicine (PRM). Eur J Phys Rehabil Med. 2015, 51 (1), 1-4.

84. Hacke W., Donnan G., Fieschi C., Kaste M., von Kummer R., Broderick JP. et al. Association of outcome with early stroke treatment: pooled analysis of ATLANTIS, ECASS, and NINDS rtPA stroke trials. Lancet. 2004, 363 (9411), 768-74.

85. Haigh R., Tennant A., Biering-Sorensen F., Grimby G., Marincek C., Phillips S. et al. The use of outcome measures in physical medicine and rehabilitation within Europe. J Rehabil Med. 2001, 33 (6), 273-8.

86. Hakkennes, S. J., Brock, K., and Hill, K. D. Selection for inpatient rehabilitation after acute stroke: a systematic review of the literature. Arch Phys Med Rehabil. 2011, 92 (12), 2057-70.

87. Hanga, K., DiNitto, D., and Leppik, L. Initial assessment of rehabilitation needs using the WHODAS 2.0 in Estonia. Disabil Rehabil. 2016, 38(3), 260-7.

88. Hobart, J. and Cano, S. Improving the evaluation of therapeutic interventions in multiple sclerosis: the role of new psychometric methods. Health Technol Assess. 2009, 13 (12), iii, ix-x, $1-177$.

89. Horn S.D., DeJong G., Ryser D.K., Veazie P.J., Teraoka J. Another look at observational studies in rehabilitation research: going beyond the holy grail of the randomized controlled trial. Arch Phys Med Rehabil. 2005, 86 (12 Suppl 2), S8-S15.

90. Jahiel, R. I. and Scherer, M. J. Initial steps towards a theory and praxis of person-environment interaction in disability. Disabil Rehabil. 2010, 32 (17), 1467-74.

91. Jette A.M., Tao W., Norweg A., Haley S. Interpreting rehabilitation outcome measurements. $J$ Rehabil Med. 2007, 39 (8), 585-90.

92. Kankeu H.T., Saksena P., Xu K., Evans D.B. The financial burden from non-communicable diseases in low- and middle-income countries: a literature review. Health Res Policy Syst. 2013, 11,31 .

93. Kasmel A., Helasoja V., Lipand A., Prattala R., Klumbiene J., Pudule I. Association between health behaviour and self-reported health in Estonia, Finland, Latvia and Lithuania. Eur J Public Health. 2004,14 (1), 32-6.

94. Kelly-Hayes M., Beiser A., Kase C.S., Scaramucci A., D'Agostino R.B., Wolf P.A. The influence of gender and age on disability following ischemic stroke: the Framingham study. $J$ Stroke Cerebrovasc Dis. 2003, 12 (3), 119-26.

95. Knoflach M., Matosevic B., Rucker M., Furtner M., Mair A., Wille G. et al. Functional recovery after ischemic stroke--a matter of age: data from the Austrian Stroke Unit Registry. Neurology. 2012, 78 (4), 279-85.

96. Koh G.C., Chen C., Cheong A., Choo T.B., Pui C.K., Phoon F.N. et al. Trade-offs between effectiveness and efficiency in stroke rehabilitation. Int J Stroke. 2012,7 (8), 606-14.

97. Kucukdeveci A.A., Tennant A., Grimby G., Franchignoni F. Strategies for assessment and outcome measurement in physical and rehabilitation medicine: an educational review. J Rehabil Med. 2011, 43 (8), 661-72.

98. Kucukdeveci A.A., Kutlay S., Yildizlar D., Oztuna D., Elhan A.H., Tennant A.The reliability and validity of the World Health Organization Disability Assessment Schedule (WHODAS-II) in stroke. Disabil Rehabil. 2013, 35 (3), 214-20.

99. Kwakkel, G., Kollen, B., and Lindeman, E. Understanding the pattern of functional recovery after stroke: facts and theories. Restor Neurol Neurosci. 22 (3-5), 281-99.

100. Langhorne, P., de Villiers, L., and Pandian, J. D. Applicability of stroke-unit care to low-income and middle-income countries. Lancet Neurol. 2012, 11 (4), 341-8.

101. Lees K.R., Bath P.M., Schellinger P.D., Kerr D.M., Fulton R., Hacke W, et al. Contemporary outcome measures in acute stroke research: choice of primary outcome measure. Stroke. 2012, 43 (4), 1163-70. 
102. Leira E.C., Hess D.C., Torner J.C., Adams H.P., Jr. Rural-urban differences in acute stroke management practices: a modifiable disparity. Arch Neurol. 2008, 65 (7), 887-91.

103. Lemberg I., Kirchberger I., Stucki G., Cieza A. The ICF Core Set for stroke from the perspective of physicians: a worldwide validation study using the Delphi technique. Eur J Phys Rehabil Med. 2010, 46 (3), 377-88.

104. Leonardi M., Bickenbach J., Ustun T.B., Kostanjsek N., Chatterji S. The definition of disability: what is in a name? Lancet. 2006, 368 (9543), 1219-21.

105. Lindsay P., Furie K.L., Davis S.M., Donnan G.A., Norrving B. World stroke organization global stroke services guidelines and action plan. Int J Stroke. 2014, 9 Suppl A100, 4-13.

106. Lisabeth L.D., Sanchez B.N., Baek J., Skolarus L.E., Smith M.A., Garcia N. et al. Neurological, functional, and cognitive stroke outcomes in Mexican Americans. Stroke. 2014, 45 (4), 1096101.

107. Lopez A.D., Mathers C.D., Ezzati M., Jamison D.T, Murray C.J. Global and regional burden of disease and risk factors, 2001: systematic analysis of population health data. Lancet. 2006, 367 (9524), 1747-57.

108. Lundgren Nilsson, A. and Tennant, A. Past and present issues in Rasch analysis: the functional independence measure (FIM) revisited. J Rehabil Med. 2011, 43 (10), 884-91.

109. Mahoney, F. I. and Barthel, D. W. Functional Evaluation: The Barthel Index. Md State Med J. $1965,14,61-5$.

110. Mayo N.E., Bronstein D., Scott S.C., Finch L.E., Miller S. Necessary and sufficient causes of participation post-stroke: practical and philosophical perspectives. Qual Life Res. 2014, 23 (1), $39-47$.

111. Mayo N.E., Anderson S., Barclay R., Cameron J.I., Desrosiers J., Eng J.J., et al. Getting on with the rest of your life following stroke: A randomized trial of a complex intervention aimed at enhancing life participation post stroke. Clin Rehabil. 2015, 29(12), 1198-211.

112. McKevitt, C., Luse, A., and Wolfe, C. The unfortunate generation: stroke survivors in Riga, Latvia. Soc Sci Med. 2003, 56 (10), 2097-108.

113. Meyer M.J., Pereira S., McClure A., Teasell R., Thind A., Koval J. et al. A systematic review of studies reporting multivariable models to predict functional outcomes after post-stroke inpatient rehabilitation. Disabil Rehabil. 2015; 37(15), 1316-23.

114. Meyer S., Verheyden G., Brinkmann N., Dejaeger E., De Weerdt W., Feys H. et al. Functional and motor outcome 5 years after stroke is equivalent to outcome at 2 months: follow-up of the collaborative evaluation of rehabilitation in stroke across europe. Stroke. 2015, 46 (6), 1613-9.

115. Mukherjee, D. and Patil, C. G. Epidemiology and the global burden of stroke. World Neurosurg. 2011, 76 (6 Suppl), S85-90.

116. Nguyen V.Q., PrvuBettger J., Guerrier T., Hirsch M.A., Thomas J.G., Pugh T.M. et al. Factors associated with discharge to home versus discharge to institutional care after inpatient stroke rehabilitation. Arch Phys Med Rehabil. 2015, 96 (7), 1297-303.

117. Nichols M, Townsend N, Scarborough P, Rayner M. Cardiovascular disease in Europe 2014: epidemiological update. Eur Heart J. 2014, 35 (42), 2950-9.

118. Nichols M., Townsend N., Scarborough P., Rayner M. Cardiovascular disease in Europe: epidemiological update. Eur Heart J. 2013, 34 (39), 3028-34.

119. Nilsson, A. L., Sunnerhagen, K. S., and Grimby, G. Scoring alternatives for FIM in neurological disorders applying Rasch analysis. Acta Neurol Scand. 2005, 111 (4), 264-73.

120. O'Donnell M.J., Xavier D., Liu L., Zhang H., Chin S.L., Rao-Melacini P., et al. Risk factors for ischaemic and intracerebral haemorrhagic stroke in 22 countries (the INTERSTROKE study): a case-control study. Lancet. 2010, 376 (9735), 112-23.

121. Optimising Analysis of Stroke Trials C., Bath P.M., Gray L.J., Collier T., Pocock S., Carpenter J. Can we improve the statistical analysis of stroke trials? Statistical reanalysis of functional outcomes in stroke trials. Stroke. 2007, 38 (6), 1911-5.

122. Ottenbacher K.J., Hsu Y., Granger C.V., Fiedler R.C. The reliability of the functional independence measure: a quantitative review. Arch Phys Med Rehabil. 1996, 77 (12), 1226-32.

123. Ovbiagele B., Goldstein L.B., Higashida R.T., Howard V.J., Johnston S.C., Khavjou O.A. et al. Forecasting the future of stroke in the United States: a policy statement from the American Heart Association and American Stroke Association. Stroke. 2013, 44 (8), 2361-75.

124. Owolabi, M. O. Impact of stroke on health-related quality of life in diverse cultures: the BerlinIbadan multicenter international study. Health Qual Life Outcomes. 2011, 9, 81. 
125. Pack, T. G., Szirony G.M., Kushner J.D., Bellaw J.R. Quality of life and employment in persons with multiple sclerosis. Work. 2014, 49 (2), 281-7.

126. Peoples, H., Satink, T., and Steultjens, E. Stroke survivors experiences of rehabilitation: a systematic review of qualitative studies. Scand J Occup Ther. 2011, 18 (3), 163-71.

127. Pereira S., Foley N., Salter K., McClure J.A, Meyer M., Brown J. et al. Discharge destination of individuals with severe stroke undergoing rehabilitation: a predictive model. Disabil Rehabil. 2014, 36 (9), 727-31.

128. Persson, J., Ferraz-Nunes, J., and Karlberg, I. Economic burden of stroke in a large county in Sweden. BMC Health Serv Res, 2012, 12, 341.

129. Phipps M.S., Jia H., Chumbler N.R., Li X., Castro J.G., Myers J., et al.. Rural-urban differences in inpatient quality of care in US Veterans with ischemic stroke. J Rural Health. 2014, 30 (1), $1-6$.

130. PRM Section of UEMS. White book on physical and rehabilitation medicine in Europe. Eura Medicophys. 2006, 42 (4), 292-332.

131. Putman, K. and De Wit, L. European comparison of stroke rehabilitation. Top Stroke Rehabil. 16 (1), 2009, 20-6.

132. Putman K., de Wit L., Schupp W., Ilse B., Berman P., Connell L. et al. Use of time by physiotherapists and occupational therapists in a stroke rehabilitation unit: a comparison between four European rehabilitation centres. Disabil Rehabil. 2006, 28 (22), 1417-24.

133. Quinn T.J., Dawson J., Walters M.R., Lees K.R. Functional outcome measures in contemporary stroke trials. Int J Stroke. 2009a, 4 (3), 200-5.

134. Quinn T.J., Paolucci S., Sunnerhagen K.S., Sivenius J., Walker M.F., Toni D. et al. Evidencebased stroke r-ehabilitation: an expanded guidance document from the european stroke organisation (ESO) guidelines for management of ischaemic stroke and transient ischaemic attack 2008. J Rehabil Med. 2009b, 41 (2), 99-111.

135. Quintas R., Cerniauskaite M., Ajovalasit D., Sattin D., Boncoraglio G., Parati E.A. et al. Describing functioning, disability, and health with the International Classification of Functioning, Disability, and Health Brief Core Set for Stroke. Am J Phys Med Rehabil. 2012, 91 (13 Suppl 1), S14-21.

136. Rentsch H.P., Bucher P., Dommen Nyffeler I., Wolf C., Hefti H., Fluri E., et al. The implementation of the International Classification of Functioning, Disability and Health (ICF) in daily practice of neurorehabilitation: an interdisciplinary project at the Kantonsspital of Lucerne, Switzerland. Disabil Rehabil. 2003, 25 (8), 411-21.

137. Rhoda A., Smith M., Putman K., Mpofu R., DeWeerdt W., DeWit L. Motor and functional recovery after stroke: a comparison between rehabilitation settings in a developed versus a developing country. BMC Health Serv Res. 2014, 14, 82.

138. Robinson C.A., Shumway-Cook A., Ciol M.A., Kartin D. Participation in community walking following stroke: subjective versus objective measures and the impact of personal factors. Phys Ther. 2011, 91 (12), 1865-76.

139. Rochette, A., Desrosiers, J., and Noreau, L. Association between personal and environmental factors and the occurrence of handicap situations following a stroke. Disabil Rehabil. 2001, 23 (13), 559-69.

140. Roding J., Glader E.L., Malm J., Eriksson M., Lindstrom B. Perceived impaired physical and cognitive functions after stroke in men and women between 18 and 55 years of age--a national survey. Disabil Rehabil. 2009, 31 (13), 1092-9.

141. Roding J., Glader E.L., Malm J., Lindstrom B. Life satisfaction in younger individuals after stroke: different predisposing factors among men and women. J Rehabil Med. 2010, 2 (2), 15561.

142. Rodriguez D., Cox M., Zimmer L.O., Olson D.M., Goldstein L.B., Drew L. et al. Similar secondary stroke prevention and medication persistence rates among rural and urban patients. $J$ Rural Health. 2011, 27 (4), 401-8.

143. Roozenbeek B., Lingsma H.F., Perel P., Edwards P., Roberts I., Murray G.D. et al. The added value of ordinal analysis in clinical trials: an example in traumatic brain injury. Crit Care. 2011, 15 (3), R127.

144. Salter K. Jutai J.W., Teasell R., Foley N.C., Bitensky J. Issues for selection of outcome measures in stroke rehabilitation: ICF Body Functions. Disabil Rehabil. 2005 a, 27 (4), 191-207. 
145. Salter K. Jutai J.W., Teasell R., Foley N.C., Bitensky J., Bayley M. Issues for selection of outcome measures in stroke rehabilitation: ICF activity. Disabil Rehabil. 2005b, 27 (6), 315-40.

146. Salter K. Jutai J.W., Teasell R., Foley N.C., Bitensky J., Bayley M. Issues for selection of outcome measures in stroke rehabilitation: ICF Participation. Disabil Rehabil. 2005c, 27 (9), 507-28.

147. Salvador-Carulla, L. and Garcia-Gutierrez, C. The WHO construct of health-related functioning (HrF) and its implications for health policy. BMC Public Health. 2011, 11 Suppl 4, S9.

148. Saver, J. L. Novel end point analytic techniques and interpreting shifts across the entire range of outcome scales in acute stroke trials. Stroke. 2007, 38 (11), 3055-62.

149. Schepers V.P., Ketelaar M., van de Port I.G., Visser-Meily J.M., Lindeman E. Comparing contents of functional outcome measures in stroke rehabilitation using the International Classification of Functioning, Disability and Health. Disabil Rehabil. 2007, 29 (3), 221-30.

150. Segal, M. E. and Whyte, J. Modeling case mix adjustment of stroke rehabilitation outcomes. Am J Phys Med Rehabil. 1997, 76 (2), 154-61.

151. Seshadri S., Beiser A., Kelly-Hayes M., Kase C.S., Au R., Kannel W.B. et al. The lifetime risk of stroke: estimates from the Framingham Study. Stroke. 2006, 37 (2), 345-50.

152. Shrier, I. and Platt, R. W. Reducing bias through directed acyclic graphs. BMC Med Res Methodol. 2008, 8, 70.

153. Skolarus L.E., Burke J.F., Brown D.L., Freedman V.A. Understanding stroke survivorship: expanding the concept of poststroke disability. Stroke. 2014, 45 (1), 224-30.

154. Snogren, M. and Sunnerhagen, K.S. Description of functional disability among younger stroke patients: exploration of activity and participation and environmental factors. Int $J$ Rehabil Res. 2009, 32 (2), 124-31.

155. Stallinga H.A., Dijkstra P.U., Bos I., Heerkens Y.F., Roodbol P.F. The ambiguity of the concept of participation in measurement instruments: operationalization of participation influences research outcomes. Clin Rehabil. 2014, 28 (12), 1225-36.

156. Steiner T., Kaste M., Forsting M., Mendelow D., Kwiecinski H., Szikora I. et al. Recommendations for the management of intracranial haemorrhage - part I: spontaneous intracerebral haemorrhage. The European Stroke Initiative Writing Committee and the Writing Committee for the EUSI Executive Committee. Cerebrovasc Dis. 2006, 22 (4), 294-316.

157. Strong, K., Mathers, C., and Bonita, R. Preventing stroke: saving lives around the world. Lancet Neurol. 2007, 6 (2), 182-7.

158. Stummer C., Verheyden G., Putman K., Jenni W., Schupp W., De Wit L. Predicting sickness impact profile at six months after stroke: further results from the European multi-center CERISE study. Disabil Rehabil. 2015, 37 (11), 942-50.

159. Sunnerhagen, K. S. (2014), Reflecting the World Report on Disability: a report from Sweden. Am J Phys Med Rehabil. 2014, 93 (1 Suppl 1), S42-6.

160. Sunnerhagen K.S., Flansbjer U.B., Lannsjo M., Tolli A., Lundgren-Nilsson A. WebRehab: A Swedish database for quality control in rehabilitation. J Rehabil Med. 2014, 46 (10), 958-62.

161. Takac P., Petrovicova J., Delarque A., Stibrant Sunnerhagen K., Neumann V., Vetra A. et al. Position paper on PRM and persons with long term disabilities. Eur J Phys Rehabil Med. 2014, $50(4), 453-64$.

162. Tarvonen-Schroder S., Laimi K., Kauko T., Saltychev M. Concepts of capacity and performance in assessment of functioning amongst stroke survivors: A comparison of the Functional Independence Measure and the International Classification of Functioning, Disability and Health. J Rehabil Med. 2015, 47 (7), 662-4.

163. Teale E.A., Forster A., Munyombwe T., Young J.B. A systematic review of case-mix adjustment models for stroke. Clin Rehabil. 2012, 26 (9), 771-86.

164. Teasdale, G. and Jennett, B. Assessment of coma and impaired consciousness. A practical scale. Lancet. 1974, 2 (7872), 81-4.

165. Textor, J., Hardt, J., and Knuppel, S. DAGitty: a graphical tool for analyzing causal diagrams. Epidemiology. 2011, 22 (5), 745.

166. Thoren-Jonsson, A. L. Coming to terms with the shift in ones capabilities: a study of the adaptive process in persons with poliomyelitis sequelae. Disabil Rehabil. 2001, 23 (8), 341-51.

167. Ustun T.B., Chatterji S., Kostanjsek N., Rehm J., Kennedy C., Epping-Jordan J. et al. Developing the World Health Organization Disability Assessment Schedule 2.0. Bull World Health Organ. 2010, 88 (11), 815-23. 
168. van Swieten J.C., Koudstaal P.J., Visser M.C., Schouten H.J., van Gijn J. Interobserver agreement for the assessment of handicap in stroke patients. Stroke. 1988, 19 (5), 604-7.

169. Verheyden G., Nieuwboer A., De Wit L., Thijs V., Dobbelaere J., Devos H., et al. Time course of trunk, arm, leg, and functional recovery after ischemic stroke. Neurorehabil Neural Repair. 2008, 22 (2), 173-9.

170. Vincent C., Desrosiers J., Landreville P., Demers L. Burden of caregivers of people with stroke: evolution and predictors. Cerebrovasc Dis. 2009, 27 (5), 456-64.

171. Vos T., Flaxman A.D., Naghavi M., Lozano R., Michaud C., Ezzati M. et al. Years lived with disability (YLDs) for 1160 sequelae of 289 diseases and injuries 1990-2010: a systematic analysis for the Global Burden of Disease Study 2010. Lancet. 2012, 380 (9859), 2163-96.

172. Walsh M.E., Galvin R., Loughnane C., Macey C., Horgan N.F. Community re-integration and long-term need in the first five years after stroke: results from a national survey. Disabil Rehabil. 2014, 1-5.

173. Ward A.B., Gutenbrunner C., Damjan H., Giustini A., Delarque A. European Union of Medical Specialists (UEMS) section of Physical \& Rehabilitation Medicine: a position paper on physical and rehabilitation medicine in acute settings. J Rehabil Med. 2010, 42 (5), 417-24.

174. Ward A., Gutenbrunner C., Giustini A., Delarque A., Fialka-Moser V., Kiekens C. et al. A position paper on Physical \& Rehabilitation Medicine programmes in post-acute settings. Union of European Medical Specialists Section of Physical \& Rehabilitation Medicine (in conjunction with the European Society of Physical \& Rehabilitation Medicine). J Rehabil Med. 2012, 44 (4), 289-98.

175. Ware, J. E., Jr. and Sherbourne, C. D. The MOS 36-item short-form health survey (SF-36). I. Conceptual framework and item selection. Med Care. 1992, 30 (6), 473-83.

176. Weir N.U., Sandercock P.A., Lewis S.C., Signorini D.F., Warlow C.P. Variations between countries in outcome after stroke in the International Stroke Trial (IST). Stroke. 2001, 32 (6), $1370-7$.

177. White J.H., Alston M.K., Marquez J.L., Sweetapple A.L., Pollack M.R., Attia J. et al. Community-dwelling stroke survivors: function is not the whole story with quality of life. Arch Phys Med Rehabil. 2007, 88 (9), 1140-6.

178. WHO Task Force on Stroke and Other Cerebrovascular Disorders. Stroke--1989. Recommendations on stroke prevention, diagnosis, and therapy. Report of the WHO Task Force on Stroke and other Cerebrovascular Disorders. Stroke.1989, 20 (10), 1407-31.

179. Yusuf S., Rangarajan S., Teo K., Islam S., Li W., Liu L. et al. Cardiovascular risk and events in 17 low-, middle-, and high-income countries. N Engl J Med. 2014, 371 (9), 818-27.

\section{Internet resources:}

180. StrokeEngine. StrokeEngine Assess, <http://strokengine.ca/assess/>, [Last accessed October 17, 2013].

181. WHO Global Infobase. Data for saving lives, https://apps.who.int/infobase/ [Last accessed 8 July, 2015]. 
ATTACHMENTS 


\section{A comparison of stroke rehabilitation; data from two national cohorts}

\author{
Bērziņa G, Vētra A, Sunnerhagen KS. A comparison of stroke \\ rehabilitation; data from two national cohorts. \\ Acta Neurol Scand: DOI: 10.1111/ane.12542. \\ (C) 2015 John Wiley \& Sons A/S. Published by John Wiley \& Sons Ltd. \\ Objectives - Inpatient rehabilitation is a commonly used complex \\ intervention to improve a person's independence after stroke. \\ Evaluation and comparison of the effects of routine clinical practice \\ could provide a contribution towards optimization of stroke care. The \\ aim of this study is to describe results of inpatient rehabilitation as a \\ complex intervention for persons after stroke and explore possible \\ differences between two countries. Methods - Data from 1055 Latvian \\ and 1748 Swedish adult patients after stroke receiving inpatient \\ rehabilitation, during 2011-2013, were used for this retrospective \\ cohort study. Qualitative description of systems, as well as \\ information on basic medical and sociodemographic information, and \\ organizational aspects were reported. Change in the Functional \\ Independence Measure during rehabilitation was investigated. In six \\ domains of the instrument, the shifts for three levels of dependence \\ were analysed using ordinal regression analysis. Results - The \\ components of stroke care seem to be similar in Latvia and Sweden. \\ However, the median time since stroke onset until the start of \\ rehabilitation was 13 weeks in Latvia and 2 weeks in Sweden. The \\ median length of rehabilitation was 12 and 49 days, respectively. \\ The level of dependency at start, time since stroke onset and length of \\ the period had an impact on the results of the rehabilitation. \\ Conclusions - Although components of the rehabilitation are reported \\ as being the same, characteristics and the outcome of the inpatient \\ rehabilitation are different. Therefore, comparison of stroke \\ rehabilitation between countries requires caution.
}

\author{
G. Bērzinga ${ }^{1}$, A. Vētra ${ }^{1}$, \\ K. S. Sunnerhagen ${ }^{2}$ \\ ${ }^{1}$ Riga Stradiņš University, Riga, Latvia; ${ }^{2}$ University of \\ Gothenburg, Gothenburg, Sweden \\ Key words: activities of daily living; stroke; complex \\ interventions; length of stay; rehabilitation; shift \\ analysis \\ G. Bērziņa, Department of Rehabilitation, Riga Stradiņš \\ University, Anniņmuižas Boulevard 26a, Riga LV-1067, \\ Latvia \\ Tel.: +37129436495 \\ e-mail: berzina.guna@gmail.com \\ Accepted for publication November 11, 2015
}

\section{Introduction}

Of the persons who experience stroke, one-third die (1) and approximately half of the survivors live with restrictions in daily life, that is longterm disability (2). Therefore, stroke not only creates an emotional and financial burden for the person who suffers from it and his/her relatives $(3,4)$, but also plays an important role on global burden of diseases, especially in European countries $(5,6)$. Stroke is an ethical and political, local and global issue.

Rehabilitation reduces disability and aims where possible, to improve a person's independence through minimizing negative effects of stroke and/or enabling adaptation strategies (7, 8). Rehabilitation should start as soon as possible after the event and continue as long as needed, though with a different content and intensity, even after discharge (9). The overall success of rehabilitation is determined by the interaction of different rehabilitation techniques that are applied depending on the individual needs of the person affected $(7,8)$. Rehabilitation is a complex intervention and its evaluation is in the interests of clinicians, researchers and policymakers (10). The recommendations for the structure of rehabilitation organization provide the theoretical continuity of the process $(9,11)$. The phase of post-acute rehabilitation serves as transition from early rehabilitation in an acute setting, to community-based follow-up rehabilitation. This in- or outpatient rehabilitation service should be goaloriented and multiprofessional (9). 


\section{Bērzinga et al.}

However, there is no unified selection of patients for specialized inpatient rehabilitation. The existing inclusion criteria have a permissive nature and the availability and effectiveness of services in different countries vary depending on local policy and available resources (12-14).

Besides multiprofessional rehabilitation services, inpatient rehabilitation provides also medical and nursing care, available for $24 \mathrm{~h}$ a day. This intervention should be available for those who cannot safely return to their own homes after the event of stroke. Therefore, the main objective of inpatient rehabilitation and, simultaneously, the main outcome of interest is the person's independence in activities of daily living (14).

The CERISE study demonstrated diverse results when comparing four European rehabilitation centres with direct transfer from the acute setting (13). Even so, they state that comparison between countries could serve to guide optimization of stroke care (13).

Sweden has been among the pioneers in the development of specialized stroke care that started during 1970s. In Latvia, these developed approaches were adapted approximately 25 years later, and studies are lacking. The aim of this study is to describe results of inpatient rehabilitation, as a complex intervention, in terms of level of dependence for persons after stroke and explore possible differences between the two national cohorts.

\section{Materials and methods}

Participants

The study has a retrospective design. All patients who received rehabilitation after stroke in the Department of Neurorehabilitation in National Rehabilitation Centre 'Vaivari' form 1 January 2011 to 31 December 2013, were identified through the computerized hospital register. Prespecified data were gathered from the charts and entered into a file. This is the only rehabilitation centre in Latvia that provides publicly funded inpatient rehabilitation in the post-acute phase of stroke. The data from the Swedish population were obtained from the Swedish rehabilitation quality register 'WebRehab Sweden' for the same period of time. This registry has a $>95 \%$ coverage of inpatient rehabilitation units in Sweden.

The study conforms with the ethical principles of Declaration of Helsinki and is approved by the Ethics Committee of Riga Stradinš University, Latvia (27 September 2012).
Inclusion criteria were a diagnosis of stroke [ICD-10 codes 160-167 (15)], clinically determined by specialists from stroke units according to the World Health Organization (WHO) criteria (16), and confirmed by computer tomography scanning; the patient was over the age of 18 and had started rehabilitation more than 1 week but no later than 1 year post-stroke. Data were excluded if the patient was discharged due to need for re-hospitalization in the acute setting, or if they died.

\section{Procedure and instruments}

To compare the Latvian and the Swedish stroke care, a qualitative description of systems was completed. Basic medical (type of stroke diagnosis and side of lesion in the brain), and sociodemographic information (age and gender), as well as organizational aspects of rehabilitation [time since onset of stroke (weeks) until rehabilitation and length of inpatient rehabilitation (days)], was used to describe both populations. The Functional Independence Measure (FIM) (17, 18), which assess dependency in activities of daily living, was used as an outcome variable in this study. It is used as a routine assessment tool, for functioning levels at the beginning of rehabilitation and at discharge in Latvia and Sweden. The instrument is made up of two scales - the Motor Scale with four domains and the Cognitive Scale that includes two domains. In total, FIM consists of 18 items and each is scored in a 7-point ordinal scale, where levels 7 and 6 are used to describe complete and modified independence respectively, and 1-5 - to illustrate levels of dependence.

Data analysis

Descriptive statistics were used for the age and gender, diagnosis and side of lesion of the brain, time since onset of stroke to the beginning of rehabilitation and length of rehabilitation. Independent samples $t$-test and chi-square test for independence were used to compare the characteristics between two populations. The FIM scores at admittance and discharge were grouped into six domains (19): 'Personal care' (FIM A FIM F); 'Sphincter' (FIM G - FIM H); 'Transfer' (FIM I - FIM K); 'Locomotion' (FIM L - FIM M), 'Communication' (FIM N-FIM O) and 'Social Cognition' items (FIM P - FIM R). Since the data are ordinal, they were trichotomized, based on the extent of the person's need for help to fulfil the activity in the following manner: 
A comparison of stroke rehabilitation between countries

'Total dependence' (1) was defined by any score being 1 or 2; 'Partial dependence' (2) if any score was 3, 4 or 5, without 1 or 2; 'Independent' (3), if all items got a score of 6 or 7. Shifts in proportions of these three levels of functioning were analysed for Latvia and Sweden at admittance and discharge and reported using bar graphs. The Wilcoxon signed rank test was conducted to assess the change of the proportions between admittance to and discharge from rehabilitation and effect sizes were reported. As an outcome for analysis, trichotomized FIM discharge scores for six domains were used. For each of outcome, the common odds ratio and $95 \%$ confidence intervals were reported for the shift in the direction of a better outcome towards either populations. The odds ratio was estimated using ordinal regression analysis. For each outcome, three analyses were conducted: unadjusted analysis (without covariates); adjusted for admittance scores (the score shift of the trichotomized scale for the corresponding domain evaluated at the admittance to rehabilitation); and a 'fully' adjusted analysis. Controlling factors for the last model were chosen based on the unique contribution for each factor when conducting an analysis with age, gender, type of diagnosis, side of lesion in the brain, time since onset, length of rehabilitation and proportions of levels of dependence at admittance for the corresponding domain as covariates. The results with a significance level $<0.01$ were reported. Statistical analyses were performed using IBM SPSS Statistics for Windows, Version 21.0 (IBM Corp., Armonk, NY, USA).

\section{Results}

The description of available information on the rehabilitation systems in Latvia and Sweden is shown in Table 1. Additionally, according to the World Bank reported data from 2013, the gross domestic product in Sweden was 4.2 times higher than in Latvia. Therefore, the cost to patients in Latvia places a higher financial burden on affected families.

Between 1 January 2011 and 31 December 2013, 1138 patients after stroke were treated at NRC 'Vaivari' and 3724 received inpatient rehabilitation in different rehabilitation settings in Sweden. Of those, 1055 and 1748 persons, respectively, were included in the study. The most common cause for exclusion in the Swedish population was due to the organization of stroke unit and rehabilitation unit as one (meaning that date of stroke onset and start of rehab were entered as the same). Descriptive statistics and comparison of characteristics of population and organizational aspects of rehabilitation for both countries is given in Table 2 .

The shift of proportions in 'totally dependent', 'partially dependent' and 'independent' groups between admittance to and discharge from rehabilitation for the Latvian and the Swedish stroke populations is illustrated in Fig. 1. Patients in

Table 1 Description of rehabilitation systems

\begin{tabular}{|c|c|c|}
\hline & Latvia & Sweden \\
\hline Stroke units & Since 1 June 2000 & Since 1990s \\
\hline$\%$ treated at the stroke unit & No exact data available & $91 \%$ \\
\hline Stroke rehabilitation available & 1995 & 1970 s \\
\hline $\begin{array}{l}\text { Initial functional assessment to determine } \\
\text { rehabilitation needs and receive } \\
\text { an individualized rehabilitation plan }\end{array}$ & $100 \%$ in stroke units & $100 \%$ in stroke units \\
\hline $\begin{array}{l}\text { Post-acute rehabilitation: All patients who } \\
\text { are admitted to inpatient rehabilitation } \\
\text { following stroke are treated in a } \\
\text { specialized stroke rehabilitation unit }\end{array}$ & No & No \\
\hline Multiprofessional team & Yes & Yes \\
\hline Funding & Public & Public \\
\hline Patient borne costs & $\begin{array}{l}\text { Yes } \\
\text { 13.50 Euro, except persons with severe } \\
\text { disability, low-income and other social groups }\end{array}$ & $\begin{array}{l}\text { Yes } \\
\text { Depend on the county, } \\
\text { but not more than } 10 \text { Euro }\end{array}$ \\
\hline Follow-up & Some & Yes \\
\hline Other options for rehabilitation & $\begin{array}{l}\text { Home based rehabilitation } \\
\text { Day rehabilitation units } \\
\text { Out-patient rehabilitation }\end{array}$ & $\begin{array}{l}\text { Home based rehabilitation } \\
\text { Day rehabilitation units } \\
\text { Out-patient rehabilitation }\end{array}$ \\
\hline Quality registers & No & $\begin{array}{l}\text { 'Riks-Stroke', the Swedish } \\
\text { stroke register since } 1994 \\
\text { 'WebRehab' since } 1997\end{array}$ \\
\hline
\end{tabular}




\section{Bērzinga et al.}

Table 2 Baseline characteristics of patients

\begin{tabular}{|c|c|c|c|}
\hline & Latvia $(N=1055)$ & Sweden $(N=1748)$ & Comparison \\
\hline \multicolumn{4}{|l|}{ Age (years) } \\
\hline Mean (SD) & $64.7(11.9)$ & $58.0(12.8)$ & \multirow{2}{*}{$t(2801.982)=13.76, \eta^{2}=0.06^{*}$} \\
\hline Median (IQR) & $66(57-74)$ & $59(51-64)$ & \\
\hline Male $(\%)$ & $556(52.7)$ & $1059(60.6)$ & $\chi^{2}(1, n=2803)=16.42 ; \varphi=-0.077^{\dagger}$ \\
\hline \multicolumn{4}{|l|}{ ICD-10 diagnosis (\%) } \\
\hline 160 & $20(1.9)$ & $252(14.4)$ & \multirow[t]{6}{*}{$\chi^{2}(5, n=2799)=315.56 ;$ Cramer's $V=0.336^{\dagger}$} \\
\hline 161 & $135(12.8)$ & $423(24.2)$ & \\
\hline 162 & $5(0.5)$ & $42(2.4)$ & \\
\hline 163 & $871(82.9)$ & $920(52.6)$ & \\
\hline 164 & $16(1.5)$ & $9(0.5)$ & \\
\hline Other/unknown & $8(0.8)$ & $102(5.8)$ & \\
\hline \multicolumn{4}{|l|}{ Side of lesion (\%) } \\
\hline Right hemisphere & $368(34.9)$ & $444(25.4)$ & \multirow[t]{5}{*}{$\chi^{2}(4, n=2379)=155.53 ;$ Cramer's $V=0.256^{\dagger}$} \\
\hline Left hemisphere & $408(38.7)$ & $494(28.3)$ & \\
\hline Vertebrobasilar system & $175(16.6)$ & $144(8.2)$ & \\
\hline Different locations & $39(3.7)$ & $150(8.6)$ & \\
\hline Other/unknown & $65(6.2)$ & $516(29.5)$ & \\
\hline \multicolumn{4}{|c|}{ Time since onset of stroke (weeks) } \\
\hline Mean (SD) & $13.8(6.3)$ & $4.0(6.3)$ & \multirow[t]{2}{*}{$t(1970.64)=36.12 ; \eta^{2}=0.32^{*}$} \\
\hline Median (IQR) & 13 (9-18) & $2(1-4)$ & \\
\hline \multicolumn{4}{|c|}{ Length of rehabilitation (days) } \\
\hline Mean (SD) & $14.6(7.1)$ & $57.8(37.6)$ & \multirow[t]{2}{*}{$t(1945.53)=46.74, \eta^{2}=0.44^{*}$} \\
\hline Median (IQR) & 12 (9-18) & $48.50(31-76)$ & \\
\hline
\end{tabular}

SD, standard deviation; IQR, interquartile range.

*Independent samples $t$-test.

${ }^{\dagger}$ Chi-square test for independence.

Sweden were admitted to rehabilitation with higher dependency levels than in Latvia, especially in the motor activities of daily living, such as 'self-care' and 'locomotion'. The change in proportions during the course of rehabilitation was more explicit in the Swedish population; however, they were statistically significant for all six FIM domains in both populations.

The ordinal logistic regression analysis of all covariates showed that the dependence level for the corresponding domain at admittance, age, time since onset and length of rehabilitation were the significant contributing factors in almost all domains. In the domain, 'Communication' a contribution of length of stay, while controlling for other factors, was not significant; therefore, it was excluded from the analysis. All estimated odds for a better outcome between populations in the analysis were statistically significant, except the unadjusted odds ratio for 'sphincter' $(P=0.13)$ and the 'fully' adjusted odds ratio for 'communication' $(P=0.67)$. The common odds ratios between both populations for all six domains are reported in Fig. 2. Results show that the odds for a better level of independence at discharge from rehabilitation in 'self-care', 'locomotion', communication' and 'social cognition' were higher for Latvian patients, before the adjustment for significant factors. After adjustment for admittance scores, the odds considerably changed in favour of the Swedish population. The odds of a better outcome for the Swedish population remained the same or somewhat decreased when adjusting for all significant factors.

\section{Discussion}

The results of this study show that although the components of stroke care seem to be similar in Latvia and Sweden, there are potential differences in its content and organizational aspects of rehabilitation. Both populations vary in their basic medical and sociodemographic characteristics, as well as in the level of independence at admittance and discharge.

In Latvia and Sweden, inpatient rehabilitation is organized through a multiprofessional team, with nursing and medical care available $24 \mathrm{~h}$ a day. However, information about the exact content of rehabilitation and its intensity is lacking in both countries. There are no agreed selection criteria for inpatient rehabilitation. So the decision whether to admit a patient or not to the facility is made by rehabilitation specialists in both Latvia and Sweden. These decisions depends also on the organization of the hospital. Approximately 8\% of all stroke survivors are being transferred to specialized rehabilitation in Sweden (20). We 
A comparison of stroke rehabilitation between countries

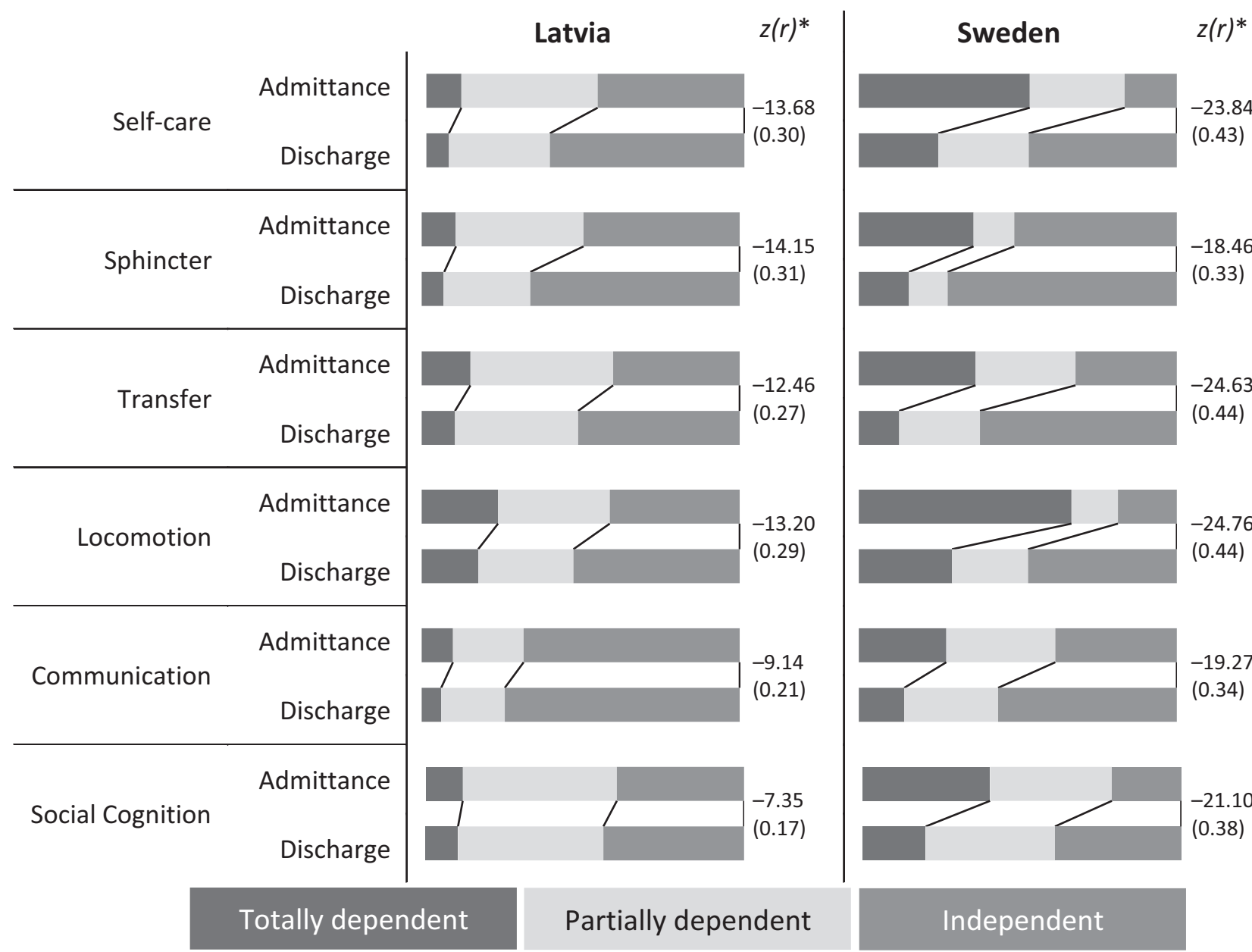

Figure 1. Shift of proportions of levels of dependence between admittance to and discharge from rehabilitation. * Results of Wilcoxon signed rank test between admittance to and discharge from rehabilitation in each population.

estimate that it is twice the number compared to Latvia. In Sweden, guidelines are published for stroke care, which provides more organized patients' selection for rehabilitation settings, whereas, in Latvia, referral to other settings after acute care seems to be more random. The lack of clearly stated mission for specialized inpatient stroke rehabilitation in Latvia could be the reason for less efficient use of resources. This issue has been previously outlined by CERISE project, which showed (in that study) better functional recovery for the patients with more formal management (12).

The funding for inpatient care comes both from the public purse and from contributions from the patients themselves in Latvia as well as in Sweden. However, the patient's cost for rehabilitation at an inpatient facility per day, when you compare this to average wages of each country, is proportionately different between Latvia and Sweden, with higher percentage costs for people in Latvia. Thus, opportunity for those in need of inpatient rehabilitation may be biased by their economical situation. While in Sweden this fee might serve as motivation for participation in the rehabilitation process, in Latvia it could be the reason behind a family's decision to decline this service.

In Latvia, for certain categories (such as status of severe disability or low income), the patient's cost is covered by public resources. This can provide an explanation for possible differences in the incentive for rehabilitation. The CERISE study has previously underlined that selection criteria for rehabilitation are not solely clinical and could depend on organizational and financial aspects (12).

The organization of acute care is important because this is where stroke rehabilitation starts. In Sweden, almost all patients after stroke are treated in stroke units. In Latvia, the information for the percentage of patients treated in a stroke unit is not available. Without clear and precise measurement and assessment of stroke care pathways, persons who likely would benefit from 


\section{Bērzinga et al.}

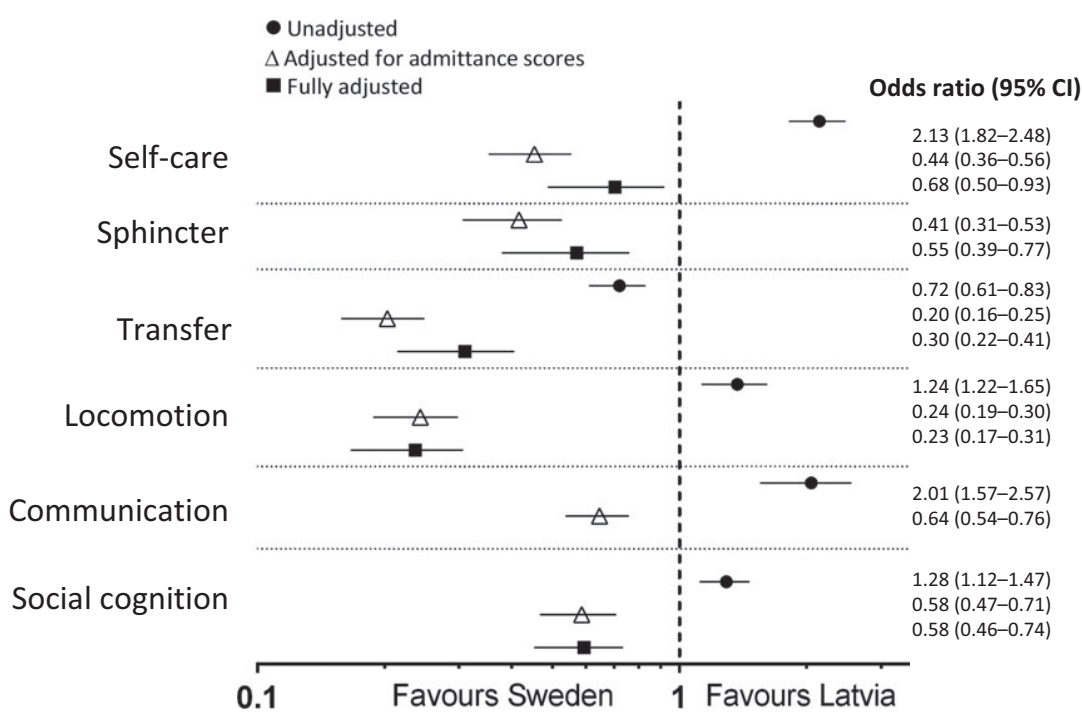

Figure 2. Forest plot for odds in favour of being more independent between Latvia and Sweden.

inpatient rehabilitation may end up excluded from rehabilitation. Systematic and standardized data collection could provide reliable information for comparing different systems, thus avoiding speculations on the quality and efficacy of the services.

The basic sociodemographic and medical, as well as organizational characteristics of rehabilitations are different in both populations. The two most prominent differences between the populations were the length of rehabilitation, and the time between onset of stroke and admittance to rehabilitation.

The contrast between the lengths of rehabilitation in both study populations is large. In the Latvian population, the duration of inpatient rehabilitation is approximately 2 weeks and is relatively fixed, whereas the median length of stay in Sweden, even when compared to other countries, is rather long $(21,22)$. The length of rehabilitation cannot be used as a tool to describe clinical success. According to the accepted standards of rehabilitation, the rehabilitation plan should be individualized and based on the expected improvement, which is not time limited (7). However, time is used as a tool to estimate the costs of the health care process and in some countries can be used to limit the amount of rehabilitation (22).

While most of the patients in Sweden were admitted to rehabilitation within the first month after the event, patients in Latvia usually started after 2-3 months. These figures are in favour of the Swedish system, since the best results can be achieved at earlier phases after stroke onset (8). There are also no data on whether persons after stroke in Latvia received treatment in the period between acute care and being admitted to rehabil- itation. There are several options available: rehabilitation in the home, privately funded rehabilitation at in- or outpatient wards, daycare units or no formal rehabilitation and the pathway is not known. This stresses the importance to be cautious when comparing results of rehabilitation. Therefore, adjusting for confounding factors should be done to make the groups more homogenous (23).

The improvement after rehabilitation towards independence as assessed with FIM was statistically significant in both populations, showing that the interventions had an effect. Usually this has been presented with gain in FIM scores. However, since the FIM data are ordinal it should not be treated as linear (24). We therefore decided to use shift analysis and ordinal regression analysis (25). To our knowledge, this type of analysis has not previously been used in a rehabilitation population with clinical data. The shift between proportions of the levels of dependence from admittance to discharge is more notable in the Swedish population. This was supported by the results of the ordinal regression analysis. Considering the level of independence at admittance to rehabilitation, the patients in Sweden were more likely to improve. Since the Latvian population was more independent at admittance, there is a possibility that improvement during rehabilitation is not detected due to a ceiling effect of the FIM. There were missing data regarding the patients (i.e. stroke subtypes, smoking) and the content of rehabilitation in the data sets, which is a limitation and might have impacted the results.

Our study highlights the importance of multiple aspects of inpatient rehabilitation as a 
complex intervention. The necessity for a complex approach leads to difficulties and restrictions for comparison of the results of the interventions between populations, which is essential for quality assessment in rehabilitation. Having good data gathering in the acute setting, as well as in the rehabilitation setting could make comparisons possible in the future. There is also a need for structured data gathering regarding the content of the complex interventions within stroke rehabilitation, in order to fully evaluate the efficacy.

\section{Conclusions}

Characteristics and the outcome of the inpatient rehabilitation are different in the two countries. Comparing results of rehabilitation between settings most likely is restricted by the lack of information on the content of these complex interventions, although the components of the rehabilitation are reported the same. However, showing improvement in the level of dependence during rehabilitation is easier if the patient is more dependent and receives rehabilitation earlier after stroke onset.

\section{Acknowledgments}

This publication has been produced during GB's scholarship period at the University of Gothenburg, thanks to the Visby Programme of the Swedish Institute. We acknowledge the help from Dr. Rita Seske (Latvia) in data gathering and Drs. Anda Nulle, Inga Tanenberga, Illa Mihejeva and Inese Kokare in interpreting the findings, as well as Asa LundgrenNilsson for help with data analysis. The participating centres in WebRehab contributed with the Swedish data.

\section{Conflict of interest}

The authors declare that they have no financial or nonfinancial competing interests.

\section{References}

1. Feigin VL, Forouzanfar MH, Krishnamurthi R et al. Global and regional burden of stroke during 1990-2010: findings from the Global Burden of Disease Study 2010. Lancet 2014;383:245-54.

2. Mackay J., Mensah G. A. World Health Organization., \& Centers for Disease Control and Prevention (U.S.). The atlas of heart disease and stroke. Geneva: World Health Organization, 2004.

3. Kankeu HT, Saksena P, Xu K, Evans DB. The financial burden from non-communicable diseases in low- and middle-income countries: a literature review. Health Res Policy Syst 2013;11:31.

4. Carod-Artal FJ, Egido JA. Quality of life after stroke: the importance of a good recovery. Cerebrovasc Dis 2009;27(Suppl 1):204-14.
5. Lopez AD, Mathers CD, Ezzati M, Jamison DT, MurRAY CJ. Global and regional burden of disease and risk factors, 2001: systematic analysis of population health data. Lancet 2006;367:1747-57.

6. Vos T, Flaxman AD, Naghavi M et al. Years lived with disability (YLDs) for 1160 sequelae of 289 diseases and injuries 1990-2010: a systematic analysis for the Global Burden of Disease Study 2010. Lancet 2012;380:2163-96.

7. Section of Physical and Rehabilitation Medicine Union Européenne des Médecins Spécialistes (UEMS); European Board of Physical and Rehabilitation Medicine; Académie Européenne de Médecine de Réadaptation; European Society for Physical and Rehabilitation Medicine. White book on physical and rehabilitation medicine in Europe. Eura Medicophys 2006;42:292-332.

8. Quinn TJ, Paolucci S, Sunnerhagen KS et al. Evidencebased stroke rehabilitation: an expanded guidance document from the European Stroke Organisation (ESO) guidelines for management of ischaemic stroke and transient ischaemic attack 2008. J Rehabil Med 2009;41: 99-111.

9. Ward A, Gutenbrunner C, Giustini A et al. A position paper on physical \& rehabilitation medicine programmes in post-acute settings. Union of European Medical Specialists Section of Physical \& Rehabilitation Medicine (in conjunction with the European Society of Physical \& Rehabilitation Medicine). J Rehabil Med 2012;44:289-98.

10. Craig P, Dieppe P, Macintyre $S$ et al. Developing and evaluating complex interventions: the new Medical Research Council guidance. BMJ 2008;337:a1655.

11. Gutenbrunner C, Neumann V, Lemoine F, Delarque A. Describing and developing the field of competence in physical and rehabilitation medicine (PRM) in Europe preface to a series of papers published by the Professional Practice Committee of the PRM section of the Union of European Medical Specialists (UEMS). Ann Phys Rehabil Med 2010;53:593-7.

12. Putman K, De Wit L. European comparison of stroke rehabilitation. Top Stroke Rehabil 2009;16:20-6.

13. De Wit L, Putman K, Schuback B et al. Motor and functional recovery after stroke: a comparison of 4 European rehabilitation centers. Stroke 2007;38:2101-7.

14. Ward AB, Gutenbrunner C, Damuan H, Giustini A Delarque A. European Union of Medical Specialists (UEMS) section of physical \& rehabilitation medicine: a position paper on physical and rehabilitation medicine in acute settings. J Rehabil Med 2010;42:417-24.

15. World Health Organization. International classification of diseases and related health problems: tenth revision. Version for 2010. Geneva: World Health Organization, 2010.

16. Stroke-1989. Recommendations on stroke prevention, diagnosis, and therapy. Report of the WHO Task Force on Stroke and other Cerebrovascular Disorders. Stroke 1989;20:1407-31.

17. Cournan M. Use of the functional independence measure for outcomes measurement in acute inpatient rehabilitation. Rehabil Nurs 2011;36:111-7.

18. Functional independence measurement (FIM) user manual version 1.0. USA: Department of Veterans Affairs, VistA System Design and Development, 2003. Available at: http://www.va.gov/vdl/documents/clinical/func_in dep_meas/fim_user_manual.pdf (accessed 28 November 2015).

19. Grimby G, Gudjonsson G, Rodhe M, Sunnerhagen KS, Sundh V, Ostensson ML. The functional independence measure in Sweden: experience for outcome measurement 


\section{Bērzinga et al.}

in rehabilitation medicine. Scand $\mathbf{J}$ Rehabil Med 1996;28:51-62.

20. Riksstroke. The Swedish Stroke Register. Stroke och TIA. Riksstrokes årsrapport 2014. 2015; http://www.riks stroke.org/sve (accessed 8 September 2015).

21. Grant C, Goldsmith $\mathrm{CH}$, Anton HA. Inpatient stroke rehabilitation lengths of stay in Canada derived from the National Rehabilitation Reporting System, 2008 and 2009. Arch Phys Med Rehabil 2014;95:74-8.

22. Atalay A, Turhan N. Determinants of length of stay in stroke patients: a geriatric rehabilitation unit experience. Int J Rehabil Res 2009;32:48-52.
23. Teale EA, Forster A, Munyombwe T, Young JB. A systematic review of case-mix adjustment models for stroke. Clin Rehabil 2012;26:771-86.

24. Grimby G, Tennant A, Tesio L. The use of raw scores from ordinal scales: time to end malpractice? J Rehabil Med 2012;44:97-8.

25. Bath PM, Lees KR, Schellinger PD et al. Statistical analysis of the primary outcome in acute stroke trials. Stroke 2012;43:1171-8. 


\title{
Living in Latvia after stroke: \\ 2. pielikums the association between functional, social and personal factors and the level of self-perceived disability - a cross-sectional study
}

\author{
Guna Bērzinsa, ${ }^{1}$ Baiba Smilškalne,${ }^{2}$ Anita Vētra, ${ }^{1}$ Katharina Stibrant Sunnerhagen ${ }^{3,4,5}$
}

To cite: Bērzinga $G$, Smilškalne B, Vētra A, et al. Living in Latvia after stroke: the association between functional, social and personal factors and the level of selfperceived disability—a cross-sectional study. BMJ Open 2016;6: 010327. doi:10.1136/bmjopen-2015010327

- Prepublication history for this paper is available online. To view these files please visit the journal online (http://dx.doi.org/10.1136/ bmjopen-2015-010327).

Received 22 October 2015 Revised 12 April 2016 Accepted 28 April 2016

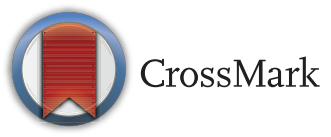

For numbered affiliations see end of article.

Correspondence to

Dr Guna Bērzina;

berzina.guna@gmail.com

\section{ABSTRACT}

Objective: To investigate how functional, social and personal factors are associated with self-perceived level of disability in the chronic phase of stroke in a Latvian stroke population. The consequences of stroke can vary greatly and often leads to long-term disability that, according to the WHO definitions, depends on the interaction between the person and his/her context. Design: Cross-sectional study with retrospective data gathering.

Setting: Community-dwelling persons who received specialised in-patient rehabilitation after stroke in Latvia.

Participants: of 600 persons after stroke who were identified through hospital register and selected for the study, 255 were included in the analysis.

Primary and secondary outcome measures: The medical information and discharge data of the Functional Independence Measure (FIM) was extracted from medical records. Participants filled out a questionnaire on sociodemographic information and the WHO Disability Assessment Schedule 2.0 (WHODAS 2.0), either in Latvian or Russian, depending on their wish when contacted for their oral agreement to participate. Stepwise multiple regression analysis was conducted to find a model that best explains the variance in WHODAS 2.0 scores.

Results: The models explained $23-43.5 \%$ of variance in outcomes. The best explained WHODAS 2.0 domains were 'mobility' and 'self-care'. The significant factors were level of independence in 'self-care', 'locomotion' and 'communication' according to FIM, as well as working status, time since rehabilitation, age, gender, living alone or in family and preferred language.

Conclusions: Functional, social and personal factors are of similar importance when explaining selfperceived disability in the chronic phase of stroke. Some, but not all, of the factors are modifiable by the healthcare system. Therefore, a complex approach and involvement of medical, social and political systems is needed.

\section{Strengths and limitations of this study}

- In this study, a wide range of factors from functional, social and personal perspectives are used for explanation of the self-perceived disability in the chronic phase of stroke using regression analysis.

- The role of the healthcare system (including rehabilitation medicine) as well as social aspects of functioning has been evaluated.

- Participants of this study could choose between two languages (Latvian and Russian) to fulfil the questionnaire; therefore, a realistic picture of the poststroke population living in Latvia could be captured; however, a bias of results cannot be excluded.

- The level of independence at discharge was assessed by multiple clinicians.

\section{INTRODUCTION}

Disability is a unique, individual experience that is, or becomes, part of the human condition. In general, it is perceived as reduced functioning in any aspect of a person and his/her life. ${ }^{1}$ According to the suggested model from the WHO, these aspects can be divided into 'body functions and structures' and 'activity and participation'. ${ }^{2}$ However, functioning depends on the underlying health problem/s, as well as on the external (environmental factors) and internal (personal factors) background of the person. ${ }^{2}$ Disability is therefore composed of an interaction between two dimensions-functional limitation due to the underlying health condition and contextual factors. ${ }^{1}$ Another aspect is that disability varies over time, which makes it even more complex to assess and reduce with interventions. ${ }^{3}$

Currently stroke is one of the most prominent non-communicable health problems, ${ }^{4}$ 
especially in European countries, ${ }^{5}{ }^{6}$ due to the level of mortality, as well as the remaining impairments in the survivors after stroke. ${ }^{6-8}$ A wide variety of motor, sensory and cognitive impairments ${ }^{9}$ can influence the capacity and performance of everyday life activities. ${ }^{10}$ Moreover, stroke often results in reduced independence. ${ }^{11}$

Individual limitations and restrictions from a stroke depend on the context, such as access to support and the environment (both individual and social), as well as on these persons' subjective views and roles in society. ${ }^{12}$ Increased needs for health and social care, as well as loss of working ability for those of working age, are only a few of the many essential aspects of the burden of stroke. ${ }^{1}{ }^{12}$

The overall aim of rehabilitation is to maximally reduce these consequences and thereby reduce the disability, within the framework of a biopsychosocial approach. ${ }^{13}$ Both time and the quality of rehabilitation are reported as essential in reducing disability. ${ }^{14-16}$ Acute and postacute rehabilitation mainly focus on impairment reduction and improvement of independence in the activities of daily living. ${ }^{14}{ }^{17}$ Later, when the person returns to his/her usual environment, the focus may need to shift from a medical to a social one. ${ }^{18}$ Disability due to stroke causes complex and long-term emotional and financial burdens for the person, their family and the community. ${ }^{5} 61920$ Therefore, it is important to also acknowledge and assess disability from a societal perspective. This will lead to identifying needs, matching treatments and interventions, measuring outcomes and effectiveness, setting priorities and appropriately allocating resources. ${ }^{21}$

As in most European countries, stroke along with other cardiovascular diseases is one of the leading causes of mortality in Latvia. ${ }^{22}$ Moreover, it has been estimated that, although decreasing, mortality after stroke in Latvia remains one of the highest in the European Union. ${ }^{23}{ }^{24}$ Stroke is also the main reason for the officially approved disability status in Latvia. ${ }^{25}$ However, there is little information available on the outcomes for persons after stroke in Latvia. In 2003, 10 years after the restoration of independence in Latvia, McKevitt et $a l^{26}$ described experiences of persons after stroke in Riga, emphasising the cultural and social aspects as the determinants of disability experiences.

The aim of the study was to investigate how functional, social and personal factors explain the self-perceived level of disability in the chronic phase of stroke in persons living in Latvia.

\section{METHODS AND MATERIALS \\ Study design}

Cross-sectional study with retrospective data gathering.

\section{Data collection and study population}

A sample of convenience was used. Persons who had received specialised in-patient rehabilitation in the postacute phase of stroke at the Department of Neurorehabilitation in National Rehabilitation Centre (NRC) 'Vaivari', Latvia, from 1 January 2011 to 31 December 2013 were identified through the computerised hospital register. Prespecified data were gathered from the charts and entered into a file. This included the Functional Independence Measure (FIM) at discharge, diagnosis and date of stroke. Those living in the community were asked to participate in the study by telephone. After consent, the correspondence address was obtained and a set of questions that included current sociodemographic information, as well as WHO Disability Assessment Schedule 2.0 (WHODAS 2.0), ${ }^{21}$ were sent by mail or email. During the phone conversation, the preferred responding language (Latvian or Russian) was asked for. This was done because $37 \%$ of population in Latvia use Russian as their primary language. ${ }^{27}$ If the person could not fill out the questionnaire themselves, it could be performed by their next of kin.

Inclusion criteria were: first-time diagnosis of stroke (International Classification of Diseases (ICD)-10 codes I60-I $67^{28}$ ) clinically determined by the attending physician in acute care according to the $\mathrm{WHO}$ criteria $^{29}$ and confirmed by CT; age of at least 18 years, and at least 9 months poststroke.

Out of the 600 persons who were selected for the study, 49 refused to participate, 50 were deceased and 119 were not reachable. Out of the 382 persons who agreed to participate in the study, 255 completed the questionnaire and sent it back. The flow chart of the study population is shown in figure 1 .

\section{Outcome variables}

Dependent variables

The WHODAS 2.0 36-item self-assessment questionnaire was used for evaluation of the disability level. It is directly linked to the 'activity and participation' component of

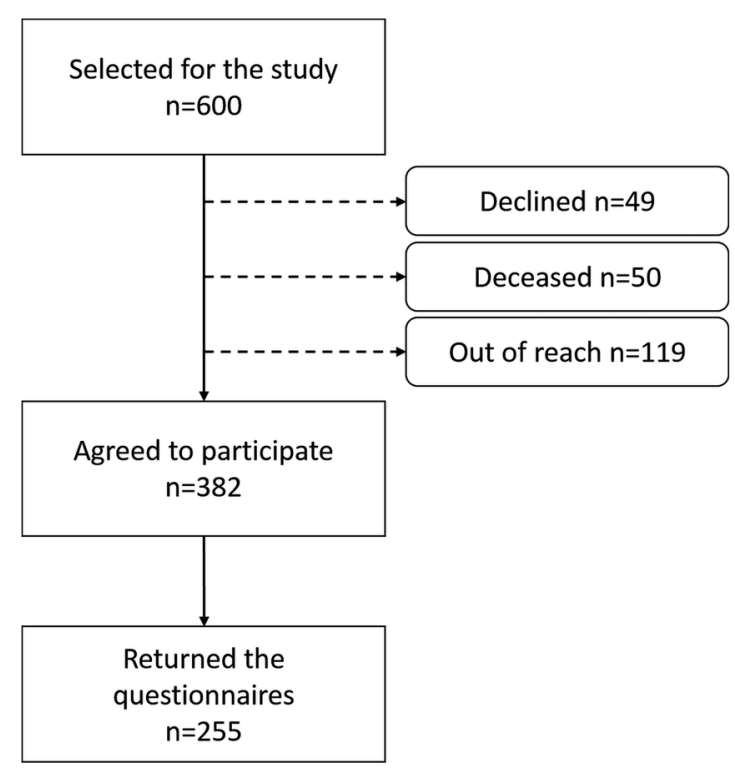

Figure 1 Study flow chart. 
International Classification of Functioning, Disability and Health and has shown good psychometric properties (validity, reliability, sensitivity to changes and item-response characteristics) ${ }^{21}$ WHODAS 2.0 consists of 36 items in six domains. Each item is scored on a five-level scale $(1=$ 'no difficulties', $5=$ 'extreme difficulties or cannot do'). Recoded scores were summed and converted into a metric ranging from 0 (no disability) to 100 (full disability $)^{21}$ for the following outcomes:

- Domain 1: 'cognition' (understanding and communicating)—six items;

- Domain 2: 'mobility' (moving and getting around) five items;

- Domain 3: 'self-care' (attending to one's hygiene, dressing, eating and staying alone)-four items;

- Domain 4: 'getting along' (interacting with other people)—five items;

- Domain 5, part 1: 'household activities' (domestic responsibilities)—four items;

- Domain 5, part 2: 'work or school activities'-four items;

- Domain 6: 'participation' (joining in community activities, participating in society)—eight items;

- Total WHODAS 2.0 score.

For the WHODAS 2.0 data set, the simple approach to missing data and the complex scoring method were used (the scores of each item were recoded according to the suggested algorithm). ${ }^{21}$ The simple approach to the missing data means that if responses in one or two items were missing, the mean raw score of the corresponding domain replaced the missing response. In a case where more than two responses were missing in the data set, the response remained missing and the mean score was not used. Complex scoring is based on the 'item-response theory' and each item's level of difficulty is taken into account and weighted accordingly. ${ }^{21}$

\section{Independent variables}

FIM was used to define the levels of independence at discharge from rehabilitation. ${ }^{30}$ It is used as a routine clinical assessment tool in NRG 'Vaivari'. The evaluation is conducted by members of the rehabilitation team. FIM consists of 18 items, each scored on a seven-point scale (1-7). Grades 7 and 6 are used to describe complete and modified independence, respectively. Grades 5-1 are used to describe different levels of dependence, which are supervision, minimal assistance, moderate assistance, maximal assistance and total assistance, respectively. For this study, the data from FIM at discharge from rehabilitation were used and the items were grouped under six domains-'self-care', 'sphincter', 'transfer', 'locomotion', 'communication', 'social cognition'. The overall results for each domain were presented in a trichotomised way. The domains were coded as ' 1 ' or 'totally dependent' if any of the items in the domain was scored as ' 1 ' or '2', '2' or 'partially dependent' if any of items in the domain was scored as ' 3 ', ' 4 ' or ' 5 ', but none as ' 1 ' or ' 2 ' and 3 , or 'independent' if all items were scored as ' 6 ' and ' 7 '.
Further independent variables that were included in the questionnaire were status of employment (working or not after stroke), time after discharge from rehabilitation (months). 'Working' was defined as persons who had paid or unpaid work, were self-employed, studied or were performing household duties.

Personal factors, such as age, gender, preferred language (Latvian or Russian), education, place of living (city or countryside) and living situation (alone or in a family), were used as secondary explanatory variables. Time (weeks) from stroke onset until start of rehabilitation, length of rehabilitation (days) and type of diagnosis according to ICD-10 were seen as potential cofounding variables.

\section{Data analysis}

Demographic and clinical characteristics of the population were described using frequencies, means and medians. Stepwise multiple linear regression analysis ${ }^{31}$ was used to predict the summary scores for each of the seven domains and the total score of WHODAS 2.0. The initial model for regression analysis is illustrated in figure 2.

The steps for the multiple regression model building were as follows:

Step 1: univariate regression analyses were done to evaluate the association between each of the 16 predictor variables and the outcome.

Step 2: multiple regression analyses with all predictor variables with $\mathrm{p}<0.25$ at step 1 were included in the model.

Step 3: those variables which showed $p>0.25$ were excluded from the model and multiple regression analysis with variables, significant in step 2 , was performed. Step 4: the variables rejected at step 1 were reinserted one by one in the model with the remaining variables from step 3. If the variable turned out to be significant $(\mathrm{p}<0.05)$, it was left in the model.

The best model was selected by comparing models with an $\mathrm{F}$ test. If the two models were significantly different ( $p>0.05$ ), the model with higher $\mathrm{R}^{2}$ values was chosen. If the models were not significantly different, the model with the least amount of explanatory variables was chosen.

For each of the final models, analyses were conducted to ensure no violation of the assumptions of normality, linearity, multicollinearity and homoscedasticity.

Each of the significant factors in the final model in turn was excluded from the model and changes of $\mathrm{R}^{2}$ were reported, to illustrate the factors' unique contributions to the model.

Work as an explanatory factor was excluded from the analysis of domain 5.2 since this domain evaluates the ability to work and was not fulfilled by those who were unemployed.

Statistical analyses were made with SPSS (V.21.0).

\section{RESULTS}

\section{Descriptive statistics}

The characteristics of the study population are shown in table 1. There were no significant differences in the 


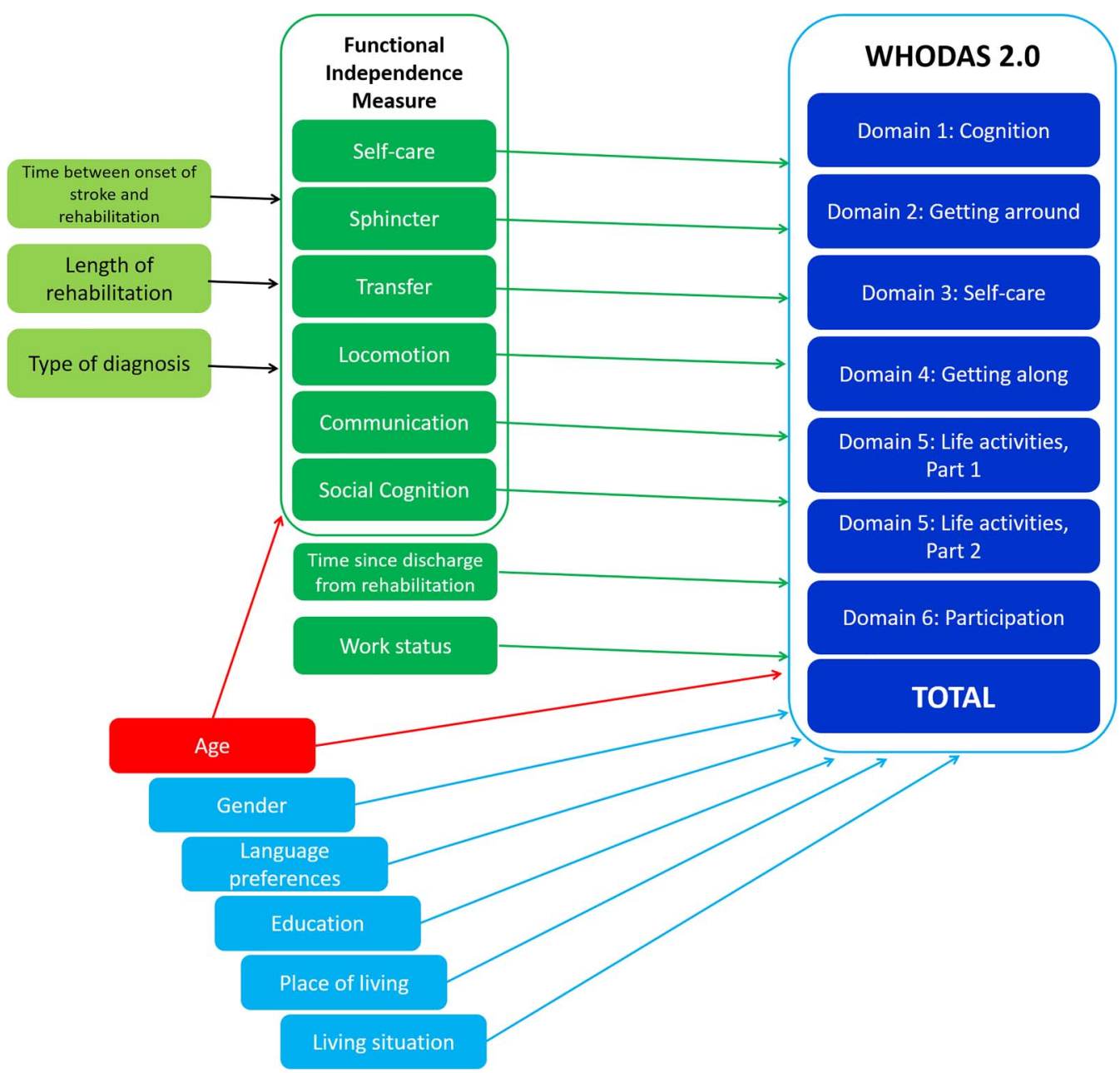

Figure 2 Initial model for the analysis. WHODAS 2.0, WHO Disability Assessment Schedule 2.0.

basic characteristics between the selected and final study populations. Out of the 50 persons who were working, 39 were of working age (18-60 years) and 11 were above the official age of retirement. The group consisted of $52 \%$ males and the mean age was 63 (SD 13) years (range 22-92). The median time after discharge from rehabilitation was 1 year and 9 months. Most of them were independent at the time of discharge from rehabilitation (figure 3). However, the median level of self-perceived disability, evaluated by WHODAS 2.0, was $52 \%$ (figure 4).

\section{Multiple regression analysis}

The models explained $23-43.5 \%$ of the variance in the outcomes. The explained variance of the total WHODAS 2.0 score was $40.8 \%$. The domains of 'mobility' and 'self-care' were explained best, but the most poorly explained domain was 'cognition'. For detailed results, see table 2.

The dependence level of 'self-care' at discharge from rehabilitation was included and significant in the final explanatory model in five out of seven analysed domains, as well as in the total WHODAS 2.0 score. Results indicated that being dependent at discharge led to a higher level of perceived disability. 'Locomotion' was significantly related to the 'mobility, 'self-care', 'life activities: work or school' and 'participation' domains. Similarly, persons recognised by rehabilitation professionals as independent in 'communication' at discharge perceived fewer problems in the domains of 'cognition', 'getting along' and the total WHODAS 2.0 scores.

Work status was the factor that showed association with all domains of WHODAS 2.0, with the exception of 'getting along'. Results indicated that those who were working reported fewer problems in functioning when other variables in the final model were held constant.

A longer time since discharge was a significant factor in explaining worse 'self-care' and total scores of WHODAS 2.0. Age was also a significant factor regarding 'mobility' and 'getting along' and the total score of WHODAS 2.0, indicating that older persons experienced greater disability. Between other personal factors chosen for the analysis, gender, language and living situation were those of significance. Males reported higher levels of disability in the 'cognition' and 'getting along' domains. Those who preferred to fill out the questionnaire in Latvian reported fewer problems in functioning in the 'getting along', 'life activities' and 'participation in society' domains, as well 
Table 1 Characteristics of the study population

\begin{tabular}{|c|c|c|c|}
\hline Characteristic & $\begin{array}{l}\text { Selected for the study } \\
n=600 \\
N(\%)\end{array}$ & $\begin{array}{l}\text { Agreed to participate } \\
n=382 \\
N(\%)\end{array}$ & $\begin{array}{l}\text { Returned the } \\
\text { questionnaire } \\
\mathrm{n}=255 \\
\mathrm{~N}(\%)\end{array}$ \\
\hline \multicolumn{4}{|l|}{ Diagnosis (ICD-10) } \\
\hline 160 & $9(1.5)$ & $6(1.5)$ & $3(1.2)$ \\
\hline 161 & $85(14.2)$ & $53(13.9)$ & $34(13.3)$ \\
\hline 162 & $3(0.5)$ & $2(0.5)$ & $1(0.4)$ \\
\hline 163 & $490(81.7)$ & $315(82.5)$ & $215(84.3)$ \\
\hline 164 & $10(1.7)$ & $6(1.6)$ & $2(0.8)$ \\
\hline \multicolumn{4}{|c|}{ Time between onset of stroke and beginning of rehabilitation (weeks) } \\
\hline Median (IQR) & $13(9-18)$ & $13(9-18)$ & $13(9-18.25)$ \\
\hline Minimum-maximum & $1-125$ & $1-72$ & $1-68$ \\
\hline \multicolumn{4}{|l|}{ Length of rehabilitation (days) } \\
\hline Median (IQR) & $13(9-18)$ & $15(9-18)$ & $15(9-18)$ \\
\hline Minimum-maximum & $0-47$ & $0-46$ & $0-46$ \\
\hline \multicolumn{4}{|c|}{ Time since discharge from rehabilitation (months) } \\
\hline Median (IQR) & - & - & $20(12-28)$ \\
\hline Minimum-maximum & - & - & $6-52$ \\
\hline \multicolumn{4}{|l|}{ Age (years) } \\
\hline Median (IQR) & $66(57-74)$ & $65(56-73)$ & $64(56-73)$ \\
\hline Minimum-maximum & $21-92$ & $21-92$ & 22-92 \\
\hline \multicolumn{4}{|l|}{ Gender } \\
\hline Male & $320(53.3)$ & $197(51.6)$ & $134(52.5)$ \\
\hline Female & $280(46.7)$ & $185(48.4)$ & $121(47.5)$ \\
\hline \multicolumn{4}{|l|}{ Language preferences } \\
\hline Latvian & - & - & $188(73.7)$ \\
\hline Russian & - & - & $67(26.3)$ \\
\hline \multicolumn{4}{|l|}{ Education } \\
\hline Primary & - & - & $41(16.1)$ \\
\hline Secondary & - & - & $124(48.8)$ \\
\hline Higher & - & - & $72(28.3)$ \\
\hline Studies ongoing & - & - & $1(0.4)$ \\
\hline Other & - & - & $16(6.3)$ \\
\hline \multicolumn{4}{|l|}{ Place of living } \\
\hline City & - & - & $191(74.9)$ \\
\hline Countryside & - & - & $64(25.1)$ \\
\hline \multicolumn{4}{|l|}{ Living in situation } \\
\hline Alone & - & - & $44(22.0)$ \\
\hline Family & - & - & $156(78.05)$ \\
\hline \multicolumn{4}{|l|}{ Working status } \\
\hline Working & - & - & $50(19.7)$ \\
\hline Not working & - & - & $204(80.3)$ \\
\hline \multicolumn{4}{|l|}{ Level of disability WHODAS 2.0} \\
\hline No disability (0-4\%) & - & - & $2(0.9)$ \\
\hline Low disability (5-24\%) & - & - & $26(12.3)$ \\
\hline Moderate disability (25-49\%) & - & - & $73(34.6)$ \\
\hline Severe disability (50-95\%) & - & - & $110(47.9)$ \\
\hline Complete disability (96-100\%) & - & - & 0 \\
\hline
\end{tabular}

ICD, International Classification of Diseases; WHODAS 2.0, WHO Disability Assessment Schedule 2.0.

as in total WHODAS 2.0 scores. Persons who lived alone experienced greater problems in 'participation in society' than those who lived in a family.

\section{DISCUSSION}

This study suggests that self-perceived disability in the chronic phase of stroke cannot be explained solely by the level of independence in daily activities at discharge from rehabilitation. Other factors, such as social and personal ones, are of similar importance. Some of the factors are modifiable by the healthcare system through improved functioning. However, others, such as work situation and language preferences, are not possible to influence from the healthcare system but are a responsibility of society as a whole. 
Figure 3 Shifts between levels of dependence at discharge from rehabilitation centre by FIM domains. FIM, Functional Independence Measure.

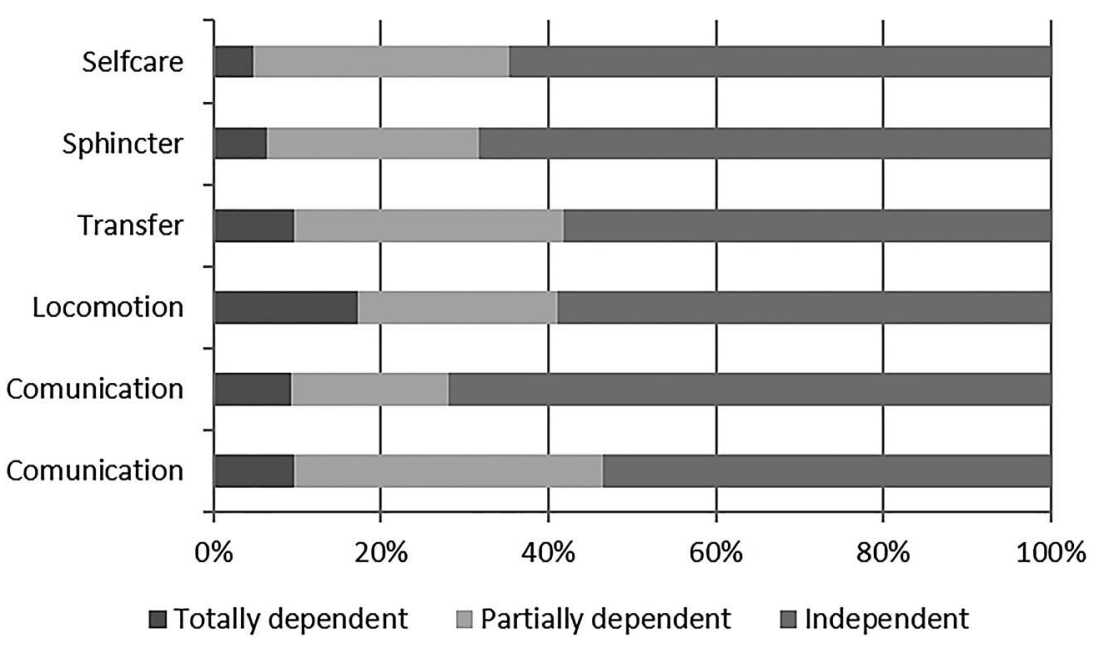

Functional, social and personal factors chosen for the analysis could explain up to almost half of the variance in a person's experience of life after stroke, depending on the analysed life aspect. These factors explained such domains as 'mobility' and 'self-care' rather well. Both these domains represent the issues of basic skills of physical functioning. The models explained considerably less well the perception of 'understanding and communication', as well as 'interaction with other people'. These tasks require complicated multilevel skills that are more challenging to evaluate than physical functioning.

'Participation in society' was also rather poorly explained in comparison to other domains. Moreover, this domain, along with 'household activities', was reported as most problematic for the study population. That is of interest and importance because participation in society involves the usage of complex skills and navigation in everyday life.

The status in the present study population varied in full range-from no disability to extreme disability. The overall levels of disability were more severe when compared with those in a stroke population in Spain gathered at a similar period after the event. ${ }^{32}$ However, the population for this study was recruited using data from the rehabilitation centre that provides in-patient rehabilitation services versus the Spanish population which got its data from an epidemiological study. Therefore, the functional level in this study population could be reported as worse compared with that in the overall stroke population.

The overall goal of rehabilitation is to enable a person to live a meaningful life according to his/her wish, that is, in direct line with the concept of participation in
Figure 4 Box plot on WHODAS 2.0 results by domain. WHODAS 2.0, WHO Disability Assessment Schedule 2.0.

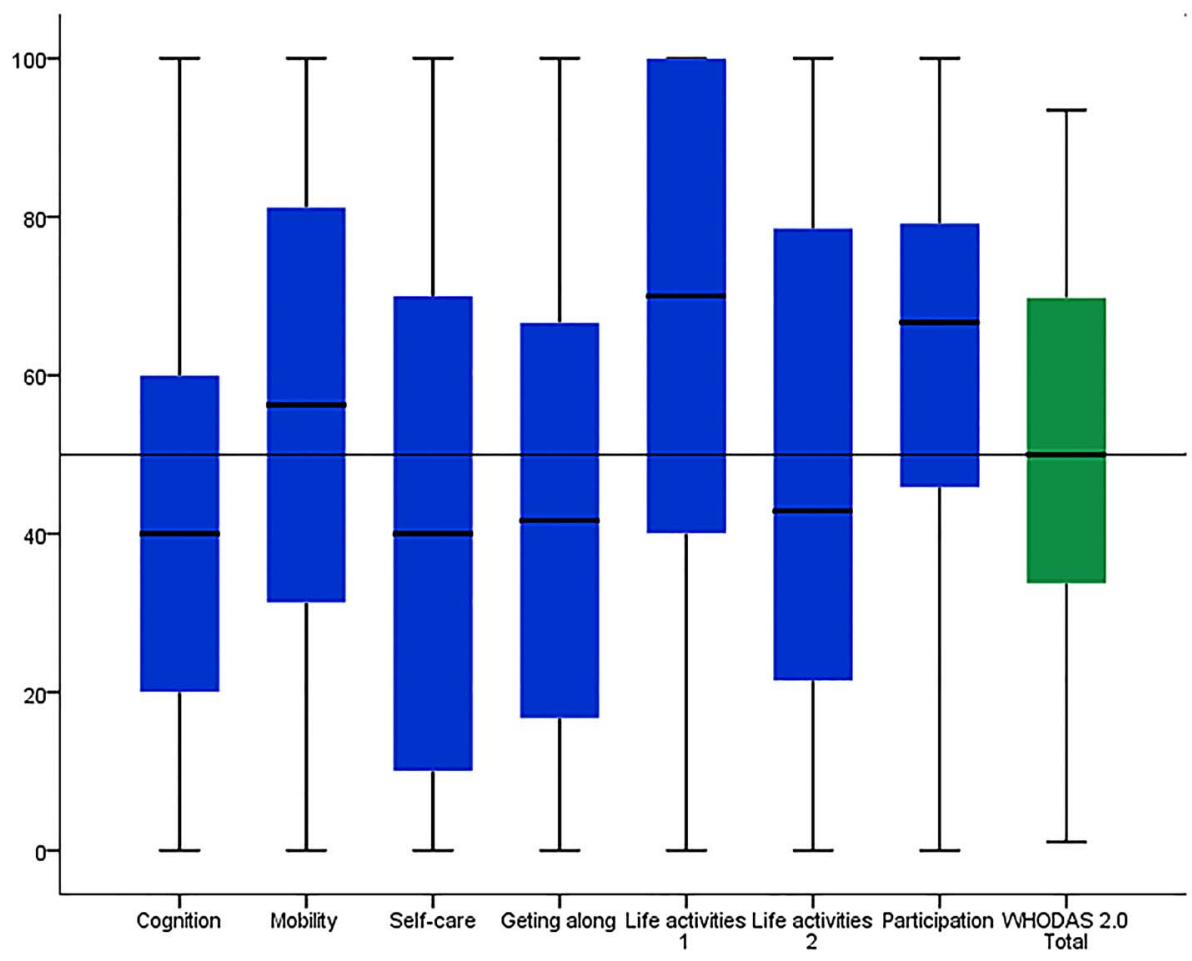




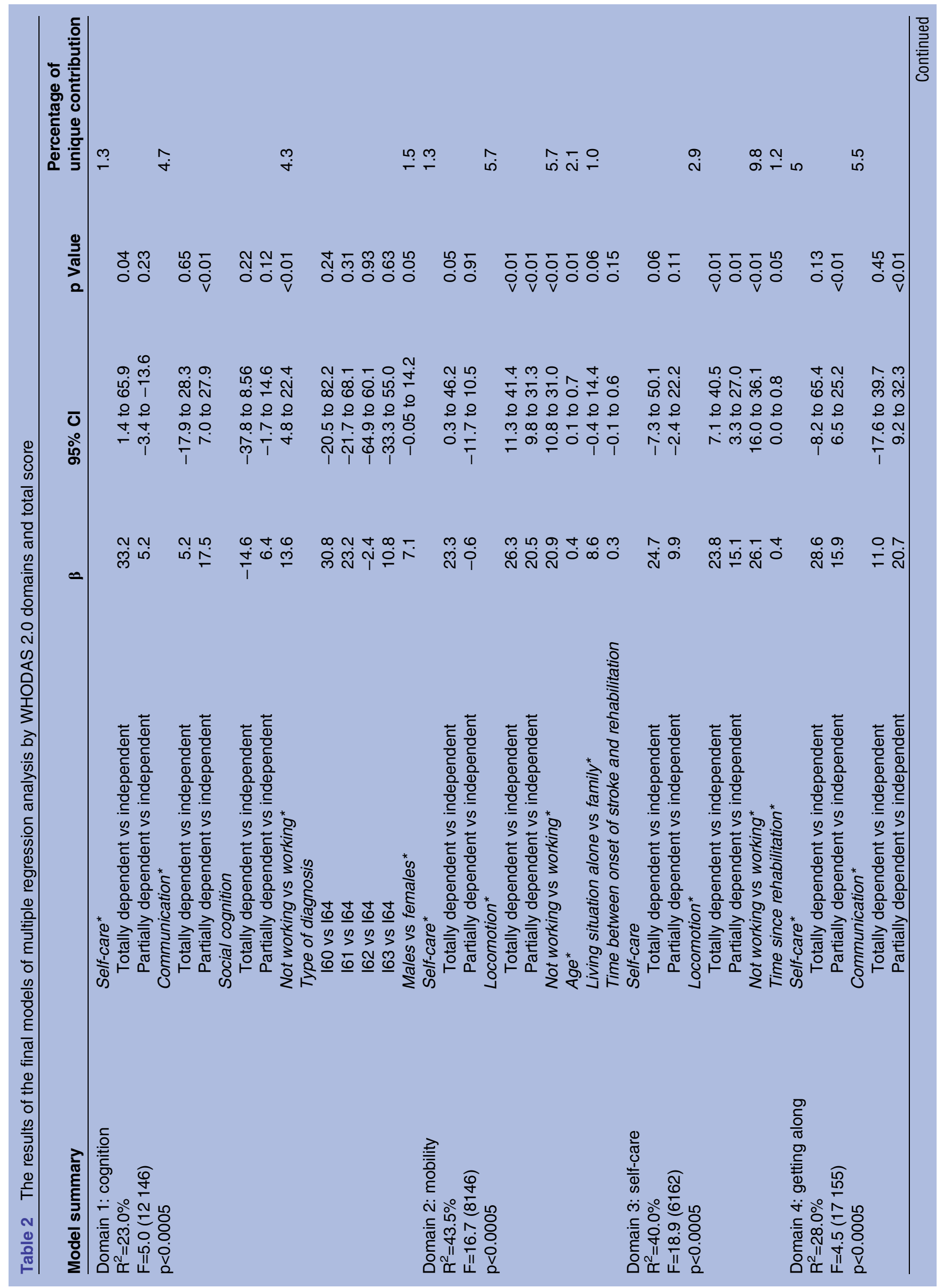




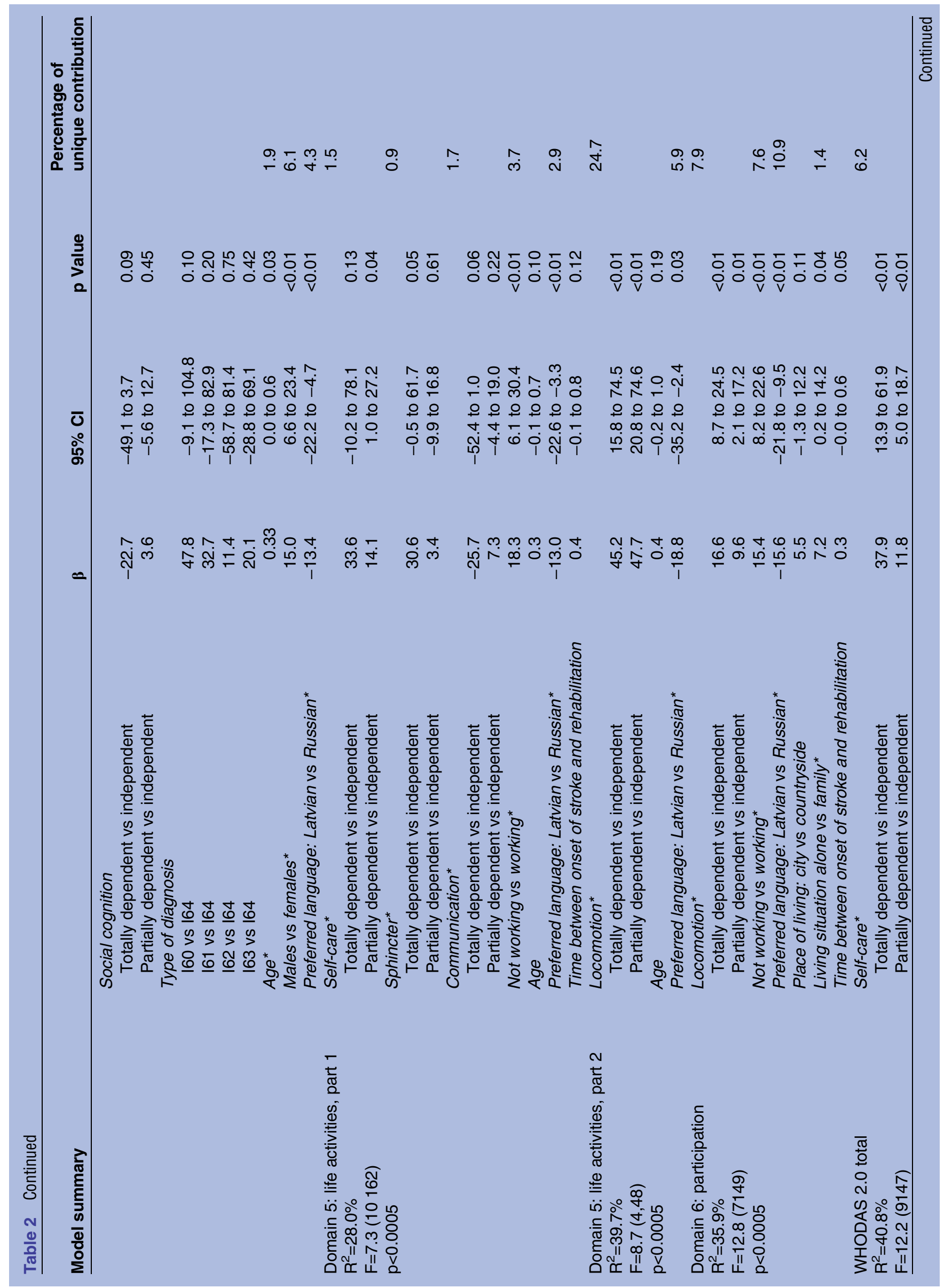




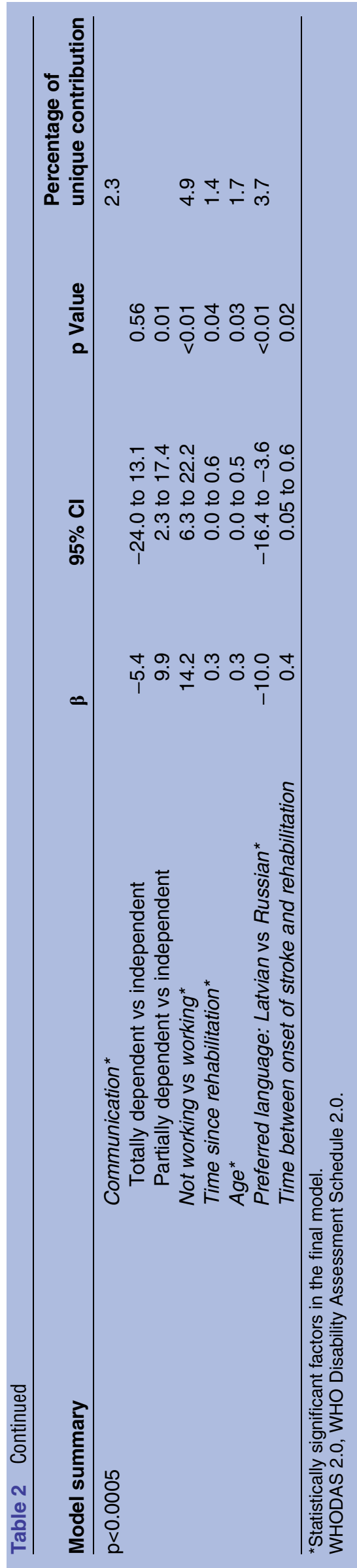

society. However, the field of physical and rehabilitation medicine directly after stroke is oriented to the medical assessment and the functional aspects and focuses mainly on the improvement of independence in basic daily activities. These aspects, in turn, give a basis for better participation in society, ${ }^{33} 34$ and thereby on the quality of life. That gives support to the role of the rehabilitation process and the results of our study also support this. Either 'self-care' or 'locomotion', or both were important in explaining all outcomes. Being independent in locomotion is of importance not only for the 'mobility' domain of WHODAS 2.0, where there is direct theoretical relationship, but also for perception of problems in 'participation in society', as well as for 'work activities' for those who are employed.

The level of independence or amount of care needed in six domains of daily activities was used as an explanatory factor in the study. When discharging patients from the specialised in-patient rehabilitation unit, rehabilitation professionals evaluate a person's ability to do simple tasks. This evaluation is used to establish whether rehab has been effective. However, more than one person is assessing patients that may lead to a bias in the results generated from this evaluation. However, the definition of FIM scoring is detailed and excellent inter-rater reliability has been reported for the instrument. ${ }^{35}$

Nevertheless, the ability to perform activities independently cannot give the whole picture of the disability experience. $^{34}$ The results of this study highlight the importance of factors that are beyond the scope of dependence/independence aspects and thus beyond the field of rehabilitation medicine.

In the data analysis, work was the most common important factor that explains the outcome for persons after stroke. One could argue that returning to work depends on the stroke outcome. However, our results showed that employment had the highest unique contribution in certain domains, even when controlling for other important factors. Returning to work could lead to more positive health outcomes and quality of life, ${ }^{36}$ and most probably it does not depend on the work load (part-time or full-time employment). ${ }^{37}$ The ability to return to work after experiencing a disabling condition is in the interests of politicians and decision-makers for its contribution to the economy. Moreover, work is considered to be among the most important meaningful activities of the lives of many people. ${ }^{38}$ It is of great importance in Latvian society and not only for those of working age. Of those who returned to work, $22 \%$ were over the retirement age. This could most likely be explained by each person's financial situation and returning to work may have been a financial necessity. Another explanation could be the historical importance of hard work and 'self-sacrifice' ideology, which McKevitt $e t a l^{26}$ pointed out when analysing experiences of persons after stroke living in Riga at the beginning of the previous decade. The person who works has a clearly defined role that allows him/her to make a 
meaningful contribution to society. Although other activities attributable to participation in society are also of importance to the satisfaction with personal roles and quality of life, ${ }^{39}$ in our opinion the recognition of these roles is lacking in society.

Time is a factor that has a rather strong theoretical role in the experience of disability. ${ }^{3}$ However, the evidence for it is controversial. For instance, a recent study showed that the functional and motor outcomes did not differ between 2 months and 5 years after stroke, ${ }^{40}$ but White $e t a t^{41}$ reported that the functioning of stroke survivors changes significantly over time and social support and social services are also of importance. The results of this study suggest that the time that has elapsed since a person has been discharged from a rehabilitation centre is of importance in 'self-care' activities and the total WHODAS 2.0 score and the role of this dynamic factor, if compared with other factors in the model, is rather small. Therefore, it looks as though the time that has passed after the disabling event is not a factor in and of itself, but gives a frame of reference in which the changes occur. Conversely, age is an independent factor that leads to better outcomes for younger persons. ${ }^{16} 42$ In this study, the statistical contribution of age is rather small, but significant in several aspects of the disability experience.

There was an obvious discrepancy between persons, depending on the language they preferred. Those who chose to fill out the questionnaire in Russian experienced greater problems in self-perceived disability in the 'participation' domain versus those who preferred Latvian. This aspect cannot directly influence an outcome of disability perception. The explanations for this significant association could be many. Some studies analysed differences between ethnic subgroups in an American population and explained these differences by the poorer neurological outcomes after stroke. ${ }^{43} 44$ Since the level of dependence at discharge did not differ between the two groups in this study, there is no reason to believe that this could be the cause. Kasmel et $a t^{45}$ found that self-reported health and health behaviour were similar in all three Baltic States, but different from results reported in Finland. As a possible explanation, they mentioned the former economic and political stability in the country. Other different 'sociocultural' explanations have been suggested such as organisational barriers of healthcare and issues in the communication between healthcare professionals and patients. ${ }^{46}$ Our personal experience shows that most of the healthcare professionals have skills to be able to communicate in both languages, depending on the patient's preference. Since the main importance of the language factor was on the 'participation domain', the assumption is that reported differences could be due to different health behaviours, beliefs and values between Russian and Latvian speakers. However, the issue of social integration cannot be excluded. To analyse the interactions between all those aspects, further research on this topic should be conducted. There may also be a bias of results due to usage of two translations of WHODAS 2.0. However, using two translations of WHODAS 2.0 allowed us capture a realistic picture of the poststroke population living in Latvia, regardless of language preference.

WHODAS 2.0 is an instrument which is designed to assess self-perceived functioning in the main aspects of disability. The perception of disability experience and recognition of problems can differ between the persons experiencing the condition and the professionals who perform the evaluation. ${ }^{47}$ That can lead to random variance due to the personal attitudes towards the situation, rather than defined personal factors, used for this study.

The results of this study underline the importance of the rehabilitation process. However, the consequences of stroke and its impact on lives depend on a complex entirety that is formed by interactions of different factors. Both modifiable and non-modifiable factors are included. Recognition of those factors that could be modified gives room for improvements in systems and services. Also, recognition of the factors that are important, but will remain unchangeable, would help in setting the focus for service improvements. The results of an Estonian study that aimed at testing the evaluation of needs for social rehabilitation highlighted the unclear and mixed roles between medical and social rehabilitation, also pointing out other services that should be involved in the process. ${ }^{48}$

\section{CONCLUSIONS}

The functional, social and personal factors used in this study could explain up to almost half of the variance in self-perceived level of disability in the chronic phase of stroke in a Latvian stroke population.

The social and personal aspects of a person and their level of independence in daily activities at discharge from an in-patient rehabilitation setting showed equal contribution to the outcome.

Therefore, this highlights the importance of medical and social systems in modification of important factors towards better outcomes and as well as being continuous, the process should be interactive. However, more research is needed to identify other important factors and determine the best approaches for addressing the problems in the most productive manner.
Author affiliations
${ }^{1}$ Department of Rehabilitation, Riga Stradinsš University, Riga, Latvia
${ }^{2}$ Department of Secondary Outpatient Care, Psycho-neurological Hospital for Children "Ainaži”, Ainaži, Latvia
${ }^{3}$ Section for Clinical Neuroscience and Rehabilitation, University of Gothenburg, the Sahlgrenska Academy, Gothenburg, Sweden
${ }^{4}$ Sunnaas Rehabilitation Hospital, Nesoddtangen, Norway
${ }^{5}$ Centre for Person-Centred Care (GPCC), Sahlgrenska Academy, University of Gothenburg, Gothenburg, Sweden 
Acknowledgements This publication has been produced during GB's scholarship period at the University of Gothenburg, thanks to the Visby Programme of the Swedish Institute.

Contributors GB has been involved in the design of the study, data collection, performing analysis, interpretation of the results and writing. BS has been involved in data collection and interpretation of the results. AV has been involved in the design of the study and interpretation of the results. KSS has been involved in the design of the study, interpretation of the results and writing. All authors have read and approved the final manuscript.

Funding This research received no specific grant from any funding agency in the public, commercial or not-for-profit sectors.

Competing interests None declared.

Ethics approval The study was conducted to conform to the ethical principles of the Declaration of Helsinki and was approved by the Ethics Committee of Riga Stradinš̌ University, Latvia (27 September 2012).

Provenance and peer review Not commissioned; externally peer reviewed.

Data sharing statement The data from this study are available on reasonable request from the corresponding author.

Open Access This is an Open Access article distributed in accordance with the Creative Commons Attribution Non Commercial (CC BY-NC 4.0) license, which permits others to distribute, remix, adapt, build upon this work noncommercially, and license their derivative works on different terms, provided the original work is properly cited and the use is non-commercial. See: http:// creativecommons.org/licenses/by-nc/4.0/

\section{REFERENCES}

1. WHO. World report on disability. Geneva: World Health Organization, 2011.

2. WHO. International classification of functioning, disability and health. Geneva: World Health Organization, 2001.

3. Jahiel RI, Scherer MJ. Initial steps towards a theory and praxis of person-environment interaction in disability. Disabil Rehabil 2010;32:1467-74.

4. WHO. World Health Statistics 2014. Italy: World Health Organization, 2014.

5. Lopez AD, Mathers CD, Ezzati M, et al. Global and regional burden of disease and risk factors, 2001: systematic analysis of population health data. Lancet 2006;367:1747-57.

6. Vos $T$, Flaxman AD, Naghavi M, et al. Years lived with disability (YLDs) for 1160 sequelae of 289 diseases and injuries 1990-2010: a systematic analysis for the Global Burden of Disease Study 2010. Lancet 2012;380:2163-96.

7. Mukherjee D, Patil CG. Epidemiology and global burden of stroke. World Neurosurg 2011;76:S85-90.

8. Feigin VL, Forouzanfar MH, Krishnamurthi R, et al. Global and regional burden of stroke during 1990-2010: findings from the Global Burden of Disease Study 2010. Lancet 2014;383: 245-54

9. WHO STEPS stroke manual. The WHO STEPwise approach to stroke surveillance. Geneva, 2006

10. Alguren B, Lundgren-Nilsson A, Sunnerhagen KS. Functioning of stroke survivors - a validation of the ICF Core Set for stroke in Sweden. Disabil Rehabil 2010;32:551-9.

11. Vincent C, Desrosiers J, Landreville $P$, et al. Burden of caregivers of people with stroke: evolution and predictors. Cerebrovasc Dis 2009;27:456-64.

12. Walsh ME, Galvin R, Loughnane $\mathrm{C}$, et al. Community re-integration and long-term need in the first five years after stroke: results from a national survey. Disabil Rehabil 2015;37:1834-8.

13. Section of Physical and Rehabilitation Medicine Union Européenne des Médecins Spécialistes (UEMS); European Board of Physical and Rehabilitation Medicine; Académie Européenne de Médecine de Réadaptation; European Society for Physical and Rehabilitation Medicine. White book on physical and rehabilitation medicine in Europe. Eura Medicophys 2006;42: 292-332.

14. Quinn TJ, Paolucci S, Sunnerhagen KS, et al. Evidence-based stroke rehabilitation: an expanded guidance document from the European stroke organisation (ESO) guidelines for management of ischaemic stroke and transient ischaemic attack 2008. J Rehabil Med 2009;41:99-111.
15. Lindsay $\mathrm{P}$, Furie KL, Davis SM, et al. World stroke organization global stroke services guidelines and action plan. Int J Stroke 2014;9 (Suppl A100):4-13.

16. Meyer MJ, Pereira S, McClure A, et al. A systematic review of studies reporting multivariable models to predict functional outcomes after post-stroke inpatient rehabilitation. Disabil Rehabil 2015;37:1316-23.

17. Ward A, Gutenbrunner C, Giustini A, et al. A position paper on Physical \& Rehabilitation Medicine programmes in post-acute settings. Union of European Medical Specialists Section of Physical \& Rehabilitation Medicine (in conjunction with the European Society of Physical \& Rehabilitation Medicine). J Rehabil Med 2012;44:289-98.

18. Takac P, Petrovicova J, Delarque A, et al. Position paper on PRM and persons with long term disabilities. Eur J Phys Rehabil Med 2014;50:453-64.

19. Kankeu HT, Saksena $P, X u K$, et al. The financial burden from non-communicable diseases in low- and middle-income countries: a literature review. Health Res Policy Syst 2013;11:31.

20. Carod-Artal FJ, Egido JA. Quality of life after stroke: the importance of a good recovery. Cerebrovasc Dis 2009;27(Suppl 1):204-14.

21. Measuring Health and Disability. Manual for WHO Disability Assessment Schedule. WHODAS 2.0. Geneva: World Health Organization, 2010.

22. WHO. Noncommunicable diseases. Country profiles 2014. Geneva, Switzerland: World Health Organization, 2014

23. Nichols M, Townsend N, Luengo-Fernandez R, et al. European Cardiovascular Disease Statistics. Brussels: European Heart Network and Sophia Antipolis: European Society of Cardiology, 2012.

24. Nichols M, Townsend N, Scarborough $\mathrm{P}$, et al. Cardiovascular disease in Europe 2014: epidemiological update. Eur Heart $J$ 2014;35:2950-9.

25. The Health and Work Expertise State Medical Commission: Public Review 2013. Riga, Latvia: Ministry of Welfare of the Republic of Latvia, 2014

26. McKevitt C, Luse A, Wolfe $\mathrm{C}$. The unfortunate generation: stroke survivors in Riga, Latvia. Soc Sci Med 2003;56:2097-108.

27. The results of Population Census in 2011. Newsletter. Latvia: Central Statistical Bureau, 2012.

28. WHO. International Classification of Diseases and Related Health Problems: Tenth Revision. Version for 2010. Geneva: World Health Organization, 2010.

29. Stroke-1989. Recommendations on stroke prevention, diagnosis, and therapy. Report of the WHO Task Force on Stroke and other Cerebrovascular Disorders. Stroke 1989;20:1407-31.

30. Cournan M. Use of the functional independence measure for outcomes measurement in acute inpatient rehabilitation. Rehabil Nurs 2011;36:111-17.

31. Bursac Z, Gauss CH, Williams DK, et al. Purposeful selection of variables in logistic regression. Source Code Biol Med 2008;3:17.

32. de Pedro-Cuesta J, Garcia-Sagredo P, Alcalde-Cabero E, et al. Disability transitions after 30 months in three communitydwelling diagnostic groups in Spain. PLOS ONE 2013;8 e77482.

33. Skolarus LE, Burke JF, Brown DL, et al. Understanding stroke survivorship: expanding the concept of poststroke disability. Stroke 2014;45:224-30.

34. Mayo NE, Bronstein D, Scott SC, et al. Necessary and sufficient causes of participation post-stroke: practical and philosophical perspectives. Qual Life Res 2014;23:39-47.

35. Ottenbacher KJ, Hsu Y, Granger CV, et al. The reliability of the functional independence measure: a quantitative review. Arch Phys Med Rehabil 1996;77:1226-32.

36. Carlier BE, Schuring M, Lotters FJ, et al. The influence of re-employment on quality of life and self-rated health, a longitudinal study among unemployed persons in the Netherlands. BMC Public Health 2013;13:503.

37. Pack TG, Szirony GM, Kushner JD, et al. Quality of life and employment in persons with multiple sclerosis. Work 2014;49: 281-7.

38. Barclay-Goddard R, Ripat J, Mayo NE. Developing a model of participation post-stroke: a mixed-methods approach. Qual Life Res 2012;21:417-26.

39. Mayo NE, Anderson S, Barclay R, et al. Getting on with the rest of your life following stroke: a randomized trial of a complex intervention aimed at enhancing life participation post stroke. Clin Rehabil 2015;29:1198-211.

40. Meyer S, Verheyden G, Brinkmann N, et al. Functional and motor outcome 5 years after stroke is equivalent to outcome at 2 months: 
follow-up of the collaborative evaluation of rehabilitation in stroke across Europe. Stroke 2015;46:1613-19.

41. White $\mathrm{JH}$, Alston MK, Marquez JL, et al. Community-dwelling stroke survivors: function is not the whole story with quality of life. Arch Phys Med Rehabil 2007;88:1140-6.

42. Knoflach $M$, Matosevic B, Rucker M, et al. Functional recovery after ischemic stroke-a matter of age: data from the Austrian Stroke Unit Registry. Neurology 2012;78:279-85.

43. Lisabeth LD, Sanchez BN, Baek J, et al. Neurological, functional, and cognitive stroke outcomes in Mexican Americans. Stroke 2014;45:1096-101.

44. Burke JF, Freedman VA, Lisabeth LD, et al. Racial differences in disability after stroke: results from a nationwide study. Neurology 2014;83:390-7.
45. Kasmel A, Helasoja V, Lipand A, et al. Association between health behaviour and self-reported health in Estonia, Finland, Latvia and Lithuania. Eur J Public Health 2004;14:32-6.

46. Betancourt JR, Green AR, Carrillo JE, et al. Defining cultural competence: a practical framework for addressing racial/ethnic disparities in health and health care. Public Health Rep 2003;118:293-302.

47. Robinson CA, Shumway-Cook A, Ciol MA, et al. Participation in community walking following stroke: subjective versus objective measures and the impact of personal factors. Phys Ther 2011;91:1865-76.

48. Hanga $K$, DiNitto $D$, Leppik $L$. Initial assessment of rehabilitation needs using the WHODAS 2.0 in Estonia. Disabil Rehabil 2016;38:260-7. 

between functional, social and personal factors and the level of self-perceived disability--a cross-sectional study

Guna Berzina, Baiba Smilskalne, Anita Vetra and Katharina Stibrant Sunnerhagen

BMJ Open 2016 6:

doi: 10.1136/bmjopen-2015-010327

Updated information and services can be found at: http://bmjopen.bmj.com/content/6/6/e010327

\begin{abstract}
These include:
References This article cites 38 articles, 9 of which you can access for free at: http://bmjopen.bmj.com/content/6/6/e010327\#BIBL

Open Access This is an Open Access article distributed in accordance with the Creative Commons Attribution Non Commercial (CC BY-NC 4.0) license, which permits others to distribute, remix, adapt, build upon this work non-commercially, and license their derivative works on different terms, provided the original work is properly cited and the use is non-commercial. See: http://creativecommons.org/licenses/by-nc/4.0/
\end{abstract}

Email alerting Receive free email alerts when new articles cite this article. Sign up in the service box at the top right corner of the online article.

Topic
Collections

Articles on similar topics can be found in the following collections

Neurology (309)

Rehabilitation medicine (203)

\title{
Notes
}

To request permissions go to:

http://group.bmj.com/group/rights-licensing/permissions

To order reprints go to:

http://journals.bmj.com/cgi/reprintform

To subscribe to BMJ go to:

http://group.bmj.com/subscribe/ 


\title{
EXPLORATION OF SOME PERSONAL FACTORS WITH THE INTERNATIONAL CLASSIFICATION OF FUNCTIONING, DISABILITY AND HEALTH CORE SET FOR STROKE
}

\author{
Guna Berzina, MD¹, Markku Paanalahti, PT, MSc², Åsa Lundgren-Nilsson, OT, PhD² and \\ Katharina S. Sunnerhagen, MD, PhD ${ }^{2}$ \\ From the ${ }^{1}$ Riga Stradinš University, Riga, Latvia and ${ }^{2}$ Institute of Neuroscience and Physiology, University of \\ Gothenburg, Gothenburg, Sweden
}

\begin{abstract}
Objective: The aim of this study was to explore the influence of personal factors (i.e. age, gender, place of residence and time since onset of stroke) on self-perceived functioning and environmental factors, using the International Classification of Functioning, Disability and Health (ICF) Core Set for Stroke (extended version) as a framework.

Design: Cross-sectional study.

Participants: A total of 243 community-dwelling persons (53\% men) with prior stroke (6 months to 13 years) with a mean age of 68 years (age range 24-95 years).

Methods: Regression analysis of 4 personal factors (age, gender, place of residence, and time since onset of stroke) was used to explore their influence on different components, domains and categories of functioning and environmental factors, evaluated with the extended version of the Comprehensive ICF Core Set for Stroke.

Results: The personal factors had statistically significant predictive values for almost all the categories, domains and components of functioning and environmental factors examined in this study. These factors influence self-perceived functional outcome and environmental factors in terms of being barriers or facilitators in various ways.

Conclusion: Personal factors, such as age, gender, place of residence and time since onset of stroke, influence self-perceived functioning and environmental factors.
\end{abstract}

Key words: ICF; personal factors; stroke.

J Rehabil Med 2013; 45: 609-615

Correspondence address: Katharina Stibrant Sunnerhagen, Rehabiliation Medicine, University of Gothenburg, 41345 Göteborg, Sweden.E-mail: ks.sunnerhagen@neuro.gu.se

Accepted Jan 29, 2013; Epub ahead of print Jun 10, 2013

\section{INTRODUCTION}

According to the World Health Organization (WHO), approximately 15 million people (1) have a stroke each year, defined as acute neurological dysfunction of vascular origin with sudden or rapid occurrence of symptoms and signs corresponding to the involvement of focal areas in the brain (2). Of these, 5 million die and another 5 million are left with permanent disability (1).
Among adults, stroke, along with ischaemic heart disease, is a leading cause of both death and disability-adjusted life years (DALY) worldwide $(3,4)$. The capacity and performance of persons with stroke is poorer than in other chronic conditions (5). Furthermore, frequency of stroke, along with other noncommunicable diseases, is predicted to increase, especially in rapidly developing regions (6), and therefore disability will be a growing problem.

Disability is the umbrella term for impairments, activity limitations and participation restrictions, referring to the negative aspects of interaction between an individual and his or her contextual factors (7). Disability following stroke affects all levels of functioning (8-10) and appears not to change significantly over time (11).

Data on all aspects of functioning and disability are important for constructing a thorough picture of persons with different health conditions. However, approaches to measuring disability and data collection methods vary between countries, which influences results (6). The International Classification of Functioning, Disability and Health (ICF) was developed (12) to enable the description not only of disabilities, but also of functioning. However, since the ICF encompasses more than 1,400 categories and is not practical for clinical use, the ICF Core Sets were developed (13). The extended version of the ICF Core Set for Stroke has 166 categories (59 body functions, 11 body structures, 59 activities and participation, and 37 environmental factors) $(10,14)$.

Personal factors (PF) (the particular background of an individual's life and living, comprising features of the individual that are not part of the health condition) (12) play a very important role in a patient's functioning and health (15) and are not yet classified by the ICF (12). It is assumed that PF can influence disability at any level (12). PF represent the differences that will always exist between people (16), and a better understanding of PF may therefore enable improvement in person-centred rehabilitation (17).

The aim of this study was to investigate whether PF, such as age, gender, place of residence and time since onset of stroke, can influence self-perceived functioning and predict barriers and facilitators perceived in dealing with environmental factors in the framework of the ICF for persons in the chronic stage of 
stroke who live in Sweden. The PF selected for study relate to a basic background for living with permanent disability and it is possible to categorize or measure them, compared with factors such as coping styles or social background, which require deeper knowledge and specific measurement instruments.

\section{MATERIAL AND METHODS}

\section{Participants}

Data from 243 persons were included in the study. Inclusion criteria were: diagnosis of stroke (ICD-10 codes I60-I67), clinically determined by specialists at stroke units according to WHO criteria (2) and confirmed by computed tomography (CT); age at least 18 years; having given written informed consent (or consent given by next to kin); time from onset of stroke of at least 6 months. The persons were a convenience sample of those with prior stroke living in the community. They were either former patients of a stroke unit or of a rehabilitation clinic, who were in contact with physical therapists in the community or recruited through a patient organization. The aim was to include people of different ages, with different social situations and levels of impairments.

\section{Methods}

Interviews were carried out between 6 months and 13 years after the onset of stroke, with a mean of 33.3 months. There were 5 interviewers, all of whom were trained prior to the study. Participants were interviewed at home using semi-structured questions based on the extended version of the Comprehensive ICF Core Set for Stroke, which includes 166 categories of second-level classification of the ICF (10). The Core Set was completed using all the information received and the researcher's impressions of the interviewed patient.

The study conformed to the ethical principles of the Declaration of Helsinki and was approved by the ethics committee of the University of Gothenburg (numbers T129-05/Ad 419-04 and 390-05).

\section{Data analysis}

Statistical analyses were carried out using SPSS (version 20.0). Descriptive statistics were used for demographic and clinical characteristics of the study population. The qualifier scale of the ICF categories was dichotomized to avoid analysing data that would not represent actual changes in components of the ICF. The qualifier 0 (no problem) was maintained for body functions and structures and activities and participation, qualifiers $1-4$ were re-coded to 1 (problem), response option 8 (not specified) was treated as missing, and response option 9 (not applicable) was re-coded to 0 (no problem). For facilitators of environmental factors, qualifiers 1-4 (facilitators) recoded as 1,0 (neither/nor) were maintained, response option 8 (not specified) was treated as missing, and response options 9 (not applicable) and -1 to -4 (barriers) were re-coded as 0 (neither/nor). For barriers of environmental factors, qualifiers -1 to -4 (barriers) recoded as 1,0 (neither/ nor) was maintained, response option 8 (not specified) was treated as missing, and response option 9 (not applicable) and 1-4 (facilitators) were re-coded as 0 (neither/nor). The problems were counted under different components of functioning, and facilitators and barriers were counted according to the domains of environmental factors included in the extended ICF Core Set for Stroke.

Table I. Baseline characteristics of study population

\begin{tabular}{|c|c|c|c|}
\hline Characteristics & $\begin{array}{l}\text { Males } \\
(n=129,53.1 \%)\end{array}$ & $\begin{array}{l}\text { Females } \\
(n=114,46.9 \%)\end{array}$ & $\begin{array}{l}\text { Total } \\
(n=243,100 \%)\end{array}$ \\
\hline \multicolumn{4}{|l|}{ Age, years } \\
\hline Mean (min-max) & $67.7(31-92)$ & $71.3(24-95)$ & $69.4(24-95)$ \\
\hline Median & 68 & 74 & 71 \\
\hline IQR & $60.2-77$ & $63-83$ & $62-80$ \\
\hline \multicolumn{4}{|l|}{ Time since onset of stroke, months } \\
\hline Mean (min-max) & $33.9(6-144)$ & $32.7(6-157)$ & $33.3(6-157)$ \\
\hline Median & 18 & 12 & 14 \\
\hline IQR & $12-42.5$ & $11-46$ & $12-44$ \\
\hline \multicolumn{4}{|l|}{ Place of residence, $n(\%)$} \\
\hline Country & $37(28.7)$ & $30(26.3)$ & 67 (27.6) \\
\hline City & $92(71.3)$ & $84(73.7)$ & $176(72.4)$ \\
\hline \multicolumn{4}{|l|}{ Diagnosis, ICD-10, $n(\%)$} \\
\hline $\mathrm{I} 60$ & $7(5.4)$ & $7(6.1)$ & $14(5.8)$ \\
\hline $\mathrm{I} 61$ & $19(14.7)$ & $7(6.1)$ & $26(10.7)$ \\
\hline $\mathrm{I} 63$ & $70(54.3)$ & $85(74.6)$ & $155(63.8)$ \\
\hline I64 & $33(25.6)$ & $15(13.2)$ & $48(19.8)$ \\
\hline \multicolumn{4}{|l|}{ Affected side of body, $n(\%)$} \\
\hline None & $8(6.2)$ & $12(10.5)$ & $20(8.2)$ \\
\hline Right & $40(31.0)$ & $39(34.2)$ & $79(32.5)$ \\
\hline Left & $66(51.2)$ & $52(45.6)$ & $118(48.6)$ \\
\hline Both & $7(5.4 \%)$ & $6(5.3)$ & $13(5.3)$ \\
\hline No data & $8(6.2)$ & $5(4.4)$ & $13(5.3)$ \\
\hline \multicolumn{4}{|l|}{ Modified Rankin scale, $n(\%)$} \\
\hline 0 - no disability & $5(3.9)$ & $5(4.4)$ & $10(4.1)$ \\
\hline $1-$ no significant disability & $35(27.1)$ & $20(17.5)$ & $55(22.6)$ \\
\hline 2 -slight disability & $36(27.9)$ & $32(28.1)$ & $68(28.0)$ \\
\hline 3 - moderate disability & $25(19.4)$ & $30(26.3)$ & $55(22.6)$ \\
\hline 4 - moderately severe disability & $25(19.4)$ & $25(21.9)$ & $50(20.6)$ \\
\hline 5 - severe disability & $2(1.5)$ & $1(0.9)$ & $3(1.2)$ \\
\hline No data & $1(0.8)$ & $1(0.9)$ & $2(0.8)$ \\
\hline
\end{tabular}

IQR: interquartile range; ICD-10: International Classification of Diseases $10^{\text {th }}$ revision. 
The same independent variables were used in both the standard multiple regression analysis and the direct logistic regression analysis: age, gender, place of residence (rural or city) and time since onset of stroke. Preliminary analyses were conducted to assess the assumptions of normality, linearity, multicollinearity and homoscedasticity, to ensure that they are adequately fulfilled.

Standard multiple regression was used to assess the ability of selected factors to predict the number of problems in functioning (in the components of body functions and activities and participation) and the number of barriers and facilitators in environmental factors divided into 5 domains ("products and technology"; "natural environment and human rights"; "support and relationships"; "attitudes"; and "services, systems and policies").

Direct logistic regression was used to assess the impact of PF on the perception of selected components of activities and participation and environmental factors in the context of the ICF: "Moving around in different locations" (d469); "Toileting" (d530); "Dressing" (d540); "Doing housework" (d640); "Recreation and leisure" (d920); "Physical geography" (e210); and "Immediate family" (e310). These domains were selected on the basis of their properties for reflecting the need for assistance, previous reports of their being common problems (18-20), and according to clinical judgment.

\section{RESULTS}

The majority of the study population (176 subjects $(72.4 \%)$, mean age 69.4 years, 95 males (52\%)) lived in the city. Sixtyseven subjects (27.6\%), mean age 73.5 years, 37 males $(55 \%)$, lived in rural settings. The baseline characteristics of the study population are shown in Table I.

The most commonly reported problems of functioning were related to mobility, but visual and memory problems were also common (Table II). Relationships with other human beings were important as facilitators (Table II). "Physical geography" (e210), along with "design, construction and building products and technology of building for public use", were the most common barriers (Table II). Descriptive statistics for 12 outcome variables used in the multiple linear regression analysis are shown in Table III, and for 7 outcome variables used in the direct logistic regression analysis in Table V.

Higher age indicated a greater number of problems in functioning. Age also had an influence on most of the areas in the environmental factors. Reports of restrictions in "activities and participation" were more typical in older patients (Tables IV and VI). Time since onset was found to be a factor that influences "activities and participation" and from "environmental factors", the perception of attitudes was influenced (Table IV). Living in a rural setting was associated with perceiving facilitators in "natural environment and human-made changes in the environment". On the other hand, those who lived in the city reported facilitators in "support and relationships" and "attitudes" to a higher degree than those who lived in a rural setting (Tables IV and VI). The results of the complete analyses of the regression analyses are shown in Tables IV and VI, where only independent variables with a $p$-value of less than 0.1 are included. The beta value in Tables IV and VI is reported for the model including all $4 \mathrm{PF}$.
Table II. Commonly reported problems of functioning and facilitators and barriers of environmental factors

\begin{tabular}{|c|c|c|}
\hline & & $n(\%)$ \\
\hline \multicolumn{3}{|c|}{ Body functions } \\
\hline b730 & Muscle power functions & $165(67.9)$ \\
\hline b455 & Exercise tolerance functions & $147(60.5)$ \\
\hline b770 & Gait pattern functions & $143(58.8)$ \\
\hline b210 & Seeing functions & $134(55.1)$ \\
\hline b144 & Memory functions & $125(51.4)$ \\
\hline b740 & Muscle endurance functions & $118(48.6)$ \\
\hline b130 & Energy and drive functions & $114(46.9)$ \\
\hline b755 & Involuntary movement reaction functions & $106(43.6)$ \\
\hline b710 & Mobility of joint functions & $106(43.6)$ \\
\hline b760 & Control of voluntary movement functions & $98(40.3)$ \\
\hline b735 & Muscle tone functions & $85(35)$ \\
\hline b140 & Attention functions & $81(33.3)$ \\
\hline b280 & Sensation of pain & $78(32.1)$ \\
\hline b134 & Sleep functions & $77(31.7)$ \\
\hline b235 & Vestibular functions & $76(31.3)$ \\
\hline
\end{tabular}

Activities and participation

d455 Moving around

$205(84.4)$

d845 Acquiring, keeping and terminating a job $183(75.3)$

d450 Walking

d850 Remunerative employment

d460 Moving around in different locations

d640 Doing housework

d465 Moving around using equipment

d855 Non-remunerative employment

d230 Carrying out daily routine

d475 Driving

d430 Lifting and carrying objects

d240 Handling stress and other psychosocial demands

$181(74.5)$

$169(69.5)$

$166(68.3)$

$166(68.3)$

$159(65.4)$

$154(63.4)$

$153(63)$

$153(63)$

$147(60.5)$

$143(58.8)$

$132(54.3)$

$130(53.5)$

d445 Hand and arm use

d920 Recreation and leisure

$130(53.5)$

Body structures

s110 Structure of brain

s750 Structure of lower extremity

s730 Structure of upper extremity

s410 Structure of cardiovascular system

s720 Structure of shoulder region

Environmental factors as barriers

e150 Design, construction and building products and technology of buildings for public use

e210 Physical geography

e155 Design, construction and building products and technology of buildings for private use

e250 Sound

$97(39.9)$

$78(32.1)$

$68(28)$

$54(22.2)$

$46(18.9)$

$23(9.5)$

$20(8.2)$

$19(7.8)$

$18(7.4)$

$17(7)$

e450 Individual attitudes of health professionals

$193(79.4)$

e310 Immediate family

e320 Friends

e315 Extended family

e355 Health professionals

$173(71.2)$

$149(61.3)$

$149(61.3)$

e325 Acquaintances, peers, colleagues, neighbours, and 118 (48.6) community members

e110 Products or substances for personal consumption

e120 Products and technology for personal indoor and outdoor mobility and transportation

e580 Health services, systems and policies

$113(46.5)$

$113(46.5)$

$113(46.5)$

e410 Individual attitudes of immediate family members

e540 Transportation services, systems and policies

e570 Social security services, systems and policies
$112(46.1)$

$106(43.6)$

$106(43.6)$ 
Table III. Descriptive statistics for outcome variables used in the multiple linear regression analysis

\begin{tabular}{|c|c|c|c|c|c|c|c|c|c|}
\hline & \multicolumn{3}{|c|}{ Males $(n=129)$} & \multicolumn{3}{|c|}{ Females $(n=114)$} & \multicolumn{3}{|c|}{ Total $(n=243)$} \\
\hline & Mean & Median & IQR & Mean & Median & IQR & Mean & Median & IQR \\
\hline Sum of problems in body functions $(0-59)$ & 12.6 & 12 & $7-16$ & 15.2 & 14 & $10-18$ & 13.8 & 13 & $8-17$ \\
\hline Sum of problems in activities and participation $(0-59)$ & 19.6 & 18 & $10-27$ & 22.4 & 21.5 & $13.8-30.2$ & 20.9 & 20 & $12-29$ \\
\hline \multicolumn{10}{|l|}{ Products and technology $(0-8)$} \\
\hline Facilitators & 1.6 & 1 & $0-3$ & 2.2 & 2.0 & $0.8-4$ & 1.9 & 2 & $0-3$ \\
\hline Barriers & 0.2 & 0 & 0 & 0.3 & 0 & 0 & 0.3 & 0 & 0 \\
\hline \multicolumn{10}{|c|}{ Natural environment and human-made changes to environment $(0-3)$} \\
\hline Facilitators & 0.2 & 0 & 0 & 0.2 & 0 & 0 & 0.2 & 0 & 0 \\
\hline Barriers & 0.2 & 0 & 0 & 0.2 & 0 & 0 & 0.2 & 0 & 0 \\
\hline \multicolumn{10}{|l|}{ Support and relationships $(0-7)$} \\
\hline Facilitators & 3.7 & 4 & $2-5$ & 3.8 & 4 & $3-5$ & 3.78 & 4 & $3-5$ \\
\hline Barriers & 0.2 & 0 & 0 & 0.1 & 0 & 0 & 0.2 & 0 & 0 \\
\hline \multicolumn{10}{|l|}{ Attitudes (0-9) } \\
\hline Facilitators & 2.4 & 1 & $0-4$ & 1.7 & 1 & $0-3$ & 2.1 & 1 & $0-3$ \\
\hline Barriers & 0.4 & 0 & 0 & 0.3 & 0 & 0 & 0.5 & 0 & 0 \\
\hline \multicolumn{10}{|l|}{ Services, systems and policies $(0-10)$} \\
\hline Facilitators & 2.2 & 1 & $0-4$ & 3.1 & 3 & $1-5$ & 2.6 & 2 & $0-4$ \\
\hline Barriers & 0.4 & 0 & 0 & 0.2 & 0 & 0 & 0.3 & 0 & 0 \\
\hline
\end{tabular}

IQR: interquartile range.

\section{DISCUSSION}

These results suggest that $\mathrm{PF}$, such as age, gender, place of residence and time since onset of stroke, can influence self-perceived functioning and predict barriers and facilitators perceived in dealing with environmental factors defined in the framework of the ICF. Age and gender as socio-demographic environmental factors are mentioned in the definition of $\mathrm{PF}$ in the framework of the ICF. Although they are not classified in the ICF, they may influence the domains, as shown in this study. However, factors such as place of residence and time since onset are not mentioned in a review dealing with PF (17), although they are not classified under any other components of the ICF.

The PF model chosen for this study showed an impact on functioning and environmental factors. The 2 highest $\mathrm{R}^{2}$ values in this model were for environmental factors (facilitators of "products and technology" and "support and relationships") and number of restrictions in "activities and participation". All other groups analysed also showed statistically significant predictive values. These results may be due to a separation of different domains of environmental factors (because of their diversity), but problems reported in "body functions" and "activities and participation" were counted together under each of these components. Nevertheless, these results are supported by other studies in terms of emphasizing that modifying environmental factors can be beneficial for stroke patients in the chronic phase, while approaches at other levels of individuals' problems are more likely to fail to achieve any satisfactory goal (21-23).

"Physical geography" and "design, construction and building products and technology of building for public use" were

Table IV. Results of standard multiple regression analysis

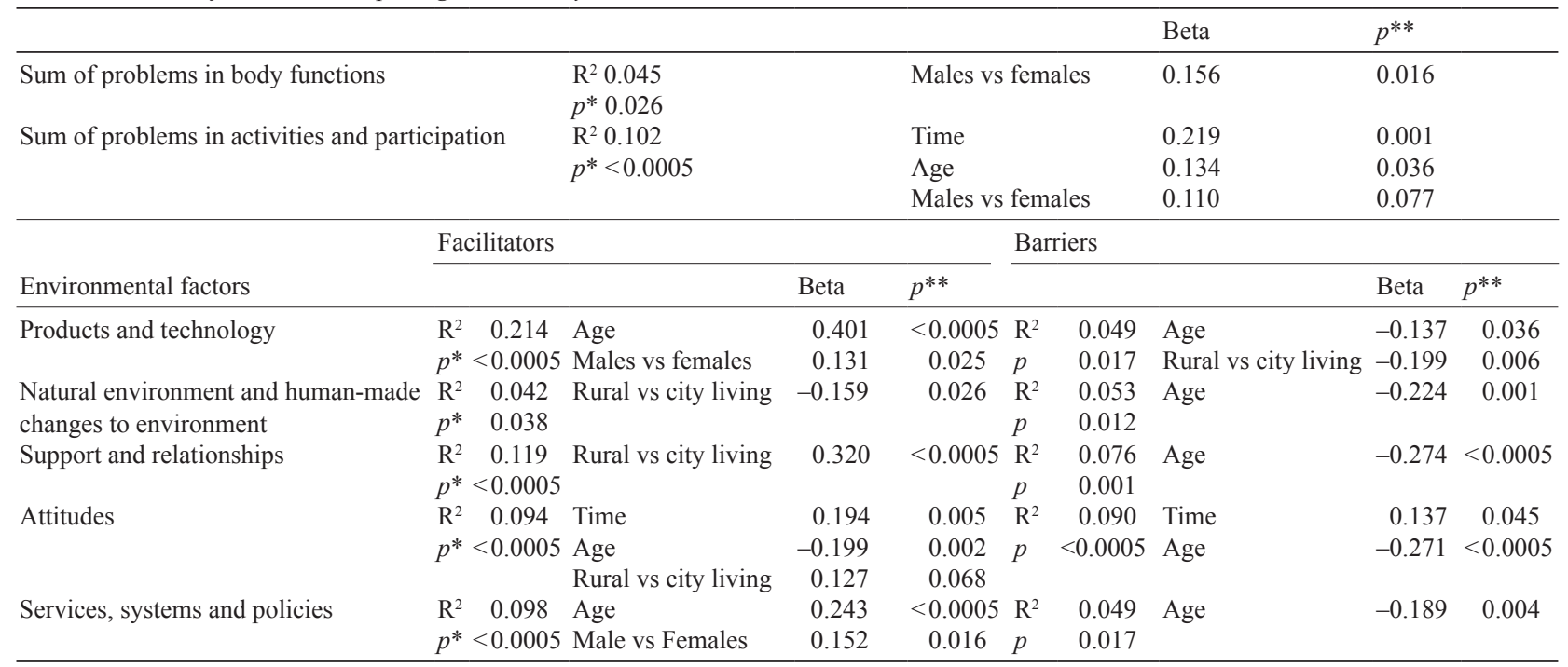

*statistical significance of the model; **statistical significance of each variable of the model. 
Table V. Descriptive statistics for 7 outcome variables used in the direct logistic regression analysis (5 items of "activities and participation" and 2 of "environmental factors")

\begin{tabular}{|c|c|c|c|c|}
\hline \multirow{2}{*}{$\begin{array}{l}\text { ICF } \\
\text { code }\end{array}$} & \multirow[b]{2}{*}{ ICF category title } & \multirow{2}{*}{$\begin{array}{l}\text { Males } \\
(n=129) \\
n\end{array}$} & \multicolumn{2}{|c|}{$\begin{array}{l}\text { Females Total } \\
(n=114)(n=243)\end{array}$} \\
\hline & & & $n$ & $n$ \\
\hline $\mathrm{d} 460$ & Moving around in different locations & 81 & 85 & 166 \\
\hline $\mathrm{d} 530$ & Toileting & 32 & 24 & 56 \\
\hline d5 540 & Dressing & 49 & 47 & 96 \\
\hline d640 & Doing housework & 81 & 85 & 166 \\
\hline d920 & Recreation and leisure & 64 & 66 & 130 \\
\hline \multirow[t]{3}{*}{ e210 } & Physical geography' & & & \\
\hline & Facilitators & 2 & 3 & 5 \\
\hline & Barriers & 11 & 12 & 23 \\
\hline \multirow[t]{3}{*}{ e 310} & Immediate family & & & \\
\hline & Facilitators & 101 & 92 & 193 \\
\hline & Barriers & 4 & 2 & 6 \\
\hline
\end{tabular}

the most commonly recognized barriers, notwithstanding that neither reached the $10 \%$ threshold in this study. These results are unexpected for the category "physical geography", firstly because of the hilly characteristics of the region in which most of the study population lived and, secondly, because the patients in this study mainly come from the same part of Sweden as in the study of Algurén et al. (20), which reported different results. In Algurén et al.'s study of self-reported changes in barriers and facilitators of environmental factors in a similar population of stroke patients in Sweden, 3 months after the stroke more than half of the patients reported that "physical geography" was a problem. However, this cohort of patients had lived longer with their condition after the stroke and, as the environment is persistent and not changeable, after a while patients no longer recognize it as a problem. New experiences and changes in expectations during the post-acute period of stroke can lead to reprioritization, recalibration and reconceptualization, called response shift, of a set of problems that a person meets in his/ her daily life. This, at least, seems to be implied in changes in self-perceived physical function among stroke patients (24).

Seven selected categories were analysed in this study: 5 in the components of "activities and participation" and 2 in environmental factors. The model of PF was found to have highly significant relations to all 5 domains of "activities and participation". For environmental factors, this model was seen to be significant only for barriers in "physical geography" and facilitators for "immediate family", which is understandable, since both "immediate family" as a barrier and "physical geography" as a facilitator are considered only in exceptional cases.

Although this model of PF showed an influence of all the components, domains and categories that were used for analysis, the influence of each single factor and the interaction of these factors differed widely between different components, domains and categories. For example, the domain "moving around in different locations" was found to be influenced only by age, whereas "doing housework" was influenced by a combination of all the factors studied. Also, explained variance between models differed and was rather low for components such as "body functions" and "natural environment and humanmade changes to environment". This result is not unexpected, as most variance in functioning is explained by underlying health condition and its impairments.

Age was found to have the greatest influence of all the components, domains and categories of the ICF studied. While the most common problems in "body functions" and "activities and participation" were related to mobility, components of functioning reach beyond that. Age was shown to influence a number of problems and all of the chosen categories of "activities and participation" and almost all the domains of

Table VI. Results of direct logistic analysis for 7 chosen domains of the ICF (5 items of "activities and participation" and 2 of "environmental factors")

\begin{tabular}{|c|c|c|c|c|c|c|c|c|c|}
\hline \multirow{2}{*}{$\begin{array}{l}\text { ICF } \\
\text { code }\end{array}$} & \multirow{2}{*}{\multicolumn{2}{|c|}{ ICF category title }} & \multirow[b]{2}{*}{$p^{*}$} & & \multirow[b]{2}{*}{ Beta } & \multirow[b]{2}{*}{$p^{* *}$} & \multirow[b]{2}{*}{ OR } & \multicolumn{2}{|c|}{$95 \% \mathrm{CI}$ for OR } \\
\hline & & & & & & & & Lower & Upper \\
\hline $\mathrm{d} 460$ & \multirow{2}{*}{\multicolumn{2}{|c|}{$\begin{array}{l}\text { Moving around in different locations } \\
\text { Toileting }\end{array}$}} & $<0.0005$ & Age & 0.054 & 0.000 & 1.056 & 1.031 & 1.082 \\
\hline \multirow[t]{4}{*}{$\mathrm{d} 530$} & & & $<0.0005$ & Time & 0.011 & 0.033 & 1.011 & 1.001 & 1.021 \\
\hline & & & & Age & 0.047 & 0.002 & 1.048 & 1.017 & 1.080 \\
\hline & & & & Males vs females & -0.583 & 0.090 & 0.558 & 0.285 & 1.094 \\
\hline & & & & Rural vs city living & -0.817 & 0.033 & 0.442 & 0.208 & 0.938 \\
\hline \multirow[t]{3}{*}{ d5 540} & Dressing & & $<0.0005$ & Time & 0.010 & 0.049 & 1.010 & 1.000 & 1.019 \\
\hline & & & & Age & 0.036 & 0.003 & 1.013 & 1.013 & 1.062 \\
\hline & & & & Rural vs city living & -1.038 & 0.003 & 0.354 & 0.177 & 0.709 \\
\hline \multirow[t]{4}{*}{ d640 } & Doing housework & & $<0.0005$ & Time & 0.018 & 0.022 & 1.018 & 1.003 & 1.033 \\
\hline & & & & Age & 0.036 & 0.003 & 1.036 & 1.013 & 1.060 \\
\hline & & & & Males vs females & 0.660 & 0.043 & 1.935 & 1.021 & 3.669 \\
\hline & & & & Rural vs city living & -1.036 & 0.013 & 0.241 & 0.078 & 0.740 \\
\hline \multirow[t]{2}{*}{ d920 } & Recreation and leisure & & $<0.0005$ & Age & 0.029 & 0.008 & 1.029 & 1.007 & 1.052 \\
\hline & & & & Rural vs city living & -1.027 & 0.023 & 0.358 & 0.148 & 0.867 \\
\hline \multirow[t]{2}{*}{$\mathrm{e} 210$} & Physical geography’ & Facilitators & 0.054 & & & & & & \\
\hline & & Barriers & 0.016 & Rural vs city living & -1.519 & 0.004 & 0.219 & 0.079 & 0.608 \\
\hline \multirow[t]{3}{*}{ e310 } & Immediate family & Facilitators & 0.001 & Age & 0.039 & 0.022 & 1.042 & 1.040 & 1.075 \\
\hline & & & & Rural vs city living & 2.110 & 0.000 & 8.251 & 2.860 & 23.801 \\
\hline & & Barriers & 0.470 & & & & & & \\
\hline
\end{tabular}

*statistical significance of the model; **statistical significance of each variable of the model.

ICF: International Classification of Functioning, Disability and Health; OR: odds ratio; CI: confidence interval. 
environmental factors, except for the reporting of a "physical geography" as a barrier. Reporting restrictions in "activities and participation" was more typical in older patients, while reporting barriers in "natural environment and human-made changes to environment", "support and relationships" and both facilitators and barriers in "products and technology" and "attitudes" were more common among younger patients. Several studies have shown the importance of age as a factor in the functional outcome of stroke (25-27).

Some studies explain gender differences in stroke outcome by a greater mean age in women who have a first-ever stroke $(28,29)$ and by a lower level of consciousness on admission (29). However, there are findings in studies based on the Swedish stroke population that suggest that there are certain differences that might be explained by biological, epidemiological and clinical differences (30). It is worth mentioning that most of the differences considered to be gender-specific are assessed using self-perceived questionnaires $(31,32)$. In our study, gender has shown some relation to functioning, where more problems are reported by males, unlike the studies mentioned above (28-32) in which men had been prone to have a better outcome. One possible explanation for this association of "doing housework" and gender, where every woman reported this as a problem, while only two men reported the same, could be that gender plays a role in social distinction.

Rural and urban disparities have been underlined for stroke management (33) because of the accessibility of healthcare (34), although there is evidence that differences in functional outcome are related to receiving organized stroke care rather than any other reason (35). Still, according to data in the Swedish Stroke register, nearly all persons who require treatment in a stroke unit do receive that treatment (36). It may be thought that living in a rural region or in a city makes a great difference in daily living, society and the physical environment, and can offer unique previous experience that can lead to a different treatment of a person's condition, skills and environment. This can greatly affect functioning at different levels (37). Nevertheless, having facilitators in "natural environment and human-made changes in environment" was reported more often by those living in a rural setting, but facilitators in "support and relationships" and "attitudes" reported by those living in a city is not an expected result. Categories in "activities and participation" ("toileting", "dressing", "doing housework" and "recreation and leisure") were influenced by place of residence, indicating that those who lived in the city more often recognized this as a problem, which also indicates a diversity that is related to subjective reasons (such as self-image and demands) rather than to objective barriers in the environment. The odds of perceiving "physical geography" as a barrier was 4.6 times higher among people who lived in the city. This phenomenon could be explained by differences in the objective geography of the place of residence, or by different personal attitudes to the environment. "Immediate family" as a facilitator was mentioned much more often by those who lived in a rural setting. In rural areas, a person could be much more closely connected to the family than may be the case in the city when the family does not live in the near vicinity or where other care providers are available.

Time since onset was found to be a factor that influences only two groups analysed in this study, where the longer the time that had elapsed since the stroke event, the smaller was the possibility to recognize "activities and participation" as a problem or "attitudes" as facilitators or barriers. However, this factor showed some influence on "dressing", "toileting" and "doing housework", which tended to increase with time. Most of the existing evidence shows that the most effective time for rehabilitation is the first 6 months after the stroke, although it is reported that some patients can also gain skills after this period (38). As mentioned above, there is some evidence that the domains that persons with disabilities report as being problems can change with time $(24,39)$. The results of this study suggest that time since onset of stroke of longer than 6 months can influence activities and participation. As this is a cross-sectional study, there is a probability that this is either due to a shift in perception or to results reported by chance.

Participants were included in this study using convenience sampling for people who were connected to rehabilitation facilities and had received rehabilitation at some time after their stroke. The study population was approximately 5 years younger than the stroke population in Sweden at that time (40). Both of these facts indicate limitations in the representativeness of the population. A further limitation is that, for the ICF, qualifiers are intended to denote the extent of the problem, but this does not satisfy the criteria for reliable measurement. To avoid analysing data that would not represent actual changes in components of the ICF, the data were dichotomized. Thus, the results show the possibility of having or of not having a problem in a certain domain of functioning by the facilitators or barriers that are reported, or of having a number of problems below these levels. This does not say anything about the extent of the problem. Country of birth, as an aspect of PF, was expected to play a role in the perception of functioning and environmental factors. The number of persons born outside Sweden was lower in this cohort than one would expect and was insufficient for reliable statistical analysis.

All 4 of the socio-demographic factors selected in this study contribute to the conditions that make up individual experience based on assigned social roles. These were shown to have an influence on functioning and environmental factors. There are probably many other PF, that have not yet been investigated, that will be found to play an important role in functioning and in different aspects of rehabilitation. The identification of more factors will enhance possibilities for improving patient-centred care.

In conclusion, $\mathrm{PF}$, such as age, gender, place of residence and time since onset of stroke, have a predictive value for functioning and environmental factors in the chronic phase after stroke. These influence self-perceived functional outcome and environmental factors in terms of being barriers or facilitators. Further research is required to elucidate the interaction between different parts of the ICF (functioning and contextual factors), and in particular to investigate other PF that may have a signifficant impact on functioning. 


\section{REFERENCES}

1. World Health Organization. The atlas of heart disease and stroke. Geneva: World Health Organization; 2004.

2. Stroke-1989. Recommendations on stroke prevention, diagnosis, and therapy. Report of the WHO Task Force on Stroke and other Cerebrovascular Disorders. Stroke 1989; 20: 1407-1431.

3. Lopez AD, Mathers CD, Ezzati M, Jamison DT, Murray CJ. Global and regional burden of disease and risk factors, 2001: systematic analysis of population health data. Lancet 2006; 367: 1747-1757.

4. Strong K, Mathers C, Bonita R. Preventing stroke: saving lives around the world. Lancet Neurol 2007; 6: 182-187.

5. Leonardi M, Mateos A, Bichenbach J, Raggi A, Fransceuti C, Franco M, et al. MHDADIE background document on disability prevalence across different diseases and EU countries. 2009. Measuring Health and Disability in Europe, Milan. Available from: www.mhadie.it.

6. World Health Organization. World report on disability. Geneva: World Health Organization; 2011.

7. Leonardi M, Bickenbach J, Ustun TB, Kostanjsek N, Chatterji S. The definition of disability: what is in a name? Lancet 2006; 368: 1219-1221.

8. Jorgensen HS, Nakayama H, Raaschou HO, Vive-Larsen J, Stoier $\mathrm{M}$, Olsen TS. Outcome and time course of recovery in stroke. Part I: Outcome. The Copenhagen Stroke Study. Arch Phys Med Rehabil 1995; 76: 399-405.

9. Danielsson A, Willen C, Sunnerhagen KS. Is walking endurance associated with activity and participation late after stroke? Disabil Rehabil 2011; 33: 2053-2057.

10. Glassel A, Coenen M, Kollerits B, Cieza A. Validation of the extended ICF core set for stroke from the patient perspective using focus groups. Disabil Rehabil 2012; 34: 157-166.

11. White JH, Alston MK, Marquez JL, Sweetapple AL, Pollack MR, Attia J, et al. Community-dwelling stroke survivors: function is not the whole story with quality of life. Arch Phys Med Rehabil 2007; 88: 1140-1146.

12. International Classification of Functioning, Disability and Health. Geneva: World Health Organization; 2001.

13. Cieza A, Ewert T, Ustun TB, Chatterji S, Kostanjsek N, Stucki G. Development of ICF Core Sets for patients with chronic conditions. J Rehabil Med 2004; Suppl 44: 9-11.

14. Starrost K, Geyh S, Trautwein A, Grunow J, Ceballos-Baumann A, Prosiegel M, 1. Interrater reliability of the extended ICF core set for stroke applied by physical therapists. Phys Ther 2008; 88: 841-851.

15. Geyh S, Cieza A, Schouten J, Dickson H, Frommelt P, Omar Z, et al. ICF Core Sets for stroke. J Rehabil Med 2004: Suppl 44: 135-141.

16. Gladman JR. The international classification of functioning, disability and health and its value to rehabilitation and geriatric medicine. J Chin Med Assoc 2008; 71: 275-278.

17. Geyh S, Peter C, Muller R, Bickenbach JE, Kostanjsek N, Ustun $\mathrm{BT}$, et al. The personal factors of the International Classification of Functioning, Disability and Health in the literature - a systematic review and content analysis. Disabil Rehabil 2011; 33: 1089-1102.

18. Quintas R, Cerniauskaite M, Ajovalasit D, Sattin D, Boncoraglio G, Parati EA, et al. Describing functioning, disability, and health with the International Classification of Functioning, Disability, and Health Brief Core Set for Stroke. Am J Phys Med Rehabil 2012; 9113 Suppl 1: S14-S21.

19. Snogren M, Sunnerhagen KS. Description of functional disability among younger stroke patients: exploration of activity and participation and environmental factors. Int J Rehabil Res 2009; 32: 124-131.

20. Alguren B, Lundgren-Nilsson A, Sunnerhagen KS. Facilitators and barriers of stroke survivors in the early post-stroke phase. Disabil Rehabil 2009; 31: 1584-1591.

21. Goljar N, Burger H, Vidmar G, Leonardi M, Marincek C. Measuring patterns of disability using the International Classification of Functioning, Disability and Health in the post-acute stroke rehabilitation setting. J Rehabil Med 2011; 43: 590-601.

22. Alguren B, Fridlund B, Cieza A, Sunnerhagen KS, Christensson L. Factors associated with health-related quality of life after stroke: a 1-year prospective cohort study. Neurorehabil Neural Repair 2012; 26: 266-274.

23. Bouffioulx E, Arnould C, Thonnard JL. Satisfaction with activity and participation and its relationships with body functions, activities, or environmental factors in stroke patients. Arch Phys Med Rehabil 2011; 92: 1404-1410.

24. Barclay-Goddard R, Lix LM, Tate R, Weinberg L, Mayo NE. Health-related quality of life after stroke: does response shift occur in self-perceived physical function? Arch Phys Med Rehabil 2011; 92: 1762-1769.

25. Carod-Artal FJ, Medeiros MS, Horan TA, Braga LW. Predictive factors of functional gain in long-term stroke survivors admitted to a rehabilitation programme. Brain Inj 2005; 19: 667-673.

26. Carod-Artal FJ, Egido JA. Quality of life after stroke: the importance of a good recovery. Cerebrovasc Dis 2009; 27 Suppl 1: 204-214.

27. Knoflach M, Matosevic B, Rucker M, Furtner M, Mair A, Wille $\mathrm{G}$, et al. Functional recovery after ischemic stroke - a matter of age: data from the Austrian Stroke Unit Registry. Neurology 2012; 78: 279-285.

28. Kelly-Hayes M, Beiser A, Kase CS, Scaramucci A, D’Agostino RB, Wolf PA. The influence of gender and age on disability following ischemic stroke: the Framingham study. J Stroke Cerebrovasc Dis 2003; 12: 119-126.

29. Eriksson M, Glader EL, Norrving B, Terent A, Stegmayr B. Sex differences in stroke care and outcome in the Swedish national quality register for stroke care. Stroke 2009; 40: 909-914.

30. Roding J, Glader EL, Malm J, Lindstrom B. Life satisfaction in younger individuals after stroke: different predisposing factors among men and women. J Rehabil Med 2010; 42: 155-161.

31. Roding J, Glader EL, Malm J, Eriksson M, Lindstrom B. Perceived impaired physical and cognitive functions after stroke in men and women between 18 and 55 years of age - a national survey. Disabil Rehabil 2009; 31: 1092-1099.

32. Feigin VL, Barker-Collo S, Parag V, Senior H, Lawes CM, Ratnasabapathy Y, et al. Auckland Stroke Outcomes Study. Part 1: Gender, stroke types, ethnicity, and functional outcomes 5 years poststroke. Neurology 2010; 75: 1597-1607.

33. Leira EC, Hess DC, Torner JC, Adams HP Jr. Rural-urban differences in acute stroke management practices: a modifiable disparity. Arch Neurol 2008; 65: 887-891.

34. Rodriguez D, Cox M, Zimmer LO, Olson DM, Goldstein LB, Drew L, et al. Similar secondary stroke prevention and medication persistence rates among rural and urban patients. J Rural Health 2011; 27: 401-408.

35. Cadilhac DA, Kilkenny MF, Longworth M, Pollack MR, Levi CR. Metropolitan-rural divide for stroke outcomes: do stroke units make a difference? Intern Med J 2011; 41: 321-326.

36. Riks Stroke. Riks-Stroke end-of-year report 2010. [Internet] 2011. Available from: http://www.riks-stroke.org/index.php.

37. Corrigan R, McBurney H. Community ambulation: perceptions of rehabilitation physiotherapists in rural and regional communities. Physiother Theory Pract 2012; 28: 10-17.

38. Kwakkel G, Kollen B, Lindeman E. Understanding the pattern of functional recovery after stroke: facts and theories. Restor Neurol Neurosci 2004; 22: 281-299.

39. Thoren-Jonsson AL. Coming to terms with the shift in one's capabilities: a study of the adaptive process in persons with poliomyelitis sequelae. Disabil Rehabil 2001; 23: 341-351.

40. Appelros P, Jonsson F, Asplund K, Eriksson M, Glader EL, Asberg $\mathrm{KH}$, et al. Trends in baseline patient characteristics during the years 1995-2008: observations from Riks-Stroke, the Swedish Stroke Register. Cerebrovasc Dis 2010; 30: 114-119. 